4 nordon 



\section{Rekruttering av kompetanse- arbeidskraft fra tredjeland til Norden}

- Reguleringer, strategier og realiteter

Nana Wesley Hansen, Åsmund Arup Seip og Line Eldring (red.)

TemaNord 2010:536 
Rekruttering av kompetansearbeidskraft fra tredjeland til Norden

- Reguleringer, strategier og realiteter

TemaNord 2010:536

(C) Nordisk Ministerråd, København 2010

ISBN 978-92-893-2054-2

Tryk: Kailow Express ApS

Oplag: 200

Trykt på miljøvenligt papir som opfylder kravene i den nordiske miljøsvanemærkeordning.

Publikationen kan bestilles på www.norden.org/order. Flere publikationer på

www.norden.org/publikationer

Denne rapport er udgivet med finansiel støtte fra Nordisk Ministerråd. Indholdet i rapporten afspejler dog ikke nødvendigvis Nordisk Ministerråds synspunkter, meninger, holdninger eller anbefalinger.

Printed in Denmark

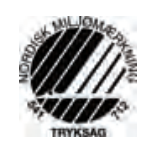

Nordisk Ministerråd

Store Strandstræde 18

1255 København K

Telefon (+45) 33960200

Fax (+45) 33960202

\section{Nordisk Råd}

Store Strandstræde 18

1255 København K

Telefon (+45) 33960400

Fax (+45) 33111870

www.norden.org

\section{Det nordiske samarbejde}

Det nordiske samarbejde er en af verdens mest omfattende regionale samarbejdsformer. Samarbejdet omfatter Danmark, Finland, Island, Norge og Sverige, samt de selvstyrende områder Færøerne, Grønland og Åland.

Det nordiske samarbejde er både politisk, økonomisk og kulturelt forankret, og er en vigtig medspiller i det europæiske og internationale samarbejde. Det nordiske fællesskab arbejder for et stærkt Norden i et stærkt Europa.

Det nordiske samarbejde ønsker at styrke nordiske og regionale interesser og værdier i en global omverden. Fælles værdier landene imellem er med til at styrke Nordens position som en af verdens mest innovative og konkurrencedygtige regioner. 


\section{Innhold}

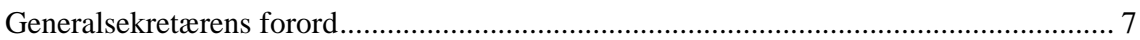

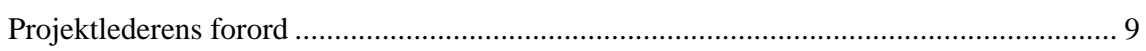

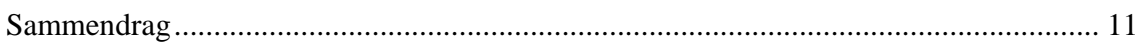

1. Innledning

Line Eldring.....

2. Danmark

Nana Wesley Hansen og Anne Marie Boesen ............................................................ 19

2.1 National lovregulering af arbejdsindvandring fra tredjelande ............................ 19

2.2 Rekruttering og invandring af ingeniører i tal .......................................... 32

2.3 Nationale udfordringer i rekrutteringspolitikken ......................................... 41

Kilder og referencer ................................................................................. 43

3. Finland

Åsmund Arup Seip ...................................................................................... 47

3.1 Nasjonale lovreguleringer av arbeidsinnvandring fra tredjeland ....................... 47

3.2 Rekruttering og innvandring av ingeniører fra tredjeland................................. 52

3.3 Nasjonale utfordringer i arbeidsinnvandringspolitikken .................................. 58

Kilder og referanser............................................................................. 60

4. Island

Nana Wesley Hansen og Anne Marie Boesen ......................................................... 61

4.1 National lovregulering af arbejdsindvandring fra tredjelande ............................ 61

4.2 Rekruttering og indvandring af ingeniører i tal ............................................ 65

4.3 Nationale udfordringer i rekrutteringspolitikken ......................................... 66

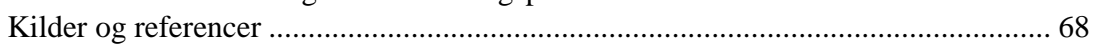

5. Norge

Åsmund Arup Seip .......................................................................................... 69

5.1 Nasjonale lovreguleringer av arbeidsinnvandring fra tredjeland ....................... 69

5.2 Rekruttering og innvandring av ingeniører fra tredjeland............................... 77

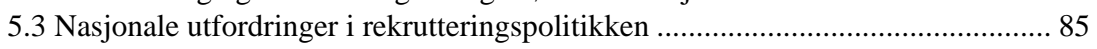

Kilder og referanser............................................................................. 87

6. Sverige

Sofia Murhem och Andreas Dahlkvist ............................................................... 89

6.1 Nationell lagstiftning rörande arbetskraftsinvandring från tredje land ............... 89

6.2 Invandring och rekrytering av ingenjörer från tredje land................................ 98

6.3 Nationella utmaningar för rekryteringspolitiken ......................................... 107

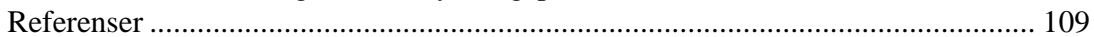

7. Nordiske udfordringer i arbejdsindvandringspolitikken for kvalificeret arbejdskraft Nana Wesley Hansen og Søren Kaj Andersen ............................................................ 111

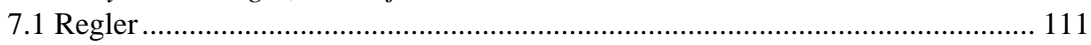

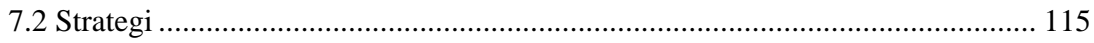

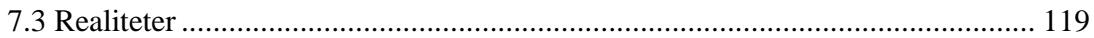

7.4 Regler, strategier og realiteter - en opsummering ............................................ 122

7.5 Andre perspektiver på arbejdsindvandringspolitik ....................................... 124

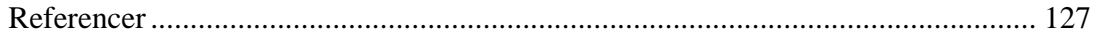





\section{Generalsekretærens forord}

De nordiske lande klarer sig relativt godt i den internationale konkurrence. Skal vi fortsat være konkurrencedygtige på verdensmarkedet fremover kræver det, at vi kan tilvejebringe den kvalificerede arbejdskraft, som vore virksomheder har brug for. Med den demografiske udvikling vil behovet for at tiltrække arbejdskraft udefra vokse. Globaliseringen indebærer imidlertid også en skærpet konkurrence om arbejdskraften, og det øger kravet om at skabe attraktive arbejdsmarkeder i Norden.

Det er derfor helt centralt, at vi i Norden nøje overvejer og samarbejder om, hvordan vi bedst muligt kan tiltrække og rekruttere kvalificeret arbejdskraft fra lande uden for Norden. De nordiske lande har siden EUudvidelsen i 2004 nydt godt af indvandret arbejdskraft fra de nye medlemslande. Men også disse lande rammes efterhånden af mangel på arbejdskraft pga. udvandringen og den demografiske udvikling. Norden må derfor rette søgelyset mod lande uden for EU/EØS.

I dette studie har Nordisk Ministerråd i samarbejde med en lang række organisationer og forskere i Norden valgt at fokusere på indvandring og rekruttering af ingeniører fra lande uden for EU/EØS samt nationale og nordiske udfordringer i arbejdsindvandringspolitikken. Studiet giver en oversigt over de nationale lovreguleringer i Danmark, Finland, Island, Norge og Sverige på dette område og søger at identificere mulige forklaringer på forskellene i indvandringen af højtkvalificeret arbejdskraft blandt de nordiske lande.

Det er mit håb at dette projekt kan bidrage til at styrke det nordiske samarbejde om at øge rekrutteringen af kvalificeret arbejdskraft fra tredjelande til Norden.

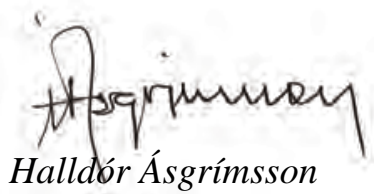

Generalsekretær

Nordisk Ministerråd 



\section{Projektlederens forord}

I denne rapporten presenteres resultatene fra et nordisk samarbeidsprosjekt om rekruttering av kompetansearbeidskraft til Norden fra land utenfor EU/EØS-området. På tross av mye oppmerksomhet rundt rekruttering av kompetansearbeidskraft fra tredjeland, finnes det få systematiske analyser av dette. Vi håper denne rapporten vil bidra til økt kunnskap. En viktig bakgrunn for prosjektet har også vært et ønske om å styrke den nordiske dimensjonen i utviklingen av arbeidsinnvandrings-politikken, og bidra til videreutvikling av samarbeidet mellom de nordiske ingeniørorganisasjonene, relevante arbeidsgiverorganisasjoner og nordiske forskere.

Prosjektet har vært knyttet til Nordisk Ministerråds prosjektvirksomhet innenfor temaet "Den framtida efterfrågan på arbetskraft", og er delvis finansiert gjennom prosjektmidler fra Ministerrådets Arbetsmarknadsutskott. I tillegg har følgende organisasjoner og bedrifter bidratt med finansiering til prosjektet: Dansk Industri (DK), Ingeniørforeningen IDA (DK), Driftingenjörsförbundet i Finland (FI), Nya Ingenjörsförbundet (FI), Teknikens Akademiker-förbund TEK (FI), Tekniska Föreningen i Finland (FI), NITO (NO), Norsk Industri (NO), Tekna (NO), Epsilon AB (S), Svenskt Näringsliv (S) og Sveriges Ingenjörer (S). I tillegg har ingeniørorganisasjonene i Island bidratt med informasjon. Vi vil takke alle sammen for støtten til prosjektet, og ikke minst deres representanter for hjelp med datainnsamling, konstruktive innspill og engasjert deltakelse i seminarer i løpet av prosjektperioden. En spesiell takk til NITO v/Håvard Lismoen som var med på å initiere prosjektet og som har bidratt med koordinering og administrasjon underveis. Tusen takk også til Lars Djernæs fra Nordisk Ministerråd som har fulgt oss gjennom hele prosjektet.

Forsknings- og utredningsarbeidet i prosjektet har vært gjennomført i et samarbeid mellom forskere fra FAOS ved Københavns Universitet (Nana Wesley Hansen, Søren Kaj Andersen og Anne Marie Boesen), Fafo Institutt for Arbeids- og velferdsforskning i Oslo (Åsmund Arup Seip og Line Eldring) og Ekonomisk-historiska institutionen ved Uppsala Universitet (Sofia Murhem og Andreas Dahlkvist). Forskerne utarbeidet et felles opplegg for landanalysene, og har samarbeidet underveis med innspill på tvers av landene. De enkelte forskningsinstitusjonene har hatt ansvaret for rapporteringen fra sine hjemland. I tillegg har forskerne fra FAOS skrevet om Island, og også hatt hovedansvaret for rapportens avsluttende og sammenfattende kapittel. Fafo har rapportert fra Finland, i tillegg til Norge, samt hatt ansvar for prosjektledelse og koordinering av arbeidet. 
Til slutt vil vi takke representantene fra organisasjonene som er nevnt ovenfor for nyttige kommentarer til tidligere utkast av rapporten. Tusen takk også til representanter fra Arbetsmarknadsutskottet og de nasjonale arbeidsdepartementene- og direktoratene, som har bidratt både med informasjon og rapportkommentarer. Det endelige resultatet står imidlertid som vanlig for forskernes egen regning.

Oslo, februar 2010

Line Eldring, prosjektleder 


\section{Sammendrag}

Rapportens tema er rekruttering av kompetansearbeidskraft til Norden fra land utenfor EU/EØS-området. De ulike kapitlene går igjennom nasjonale lovreguleringer i Danmark, Finland, Island, Norge og Sverige, og ser også på utviklingen i regelverket gjennom den siste tiårsperioden. Studien har hatt et særlig fokus innvandring og rekruttering av ingeniører fra tredjeland, samt nasjonale og nordiske utfordringer i arbeidsinnvandringspolitikken.

\section{Danmark}

Siden 2001 har Danmark haft særlig fokus på rekruttering af udenlandsk arbejdskraft. Man har foretaget markante ændringer i de adgangsgivende regler, taget initiativer til at forbedre formidlingen af udenlandsk arbejdskraft og lavet pilot projekt omkring aktiv markedsføring af Danmark i udlandet. Som et tredje ben til strategien er man også påbegyndt initiativer til fastholdelse af arbejdskraften. Arbejdsmarkedets parter har deltaget aktivt i denne udvikling. Tredjelandsborgere med særlige kvalifikationer eller et jobtilbud med et vist lønniveau, kan få særlig nem adgang via en række ordninger. Heriblandt er Positivlisten, Beløbsordningen, og Greencard de tre ordninger, der har spillet den største rolle for rekrutteringen. Der kommer stadig relativt få kvalificerede udlændinge fra tredjelande til Danmark på særordningerne, men tendensen er stigende især på Beløbsordningen og Greencard-ordningen. Det samme gør sig gældende for antallet af ingeniører fra tredjelande. Man har løbende overvåget tilgangen af arbejdskraft, men først med udvidelsen af Arbejdsmarkedsstyrelsens nøgletalssystem i januar 2010, kan man nu overvåge, hvor meget af den udenlandske arbejdskraft, der ankommer, som også vælger at blive og arbejde i Danmark og hvor længe de bliver. Det er dog ikke muligt at sige noget om, hvilke specifikke kompetencer den udenlandske arbejdskraft medbringer på baggrund af det nuværende talmateriale.

\section{Finland}

Finland vedtok en ny utlendingslov i 2004. Regelverket som gjelder innvandring fra tredjeland stiller opp et generelt krav om at det skal foreligge tilbud om arbeid. Det stilles også et krav til arbeidsmarkedsvurdering. Høyt utdannet arbeidskraft får i mange tilfeller oppholdstillatelse med hjemmel i en bestemmelse som ikke krever at det foretas en arbeidsmarkedsvurdering. Et nytt lovforslag fra regjeringen vil avvikle ordningen med arbeidsmarkedsvurdering og gi arbeidsgiver et større ansvar for å dokumentere at arbeidskraften ikke er tilgjengelig innenfor det europeis- 
ke arbeidsmarkedet før det kan ansettes arbeidstakere fra tredjeland. Partene i arbeidslivet støtter i dag forslaget om å avvikle arbeidsmarkedsvurderingen, men arbeidstaker-organisasjonene har understreket viktigheten av å sikre god kontroll med arbeidsforholdene. Verken myndighetene eller ingeniørorganisasjonene har foreslått såkalte Blue Card-ordninger eller drøftet særskilte tiltak for å stimulere innvandring av ingeniører. Innvandringen fra tredjeland til Finland har vært relativt beskjeden, men det finnes ikke tilgjengelig statistikk over innvandringen for ingeniører eller andre yrkesgrupper.

\section{Island}

Det økonomiske opsving i Island, som toppede i midten af 2007, tiltrak en stor mængde udenlandsk arbejdskraft fra især andre europæiske lande. På baggrund af den ekstraordinære arbejdskraftefterspørgsel foretog man i 2008 en revisionen af lovgivningen for arbejdstilladelser, hvor man indførte en ordning for særligt kvalificerede arbejdstagere. For at få arbejdstilladelse skal man have opnået opholdstilladelse. Ophold forudsætter, at der er tale om et konkret jobtilbud, og at det ikke har været muligt at rekruttere national arbejdskraft eller arbejdskraft fra EU/EØS området. Arbejdsdirektoratet kan udstede midlertidig arbejdstilladelse, hvor fagforeningerne skal høres eller den særlige specialist-arbejdstilladelse, der forudsætter en servicekontrakt med en virksomhed i Island.

Island blev imidlertid hårdt ramt af den globale finansielle krise og ledigheden har herefter været stigende. Først på længere sigt, vil efterspørgslen efter arbejdskraft og herunder også ingeniører stige igen.

\section{Norge}

Norge vedtok i 2008 en ny utlendingslov, og har i den forbindelse foretatt endringer i regelverket for arbeidsinnvandring.

For arbeidsinnvandring fra tredjeland gjelder et generelt krav om at det skal foreligge tilbud om arbeid. Det stilles også krav til kompetanse som faglært eller spesialist. Spesialister defineres ut fra en lønnsterskel på NOK 500000 (ca EUR 55 000). Innenfor en kvote på 5 000, kan det gis tillatelser uten at det foreligger en konkret arbeidsmarkedsvurdering.

Med støtte fra arbeidsgiver- og arbeidstakerorganisasjonene har myndighetene forsøkt å forenkle prosedyrene for innvandring. I tråd med en etterspørselsstyrt rekrutteringspolitikk har myndighetene i liten grad drøftet tiltak for særskilte grupper som for eksempel ingeniører.

Det finnes lite statistikk over utenlandske ingeniører i Norge. Foreliggende surveymateriale på bedriftsnivå antyder at det i industrien er mellom $10-15 \%$ av virksomhetene som benytter ingeniører fra tredjeland. 


\section{Sverige}

Den 15 december 2008 infördes en ny lagstiftning rörande arbetskraftsinvandring från tredje land till Sverige. Det nya regelverket medförde en förenkling av tillståndshanteringen för arbetskraftsinvandrare från tredje land genom att Migrationsverket inte längre skulle samråda med Arbetsförmedlingen före beslut. Dessutom innebar den nya lagstiftningen en tydlig liberalisering jämfört med tidigare bestämmelser, bland annat som ett resultat av att bedömningen om det finns behov av att rekrytera arbetskraft från tredje land fördes över till enskilda arbetsgivare och genom borttagandet av tidigare skrivelser som fokuserade på rådande brist som ett villkor för arbetstillstånd. Dock verkar de svenska myndigheterna inte har vidtagit några direkta rekryteringsåtgärder med särskild inriktning på kvalificerad arbetskraft från tredje land.

Även om det står klart att arbetskraftsinvandring från tredje land, generellt såväl som när det gäller ingenjörer, har ökat under de senaste åren är det svårt att uttala sig om vilken inverkan de senaste lagstiftningsförändringarna har haft. Även om det finns statistik att tillgå är det är svårt att uttala sig om konkreta effekter då införandet av de nya reglerna sammanföll med en lågkonjunktur. Dock tycks det som om regelverket haft viss effekt. Uppfattningen på arbetsgivarsidan är att den nya lagstiftningen fungerar bra och att denna bör ses som en positiv förändring. Vissa arbetstagarorganisationer ställer sig dock kritiska till att de fått ta på sig en "myndighetsroll" i den kontrollprocess som genomförs i samband med tillståndsgivningen. Vidare är det uppenbart att det finns flera faktorer som motverkar en större arbetskraftsinvandring, blant annat är språket ett problem. När det gäller behovet av ingenjörer tyder aktuella prognoser på att det alltjämt kommer att finnas ett stort underskott på kvalificerad arbetskraft inom vissa områden och branscher.

\section{Nordiske udfordringer i arbejdsindvandringspolitikken for kvalificeret arbejdskraft}

De nordiske arbejdsmarkeder har haft særlig let adgang til at rekruttere kvalificeret arbejdskraft indenfor EU/EØS området efter udvidelsen i 2004. Alligevel har alle de nordiske lande foretaget ændringer i reglerne for ophold- og arbejdstilladelse, og dermed lettet adgangen til de nordiske arbejdsmarkeder for tredjelandsborgere med særlige kvalifikationer. De forventede demografiske ændringer og den deraf følgende mangel på arbejdskraft er en af hovedforklaringerne bag denne udvikling. Paradoksalt nok er dette sket lige op til finanskrisens udbrud og den efterfølgende stigende ledighed.

Reglerne for opholds- og arbejdstilladelse er indrettet forskelligt i de enkelte nordiske lande på baggrund af forskellige strategiske overvejelser og forskellige reguleringstraditioner. Dog bygger reguleringen på tværs af de nordiske grænser på de samme grundlæggende principper. Lovgivnin- 
gen på området i de forskellige lande balancerer således alle mellem 1) at facilitere arbejdsgivernes efterspørgsel efter arbejdskraft og 2) at beskytte det nationale og europæiske arbejdsmarked mod dumping af løn og arbejdsvilkår.

De valgte strategier i forhold til at implementere reguleringen vedrørende højtuddannede fra tredjelande afhænger af en række forhold, hvor bl.a. den nationale erhvervsstruktur kan have betydning. Antallet af kvalificerede personer, der er kommet til de nordiske lande fra tredjelande realiteterne - er stadig forholdsvis beskedne, men tallene er stigende. De, som er kommet, er primært kommet fra Asien og her særligt Kina og Indien.

Den komparative analyse kan ikke entydigt pege på, om bestemte politikker eller reguleringer i de enkelte nordiske lande har resulteret $i$, at flere eller færre personer med særlige kvalifikationer er ankommet fra tredjelande. For det første er tidshorisonten for nogle af de lempelser, som er foretaget, meget kort, og man har endnu ikke set gennemslagskraften af tiltagene. For det andet er der store forskelle i vurderingen af, hvad der kendetegner kvalificeret arbejdskraft, og hvordan adgangsreglerne er indrettet, og som følge heraf er registreringen forskellig og til tider mangelfuld. Dette gør det svært at sammenligne data for tilgangen af udenlandsk arbejdskraft de nordiske lande imellem. 


\title{
1. Innledning
}

\author{
Line Eldring
}

I alle de nordiske landene, så vel som i Europa for øvrig, foregår det løpende debatter og analyser knyttet til de demografiske utfordringene framover. Befolkningsveksten er for lav til å veie opp for en alderspyramide som blir stadig mer topptung. Stadig færre yngre skal forsørge stadig flere eldre. På tross av stigende arbeidsledighet på kort sikt, er det stor uro knyttet til mangelen på arbeidskraft på lang sikt. Dette gjelder både jobber som krever lite utdanning, og det gjelder spesialister innenfor helseomsorg og tekniske profesjoner. I hele Norden er det en tendens til at stadig flere jobber for ufaglærte utføres av arbeidstakere med bakgrunn fra andre land. EU-utvidelsene mot øst i 2004 og 2007 viste seg å være startskuddet for en ny æra når det gjelder europeisk arbeidskraftsmobilitet. Langt flere arbeidstakere fra de nye EU-landene enn forventet benyttet seg av mulighetene til å reise og arbeide i Vest-Europa. Også til Norden har tilstrømningen fra naboland i Øst- og Sentral-Europa vært høy, og særlig til Norge. ${ }^{1}$

Nordiske virksomheter følger takten i internasjonaliseringen av næringslivet, og opererer oftere enn før tvers av de nasjonale arbeidsmarkedene. Både internasjonaliseringen og den demografiske utviklingen er potensielle drivere i utviklingen av regelverk så vel som av den faktiske arbeidskraftsmobiliteten. I nyere tid har de nordiske landene hatt strenge reguleringer når det gjelder arbeidsinnvandring fra land utenfor EU/EØSområdet. Samtidig har alle landene i Norden bestemmelser i sine regelverk som gjør det lettere å innvandre for særlig kvalifisert arbeidskraft, som for eksempel ingeniører. Erfaringen har likevel vært at det er krevende og vanskelig å rekruttere høykompetent arbeidskraft til virksomheter i Norden. Årsakene til dette er mange, og kan finnes i både avsenderog mottakerlandene, og ikke minst - i reguleringene for mobilitet av arbeidskraft mellom landene. Behovet for høyt utdannet arbeidskraft i de nordiske landene har imidlertid utløst en rekke tiltak og endringer i reguleringsregimene. I dette prosjektet har vi studert nærmere hva disse endringene har gått ut på, og hvordan de har virket. Den store likheten mellom de nordiske landene når det gjelder velferdsstatens innretning, arbeidsmarkedenes virkemåter og leve- og arbeidsvilkår mer generelt, gir et

\footnotetext{
${ }^{1}$ Dølvik, J.E. and L. Eldring (2008), Arbeidsmobilitet fra de nye EU-landene til Norden utviklingstrekk og konsekvenser. TemaNord 2008:502. København: Nordisk Ministerråd
} 
godt grunnlag for å studere både likheter og ulikheter i arbeidsinnvandringspolitikken og i resultatene av den.

I en situasjon med internasjonal konkurranse må de nasjonale reguleringene ses i sammenheng. Dette gjør det viktig å ha kunnskap om de nasjonale reguleringsregimene, interessene og det politiske handlingsrommet i hvert enkelt land. ${ }^{2}$ Arbeidsvandring og rekruttering av kompetanse over landegrenser skaper noen særskilte utfordringer. I et arbeidsmarked som i økende grad globaliseres vil konkurransen om kompetanse være stor, og både de politiske, sosiale og menneskelige kostnadene forbundet med arbeidsvandring vil bli synlige. Jakten på kompetansen kan imidlertid også ha sine skyggesider. Den kan lett føre til at migranter blir verdsatt ulikt, og at de får rettigheter ut fra hvilke kvalifikasjoner de har. Dette kan tappe noen land og områder for viktig kompetanse. Reguleringsmyndighetene vil dermed måtte se arbeidsvandring mellom land $\mathrm{i}$ et samfunnsmessig perspektiv som strekker seg ut over de nasjonale interessene.

Målsettingen for prosjektet har vært å studere og sammenlikne reguleringer, strategier og resultater i de nordiske landene når det gjelder arbeidsvandring av høykompetansegrupper fra tredjeland. Vi har kartlagt de politiske målsettingene og strategiene, og også initiativer tatt av arbeidsmarkedets parter med henblikk på å regulere og håndtere denne arbeidsinnvandringen. Analysen av reguleringsregimene omfatter kvalifisert $^{3}$ tredjelandsinnvandring generelt, mens undersøkelsen for øvrig har konsentrert seg om rekruttering og innvandring av ingeniørarbeidskraft. Dette valget ble gjort ut fra en antakelse om at etterspørselen etter ingeniører har vært stor i alle de nordiske landene, og at mangelen på teknologiarbeidskraft har vært en viktig driver i den pågående utviklingen av arbeidsinnvandringspolitikken.

Rapporten tar særlig for seg følgende temaer og problemstillinger:

Nasjonale lovreguleringer av arbeidsinnvandring fra tredjeland:

- Hvilke reguleringer gjelder for arbeidsinnvandring fra tredjeland når det gjelder høykvalifisert arbeidskraft?

- Hvilke sentrale endringer i det nasjonale regelverket for arbeidsinnvandring fra tredjeland har skjedd i de nordiske landene i løpet av de siste 10 årene? Og hva har vært begrunnelsen for eventuelle endringer?

\footnotetext{
${ }^{2}$ Menz, G. (2009), The Political Economy of Managed Migration. Oxford University Press.

${ }^{3}$ Som det framgår av landkapitlene, ligger det forskjellige definisjoner til grunn i de ulike landene når det gjelder hva som regnes som «kvalifisert/høykvalifisert» arbeidskraft. En fellesnevner er at vi her fortrinnsvis har studert regelverket som gjelder for innvandrende ingeniører.
} 
Rekruttering og innvandring av ingeniører fra tredjeland:

- Hva kjennetegner innvandringen fra tredjeland, og hvor mange ingeniører fra disse landene har fått arbeidstillatelse i de nordiske landene de siste 5-10 årene?

- Har det blitt iverksatt spesielle rekrutteringsinitiativ i forhold til ingeniører fra myndighetene eller andre sentrale aktører?

Nordiske utfordringer i arbeidsinnvandringspolitikken:

- Hva er de viktigste likhetene og ulikhetene mellom de nordiske landene i forhold til regulering av arbeidsinnvandring fra tredjeland?

- Hvilke faktorer hemmer/fremmer rekrutteringen av ingeniører fra tredjeland til Norden?

I analysene har vi vært opptatt av å ikke bare se på reglene, men også strategiene som ligger bak - og ikke minst hva som er realitetene når det gjelder faktiske resultater og virkninger. Problemstillingene er undersøkt gjennom bruk av foreliggende dokumentasjon, skriftlige kilder, statistikk fra relevante myndighetsorganer, samt informantintervjuer med representanter fra myndighetene og partene. Arbeidstaker- og arbeidsgiverorganisasjonene som er deltakere i prosjektet har omfattende kunnskap om ingeniørarbeidsmarkedet i de ulike landene, og har vært viktige informasjonskilder. Som det framgår av de ulike landkapitlene er det visse variasjoner når det gjelder hva slags data som har vært tilgjengelig, særlig når det gjelder statistikk.

Resultatene fra undersøkelsen presenteres i det følgende gjennom et kapittel for hvert av de nordiske landene; Danmark, Finland, Island, Norge og Sverige, og med et sammenfattende sluttkapittel. 



\section{Danmark}

Nana Wesley Hansen og Anne Marie Boesen

\section{Forkortelser}

- AC: Akademikernes centralorganisation (faglig hovedorganisation for akademikere)

- $A E$ : Arbejderbevægelsens Erhvervsråd

- BAT-kartellet: Bygge- Anlægs og Trækartellet

- CIRIUS: statslig styrelse der arbejder med internationalisering af uddannelser og læring, (ligger under Ministeriet for Videnskab, Teknologi og Udvikling)

- DA: Dansk Arbejdsgiverforening (Hovedorganisation for arbejdsgiverne)

- DI: Tidligere Dansk Industri (arbejdsgiverforening)

- DJØF: Danmarks Jurist- og Økonom forbund

- EURES: European Employment Services

- EU10: De nye EU medlemslande optaget i EU efter Østudvidelsen

- FTF: Hovedorganisation for offentligt og privatansatte

- HK: Handels- og Kontorfunktionærernes forbund

- IAK: Ingeniørernes Arbejdsløshedskasse

- IDA: Ingeniørforeningen i Danmark

- KL: Kommunernes Landsforening (interesse og medlemsorganisation for 98 kommuner i Danmark)

- LO: Landsorganisationen i Danmark (hovedorganisation for 18 fagforbund)

- PROSA: Forbundet af IT- professionelle

\subsection{National lovregulering af arbejdsindvandring fra tredjelande}

\subsubsection{Dagens regelværk for arbejdsindvandring fra tredjelande}

For at bo og arbejde i Danmark skal en tredjelands-statsborger have tildelt arbejds- og opholdstilladelse. Med fokus på at tiltrække kvalificeret arbejdskraft til Danmark har man siden 2001 indført fire ordninger: Positivlisten, Beløbsordningen, Koncernordningen og Greencard, ${ }^{4}$ der giver

\footnotetext{
${ }^{4}$ Udlændingeloven § 9.a stk.2
} 
nemmere adgang til Danmark for tredjelandsborgere med særlige kvalifikationer eller et jobtilbud med et vist lønniveau.

Positivlisten udgør en række beskæftigelsesområder, hvor der er mangel på arbejdskraft. Kan den udenlandske arbejdstager dokumentere et jobtilbud indenfor et af områderne på listen, er vedkommende berettiget til arbejds- og opholdstilladelse.

Hvis arbejdstageren kan dokumentere et jobtilbud med en årsindtægt på minimum 375.000 kr., kan vedkommende benytte sig af Beløbsordningen og dermed opnå arbejds- og opholdstilladelse uafhængigt af jobtypen.

Både for Positivlisten og for Beløbsordningen er det et krav for at få opholdstilladelse, at løn og ansættelsesvilkår er sædvanlige efter danske forhold.

Den tredje mulighed er Koncernordningen, der gør det muligt for en arbejdstager ansat i en virksomhed i udlandet at blive udstationeret i virksomhedens danske datter-, søster-, moderselskab eller lignende i en periode.

Endelig findes der Greencard-ordningen, som gør det muligt for kvalificerede udlændinge at få opholds- og arbejdstilladelse i Danmark i en periode på op til tre år. For at være berettiget til et Greencard skal arbejdstageren minimum opnå 100 point, der tildeles efter uddannelse, alder, erfaring, tilpasningsevne og sprogkundskaber. Greencard-ordningen adskiller sig fra de andre ordninger, idet den ikke er stadfæstet til et konkret job, men giver arbejdstageren mulighed for at opholde sig i landet for at søge job og arbejde. Det er Udlændingeservice, som udsteder Greencard på baggrund af ansøgerens dokumentation. Den statslige styrelse CIRIUS $^{5}$ medvirker i vurderingen af uddannelsesniveau, mens sprogniveau vurderes i forhold til de officielle danskprøver eller på baggrund af dokumentation om tidligere modtaget sprogundervisning. I forhold til ansøgerens tilpasningsevne tæller for eksempel tidligere uddannelsesophold i EU positivt.

Den udenlandske arbejdstager har mulighed for at medtage familie og hjemmeboende børn under 18 år på alle fire ovennævnte ordninger, dog kun under forudsætning af dokumenteret selvforsørgelse. Ordningerne er umiddelbart af tre års varighed, og derefter kan arbejdstageren søge om op til fire års forlængelse. Efter syv år kan vedkommende søge om permanent (tidsubegrænset) opholdstilladelse.

For at tiltrække udenlandske forskere har man indført en såkaldt forskerskat, der betyder, at såfremt vedkommende er rekrutteret i udlandet, kan personen vælge mellem at betale 25 \% i skat i op til tre år eller 33 \% i skat i op til fem år. Dette er en væsentlig reduktion eftersom det i ordningen er et krav, at forskeren har en løn på minimum 63.800 kr. pr. måned, hvilket der under normale forhold ville kvalificere vedkommende til at betale topskat på små 60 \%.

\footnotetext{
${ }^{5}$ CIRIUS er en statslig styrelse under Ministeriet for Videnskab, Teknologi og Udvikling, der arbejder med internationalisering af uddannelser og læringsmiljøer
} 
Der er endvidere udført en række tiltag, der tilgodeser udenlandske studerende. Myndighederne har forsøgt at skabe mere overskuelighed i regelværket for udenlandske studerende, og man har indført en jobsøgningsordning for udenlandske studerende, der afslutter en videregående uddannelse i Danmark. Efter endt uddannelse har den studerende mulighed for at opholde sig i landet op til seks måneder som jobsøgende. Såfremt den studerende finder et job, skal der ansøges om opholds- og arbejdstilladelse. Endelig findes en række særordninger for trainees, professionelle sportsudøvere og enkelte andre mindre grupperinger såsom religiøse forkyndere.

Den gruppe af tredjelandsborgere, som ikke kvalificerer sig til at søge eller få tildelt opholds- og arbejdstilladelse via ovennævnte ordninger, kan tildeles opholds- og arbejdstilladelse, hvis scrlige beskceftigelsesmæssige eller erhvervsmæessige hensyn taler for $\operatorname{det}^{6}{ }^{6}$ Udlændingeservice, der behandler ansøgningerne, lægger her vægt på, om der i forvejen er kvalificeret tilgængelig arbejdskraft inden for Danmark eller EU, og om arbejdet er af en særlig karakter. Det betyder, at der normalt ikke gives opholds- og arbejdstilladelser til sædvanligt faglært og ufaglært arbejde. Det er derudover nødvendigt, at ansøgeren har en jobkontrakt eller et konkret jobtilbud, hvor løn- og ansættelsesvilkår er sædvanlige efter danske forhold. Endelig skal den udenlandske arbejdstager være selvforsørgende og kunne godtgøre, at han råder over midler til at kunne forsørge sig selv det første år i Danmark. Arbejdstageren har mulighed for at medbringe sin ægtefælle og hjemmeboende børn under 18, hvis familien samlet set kan dokumentere at være selvforsørgende. Som familiesammenført behøver man ikke arbejdstilladelse for at arbejde i Danmark. Opholdstilladelsen betinges endvidere af, at den pågældende under opholdet ikke modtager hjælp efter lov om aktiv socialpolitik.

Betegnelsen scerlige beskceftigelsesmæessige eller erhvervsmæssige hensyn er noget ukonkret, og det kan for ansøgere og andre interesserede være svært at bedømme, hvornår der reelt er tale om sådanne hensyn. Kravene er fleksible afhængigt af efterspørgslen på arbejdskraft, hvorfor man i årene 2004-2008 under højkonjunkturen kunne konstatere en stigning i antallet af tredjelandsborgere, der får opholds- og arbejdstilladelse ud fra særlige beskcftigelsesmæessige eller erhvervsmæssige hensyn. Således er der ifølge tal fra Udlændingeservice i 2008 næsten tre gange så mange tredjelandsborgere, der har opholdstilladelser på baggrund af denne hjemmel, sammenlignet med tallet i 2004.

\subsubsection{Udviklingen i regelvcerket og rekrutteringsinitiativer for højtkvalificeret arbejdskraft}

De første tiltag for rekruttering af særlig kvalificeret udenlandsk arbejdskraft blev taget i januar 2001, hvor man vurderede, at der var akut mangel

${ }^{6}$ Udlændingeloven § 9.a stk.2 
på it-specialister, hvorfor der blev indført en fast track ordning for denne type arbejdskraft. Ordningen blev i juni 2002 videreført i Jobkortordningen og den dertilhørende Positivliste, hvor man i udgangspunktet kun opstillede syv beskæftigelsesområder, hvor man vurderede, at der var mangel på arbejdskraft. It-specialister blev således en del af Positivlisten, ligesom ingeniører fra start af optrådte herpå. I foråret 2007 blev den oprindelige Jobkortordning revideret, og Positivlisten blev udvidet til 20 områder, herunder bl.a. maskinmestre, landinspektører og bygningskonstruktører. Ved samme revision indførte man Beløbsordningen, der i starten havde et indtjeningskrav på minimum 450.000 kr. årligt. Beløbsordningen adskiller sig fra de andre ordninger ved ikke at være tilknyttet en bestemt type stillinger. Således behøver ansøgeren ikke medsende eksamensbevis, så længe personen har en jobkontrakt, der sikrer en årsløn over beløbsgrænsen. Senere i oktober samme år trådte Greencard-ordningen i kraft, som i første omgang gjorde det muligt for højtkvalificerede udlændinge at komme til Danmark for at søge job i seks måneder. I sin oprindelige form var den danske Greencard-ordning således alene en jobsøgningsordning. Ordningen havde bred opbakning fra regeringen og enkelte af oppositionspartierne, mens det ellers regeringsstøttende parti Dansk Folkeparti som udgangspunkt var modstander af ordningen, som anså den for at være en unødvendig åbning af dansk udlændingelovgivning.

Allerede i februar 2008 blev initiativerne på området igen revurderet, og regeringspartierne (Venstre og Konservative), Dansk Folkeparti, Det Radikale Venstre og Ny Alliance indgik en aftale om en Jobplan, der blandt andet skulle forbedre mulighederne for højtkvalificeret udenlandsk arbejdskraft. ${ }^{7}$ Positivlisten blev endnu en gang udvidet til også at omfatte bachelorer og bestemte mellemlange videregående uddannelser, og beløbsgrænsen blev sænket til 375.000 kr. I den første ordning fra 2007 skal Greencard-indehaveren efterfølgende søge om formel opholds- og arbejdstilladelse, men i Jobplanen blev det besluttet, at arbejdstageren, der opnår et Greencard samtidig får en formel opholds- og arbejdstilladelse fra dag ét, også selvom vedkommende ikke har noget arbejde. Perioden blev endvidere udvidet fra seks måneder til de nuværende tre år ${ }^{8}$. Endeligt var det også ved aftalen om Jobplanen, at Koncernordningen blev indført.

Myndighederne har ikke på noget tidspunkt opstillet klart definerede måltal for ordningerne. I stedet er succeskriteriet, at udviklingen følges tæt, med henblik på løbende at kunne foretage nødvendige ændringer. Det overordnede mål for myndighederne er ikke at få flest mulige udenlandske arbejdstagere til Danmark, men at få det antal ind, som passer til behovet på arbejdsmarkedet på det givne tidspunkt. Ifølge aftalen om Jobplanen skal ændringer i konjunkturer og ledighed således have direkte

\footnotetext{
${ }^{7}$ Aftale om en jobplan, februar 2008

${ }^{8}$ En udvidelse som ikke gælder jobsøgningsordningen for studerende, hvor opholdsperioden fortsat er seks måneder.
} 
betydning for, hvorvidt der åbnes op for yderligere arbejdskraft fra udlandet. Fx. revideres stillingsbetegnelserne på Positivlisten to gange årligt på baggrund af „Arbejdsmarkedsbalancemodellen“. Arbejdsmarkedsbalancen udformes af de danske beskæftigelsesregioner og skal give overblik over muligheder for at få job inden for omkring 1.100 stillingsbetegnelser. I datagrundlaget for balancen indgår 1) oplysninger vedrørende ledighed, 2) oplysninger vedrørende beskæftigelse og jobåbninger - begge dataområder, som hentes fra Danmarks Statistik, og som er baseret på registerdata og større stikprøveundersøgelser og 3) data fra den landsdækkende virksomhedssurvey, som Arbejdsmarkedsstyrelsen gennemfører hvert halve år. Surveyen foretages som en stikprøve blandt ca. 20.000 virksomheder og undersøger virksomheders rekrutteringsbehov. I tillæg til at indgå som grundlag for revidering af Positivlisten benyttes Arbejdsmarkedsbalancen også af de lokale jobcentre og arbejdsløshedskasser til at vejlede og rådgive ledige om beskæftigelsesmuligheder. ${ }^{9}$

Mens Positivlisten udformes administrativt, bliver Beløbsordningen og pointsystemet til Greencard-ordningen justeret afhængigt af politiske forhandlinger og trepartsdrøftelser. Der er i den forbindelse nedsat et trepartsudvalg, der består af integrationsministeren, beskæftigelsesministeren og hovedorganisationerne for arbejdstager og arbejdsgiver. Trepartsudvalget mødes minimum to gange årligt som led i den generelle og løbende overvågning af rekrutteringsindsatsen af udenlandsk arbejdskraft ${ }^{10}$. Med udgangspunkt i udviklingen i nøgletallene, som udarbejdes af Arbejdsmarkedsstyrelsen drøfter parterne ubalancer på arbejdsmarkedet, brugen af adgangsregler og kommer generelt med input til regeringen. Nøgletalssystemet ${ }^{11}$ startede med tilgangstal for arbejdstagere fra de nye EU-lande, men blev i 2008 udvidet med tilgangstal for tredjelandsborgere. Det er via nøgletallene muligt at danne sig et overblik over tilgangen af tredjelandsborgere og deres fordeling på køn, alder, opholdsgrundlag og nationalitet. I 2010 er systemet yderligere blevet udvidet med bestandstal, som kan fordeles på opholdsgrundlag, længde af ophold, branche, nationalitet og geografisk område.

Derudover findes også en anden gruppe: „Følgegruppen til drøftelser med arbejdsmarkedsparter“. Denne var allerede nedsat inden aftalen om Jobplanen og består af en bredere kreds af arbejdsmarkedets parter og repræsentanter fra relevante myndigheder. Ifølge Jobplanen skal gruppen fremover fokusere på arbejdstagere fra såvel de nye EU-lande (EU10) som fra tredjelande. Fokus er forsat på at forebygge omgåelse af regler og illegalt arbejde samt oplysning om gældende regler og rettigheder på det danske arbejdsmarked.

Som følge af Jobplanen fra 2008 blev der ud over revisionen i regelværket også taget initiativ til at forbedre den aktive rekruttering af uden-

\footnotetext{
${ }^{9}$ Arbejdsmarkedsstyrelsen, Notat af 9. nov. 2007

${ }^{10}$ Frem til midten af 2009 har trepartsudvalget kun mødtes én gang siden udvalgets nedsættelse.

${ }^{11}$ Offentliggøres på [www.jobindsats.dk]
} 
landsk arbejdskraft og matche virksomheder og højtkvalificeret arbejdskraft. Blandt andet er der blevet etableret tre Work in Denmark-centre i Syd-, Øst- og Vestdanmark, som har til opgave at hjælpe danske virksomheder og udenlandske jobsøgere med at finde hinanden. Centrenes arbejde indbefatter således både formidling af arbejdstagere fra EU (via EURES) og arbejdstagere fra tredjelande, der søger job i Danmark. I forlængelse af oprettelsen af centrene har Arbejdsmarkedsstyrelsen udviklet hjemmesiden [Workindenmark.dk], der fungerer som Danmarks officielle hjemmeside for rekruttering og jobsøgning af alle typer udenlandsk arbejdskraft. Hjemmesiden indeholder information om rekruttering til arbejdsgivere, information om arbejds- og levevilkår i Danmark til udenlandske arbejdstagere samt en CV-database. I CV-databasen kan udenlandske jobsøgere fremlægge deres $\mathrm{CV}$ og arbejdsgivere kan oprette jobannoncer og søge efter udenlandsk arbejdskraft. CV-basen er målrettet alle typer arbejdskraft med varierende uddannelsesbaggrund og kvalifikationer. Centrene oplever en høj koncentration af brugere i CV-basen fra lande som Indien og Pakistan, som ikke nødvendigvis er højt kvalificerede. Flere danske virksomheder har derfor frabedt sig at have deres engelske jobannoncer på hjemmesiden, da langt de fleste ansøgninger kom fra ikke-kvalificerede arbejdstagere.

Work in Denmark-centrene har yderligere en lang række serviceopgaver såsom; at bistå med at gennemføre større internationale rekrutteringsinitiativer, at være specialistfunktion i forhold til de lokale jobcentres rekruttering af udenlandsk arbejdskraft, at opretholde en hotline for polske arbejdstagere og fra 1. januar 2009 tilbydes yderligere professionel hjælp til rekrutteringsprocessen mod betaling til virksomheder.

I tillæg til de tre Work in Denmark-centre i Danmark oprettede man også et Work in Denmark-center i New Delhi, Indien. Centret giver information om Danmark for arbejdssøgende indere og bred rådgivning til danske arbejdsgivere, som ønsker at søge arbejdskraft i Indien. Centret åbnede i oktober 2008, men Udenrigsministeriet indstillede markedsføringsaktiviteterne allerede i februar 2009. Efter centrets åbning har efterspørgslen fra de danske virksomheder været næsten ikke-eksisterende som følge af den finansielle krise, hvorfor tiden nu bruges på at geare centret til, når efterspørgslen stiger igen. Det har vist sig nødvendigt, at udarbejde nogle forholdsregler og kontrolmekanismer, da fx. dokumentfalskning af eksamenspapirer har vist sig at være et større problem end forudset, da centret åbnede. Centret er et pilotprojekt og evalueres i efteråret 2009. Frem til midten af 2009 har man oplevet et stort arbejdsudbud fra Indien med mange henvendelser til centret. Særligt Greencardordningen har været i fokus, hvor det er muligt at søge til Danmark uden en konkret jobkontrakt. Centret vurderer, at omkring $95 \%$ af alle henvendelser omhandler Greencard, hvoraf en stor del kommer fra personer uden særlige kvalifikationer. Omvendt er det begrænset med henvendelser angående Beløbsordningen og Positivlisten. Centrets opfattelse er, at 
når disse ordninger benyttes har virksomhederne ofte klaret rekrutteringsprocessen selv og etableret kontakt med de ønskede arbejdstagere. Dette gælder særligt inden for områderne læger, ingeniører og itspecialister, hvor virksomheder på nuværende tidspunkt internt klarer rekrutteringerne.

Som opfølgning på Jobplanen fra 2008 blev der endvidere nedsat en tværministeriel Task Force, med deltagelse fra otte ministerier: Skatteministeriet, Beskæftigelsesministeriet, Ministeriet for Sundhed og Forebyggelse, Økonomi- og Erhvervsministeriet, Ministeriet for Flygtninge, Indvandrer og Integration, Indenrigs- og Socialministeriet, Finansministeriet og Udenrigsministeriet. Task Forcen har haft til opgave at identificere de forskellige barrierer, der besværliggør rekruttering af udenlandsk arbejdskraft, og herefter komme med løsningsforslag til forenkling. Fokus har ikke været på de udlændingeretlige og opholdsretlige regler, men i stedet på forenklingsmuligheder og afbureaukratisering af de administrative processer indenfor og imellem myndigheder. Sideløbende har Task Forcen bedt analysefirmaet Deloitte om at udarbejde et barrierekatalog, der både kortlægger regler, myndighedsroller og administrative processer for international rekruttering, og som opsamler erfaringer fra arbejdsgivere og udenlandske arbejdstagere om barrierer for rekrutteringen. ${ }^{12}$ Barrierekataloget blev afleveret i november 2008 til behandling hos regeringen, mens Task Forcens arbejde fortsatte ind i 2009. Det er endnu usikkert, hvilke konkrete initiativer arbejdet munder ud i. Den nuværende lavkonjunktur i kølvandet på finanskrisen har hævet andre emner op på den politiske dagsorden, og tiden vurderes af mange politikere ikke at være inde til at tage nye initiativer på området. Dette afspejlede sig også i en hurtig affærdigelse af de forslag Arbejdsmarkedskommissionen kom med i deres rapport fra august 2009 i forhold til rekruttering af udenlandsk arbejdskraft.

Endnu et tiltag i forbindelse med Jobplanen er udviklingen af Familiepakker, der er en informationspakke til den udenlandske arbejdstager og dennes familie med det formål at sikre bedre viden om Danmark og bedre integration i det danske samfund. Informationsmaterialet forventes færdig i løbet af efteråret 2009. Der er endvidere tilknyttet mindre puljer til initiativet om familiepakker til at gennemføre forskellige forsøgsordninger lokalt, der blandt andet kan introducere familien til lokalsamfundet, foreningslivet og give information om dagpasnings- og skoletilbud. Endelig arbejder man på at udvikle internetbaseret danskundervisning, som den udenlandske arbejdstager kan starte på allerede inden ankomst til Danmark.

Opsummerende kan man pege på tre karakteristika, der kendetegner udviklingen i det danske regelværk og rekrutteringsinitiativer for højtkva-

\footnotetext{
${ }^{12}$ Deloitte har gennemført en række interviews og workshops med myndigheder, organisationer, arbejdsgivere og udenlandske arbejdstagere. Der er gennemført telefoninterview med 337 virksomheder og 112 arbejdstagere. Barrierekataloget indeholder forslag til forbedring af eksisterende serviceydelser fra myndigheder, udvikling af nye serviceydelser, forbedring af processer mellem myndigheder og processer internt i den enekelte myndighed.
} 
lificeret arbejdskraft fra tredjelande siden 2001: For det første har den danske lovgivning fra starten af været målrettet mod at lette adgangen for helt specifikke faglige profiler fra tredjelande, som man vurderer, at virksomhederne efterspørger. Dette har ændret sig noget ved indførslen af Beløbsordningen og Greencard-ordningen i 2007, regelsættet er dog stadig relativt selektivt. For det andet er der sket en udvikling fra en passiv mod en mere aktiv rekrutteringsstrategi. Fra at fokusere på at lette adgangen ved særordninger for højtkvalificeret arbejdskraft er der kommet fokus på „branding“ af Danmark i udlandet, og der er taget initiativer til egentlig rekruttering og „matching“ af arbejdsgivere og arbejdstagere. For det tredje er rekrutteringsstrategien blevet udvidet fra et fokus på tiltrækning af arbejdskraft til også at rumme initiativer til fastholdelse af arbejdskraften.

\subsubsection{EU's rolle i regulering af arbejdsindvandring fra tredjelande}

Danmark deltager ikke i EU’s Blue Card-ordning vedtaget i maj 2009 på grund af det danske EU-forbehold på det retlige område. Danmarks forbehold om EU-samarbejde om retlige og indre anliggender er blevet betegnet som et „forbehold med forbehold““. ${ }^{13}$ Det er således ikke alle dele Danmark står udenfor, men udelukkende det overstatslige samarbejde, som også Blue Card-ordningen er en del af.

Arbejdsgiverorganisationerne og fagforeninger såsom den danske ingeniørforening er som udgangspunkt positive over for rekrutteringsinitiativer på EU-niveau. Den generelle argumentation er, at den globalt orienterede arbejdskraft stiller en række krav, og hvis Danmark kun har et meget snævert udbud af interessante job, vil de ikke nødvendigvis søge hertil. Derfor er det mere givtigt, hvis man åbner det europæiske arbejdsmarked så arbejdstageren har mulighed for at flytte fra land til land, og hermed vil Danmark kunne hægte sig på et fælles europæisk brand. Blue Card-ordningen betyder også, at EU signalerer, at regionen mangler arbejdskraft. Arbejdsgiversiden rapporterer at have oplevet at indere og kinesere har indtrykket af „Fort Europa“ som en lukket klub. DI oplevede det derfor som positivt, at inderne i oktober 2008, ved åbningen af Work in Denmark-centret i Delhi, havde hørt om, at Blue Card-ordningen var på vej, og at Europa ville begynde at åbne sine grænser for, at udenlandske specialister kan komme dertil for at arbejde. Når det er sagt, finder både arbejdstager- og arbejdsgiversiden imidlertid også enkelte elementer i ordningen bekymrende. I ordningens bestemmelser om at skabe et efterspørgselsdrevet adgangssystem tages der blandt andet udgangspunkt i etableringen af en form for fælles mindsteløn som adgangskrav. Adgangskravet om mindsteløn skal sikre en minimal harmonisering af lønniveau mellem EU-landene og forebygge løndumping i enkelte lande. ${ }^{14}$

\footnotetext{
${ }^{13}$ Dansk Institut for Internationale Studier 2008

${ }^{14}$ Council Directive 2009/50/EC of 25 May 2009
} 
En ordning, som harmonerer dårligt med det danske system, hvor løn aftales mellem arbejdsmarkedets parter via overenskomster.

På lønmodtagersiden ser LO også perspektiver i et europæisk samarbejde. Særligt mener de dog, at der bør fokuseres på bedre sikring af udenlandske lønmodtageres løn- og arbejdsvilkår, og at disse er på lige vilkår med det, som gælder nationalt.

Samlet set har EU-initiativerne på området for at tiltrække højtkvalificeret arbejdskraft fra tredjelande hidtil været relativt sparsomme, og det har således ikke voldt Danmark større problemer at stå udenfor de få konkrete initiativer, som er taget.

I forhold til den konkrete rekrutteringspraksis har den koordinerede formidling af udenlandsk arbejdskraft frem til og med 1. oktober 2008 primært foregået via det europæiske EURES samarbejde. I Danmark har EURES frem til kommunalreformen i 2007 ligget forankret i de fjorten arbejdsformidlingsregioner (AF-regioner) med én til to medardejdere $\mathrm{i}$ hver AF-region. Efter kommunalreformen ændredes EURES konstruktionen, således at én EURES kontaktperson fremover blev placeret $i$ hvert af de 91 nye kommunale jobcentre, som afløste AF systemet. Samtidig oprettede man én EURES Specialfunktion, hvor der sad syv EURESvejledere, som havde til opgave sammen med EURES-manageren i Arbejdsmarkedsstyrelsen at støtte jobcentrenes opgaveløsning, sikre faglig udvikling, deltagelse i det europæiske samarbejde og udvikle rekrutteringsprojekter. Som følge af regeringens Jobplan i 2008 ændredes konstruktionen atter en gang med henblik på at styrke rekrutteringen af udenlandsk arbejdskraft. Herefter etablerede man de tre Work in Denmarkcentre med i alt 32 medarbejdere, som fremover har overtaget rekruttering af udenlandsk arbejdskraft både indenfor og udenfor EU. Flertallet af de ansatte i Work in Denmark-centrene er EURES-vejledere, og man har fastholdt ordningen med EURES kontaktpersoner i hvert kommunalt jobcenter.

\subsubsection{Parterne på arbejdsmarkedet og rekrutteringsstrategier}

I Danmark er der stærk tradition for trepartsforhandlinger og generel inddragelse og høring af arbejdsmarkedets parter ved beskæftigelses- og arbejdsmarkedsrelaterede spørgsmål. Dette er også tilfældet ved rekruttering af udenlandsk arbejdskraft. De centrale parter på både det private og det offentlige arbejdsmarked har deltaget i de såkaldte trepartsforhandlinger, og ved særlige lejligheder er interesseorganisationer som BATkartellet blevet inviteret til at deltage i høringerne. Også i forbindelse med administrationen af ordningerne findes et vist samarbejde mellem myndigheder og de berørte faglige organisationer. Det er Udlændingeservice, der administrerer de forskellige job-ordninger, men i de tilfælde, hvor de er i tvivl om, hvorvidt ansættelsesvilkårene svarer til de danske forhold, høres de forhandlingsberettigede faglige organisationer på områ- 
det. Dette er praksis inden for fagområderne ingeniører, læger, sygeplejersker og it-specialister.

Derudover har enkelte af de berørte organisationer også taget en række selvstændige politiske og praktiske initiativer for at tiltrække kvalificeret udenlandsk arbejdskraft og få denne til at blive i landet. Der er dog store forskelle i deltagelse og aktivitetsniveau blandt de forskellige organisationer, som repræsenterer arbejdsgivere og fagforeninger med særlig interesse i rekruttering af højtkvalificeret arbejdskraft.

Dansk Arbejdsgiverforening (DA) er hovedforbundet på arbejdsgiversiden og er en aktiv politisk spiller, når det kommer til udenlandsk arbejdskraft. To af deres markante medlemsorganisationer DI (repræsenterer danske industri og handel og serviceområderne og er den største medlemsorganisation i DA) og Dansk Erhverv (repræsenterer handel, videnbaseret rådgivning, oplevelse, transport og service) har derudover stort fokus på området og har været særligt aktive i at fremme rekrutteringsinitiativer. Både DI og Dansk Erhverv har de sidste otte år haft strategisk fokus på at lette adgangen for udenlandsk arbejdskraft, og fra slutningen af 2006 har DI presset på for reformer med henblik på at smidiggøre regelværket for adgang til Danmark for højtkvalificeret arbejdskraft. Kritikken har særligt været på den daværende Jobkort-ordning, som de mente var for restriktiv. I 2007 fremlagde DI deres "Plan B” til øgning af den danske arbejdsstyrke, hvor en række forslag til forbedring af den internationale rekruttering også indgik. Begge organisationer mener imidlertid, at man er kommet langt med den nuværende Jobplan, der overordnet har lettet adgangen til det danske arbejdsmarked. Særligt sænkningen af beløbsgrænsen, vurderer arbejdsgiverne, har haft afgørende betydning. De mener endvidere begge, at det er vigtigt at ændre ordningerne yderligere, men den globale finansielle krise har vanskeliggjort politiske forhandlinger siden slutningen af 2008. Dansk Erhverv mener særligt, at det er hæmmende, at der for de fleste ordninger kræves en jobkontrakt, hvorfor de ønsker Greencard-ordningen udvidet. DI har endvidere presset på for at fremme den aktive rekruttering i udlandet. Fx. har DI påpeget at regeringens første udkast til skrivelsen „Handlingsplan for Offensiv Global Markedsføring“ fra 2007 hovedsageligt havde fokus på Danmark som turistland, mens der ifølge DI ikke var lagt nok vægt på Danmark som arbejdsland. ${ }^{15}$ DI har endelig i samarbejde med IDA presset på for, at den danske udenrigstjeneste blandt andet via ambassaderne mere offensivt skal arbejde på at brande Danmark som et arbejdsland.

Ud over at bearbejde myndighederne via høringssvar og politikudspil har DI og Dansk Erhverv også taget selvstændige initiativer. DI har understøttet en række private investorers projekt med hjemmesiden "Life in Denmark” [www.lifein.dk], der skal gøre det nemmere for udenlandske

\footnotetext{
${ }^{15}$ Det skal her bemærkes, at regeringen kort efter i oktober 2007 fremlagde en handlingsplan for international rekruttering „Danmark et godt sted at arbejde“, der blandt andet havde som målsætning at markedsføre Danmark som arbejdsland.
} 
arbejdstagere at søge information om livet i Danmark hjemmefra og oprette netværk ved ankomst til Danmark. Dansk Erhverv har været primus motor i et andet lignende projekt; „Expat in Denmark“ [www.expatindenmark. com], der har til formål at lave et netværk blandt udenlandske arbejdstagere og virksomheder, der kan bruges til at organisere faglige og sociale events samt fungere som et fælles forum. „Expat in Denmark“ er efterfølgende blevet sponsoreret af Økonomi- og Erhvervsministeriet, der har investeret omkring 4,5 millioner kr. i projektet. Projekterne er arbejdsgiverorganisationernes bidrag til at øge brandingen af Danmark og fastholde den arbejdskraft, der kommer til landet. Fælles for begge projekter er, at det er initiativer startet på virksomheds- eller organisationsniveau, hvor myndighederne efterfølgende har valgt at understøtte initiativerne økonomisk.

På lønmodtagersiden er der større forskelle i holdninger til den internationale rekruttering. Organisationer som Ingeniørforeningen i Danmark (IDA) og Akademikernes Centralorganisation (AC) betragter rekrutteringen af udenlandsk arbejdskraft til Danmark som et positivt fænomen, der primært styrker jobskabelsen på det danske arbejdsmarked. Hermed adskiller de akademiske organisationer sig noget fra de andre forbund på lønmodtagersiden som Landsorganisationen i Danmark (LO, der er hovedorganisation for de faglærte og ufaglærte fagforeninger) og FTF (der er hovedorganisation for professions- og erhvervsrettede uddannelser), der har understreget at efteruddannelse og opkvalificering af den eksisterende arbejdsstyrke er lige så vigtig som rekruttering af udenlandsk arbejdskraft. Sidstnævnte fremgår også af den aftale om rekruttering af arbejdskraft som LO og DA indgik i februar 2008. ${ }^{16}$ LO er åben overfor rekruttering af kvalificeret arbejdskraft med lang eller mellemlang uddannelse, men er noget kritisk i forhold til brugen af Arbejdsmarkedsbalancen som styringsredskab for, hvilken arbejdskraft der skal rekrutteres. LO mener at styringen primært bør foregå via trepartsdrøftelser med arbejdsmarkedets parter. LO, DA og KL (Kommunernes Landsforening) indgår også i et samarbejde omkring „Welcometo“-initiativet [www.welcometo.dk], som skal forbedre modtagelse og integration af udenlandsk arbejdskraft og forankre integrationsprocessen i kommunerne.

AC har ikke selvstændigt taget initiativer til rekruttering af udenlandsk arbejdskraft, men overladt opgaven til deres medlemsorganisationer. Deres primære indsats er påvirkning af politikformuleringsprocessen. Således sidder de med i følgegruppen til trepartsforhandlingerne, regeringens Task Force og lignende fora. AC har søgt at rette fokus mod tiltrækning af udenlandske studerende, som efter endt uddannelse kan opnå ansættelse i landet. I 2007 fremførte AC således et forslag, der indbefattede arbejdsstipendier til de dygtigste udenlandske studerende, så de kan få en gratis uddannelse i Danmark, mod at de efterfølgende arbejder mi-

\footnotetext{
${ }^{16}$ LO-DA aftale februar 2008
} 
nimum to år i landet. Et lignende forslag er i april 2009 blevet luftet af den tidligere danske videnskabsminister Helge Sander ${ }^{17}$.

IDA, som i dag står udenfor AC-organisationen, har de sidste 10 år særligt haft fokus på tiltrækning af højtkvalificeret udenlandsk arbejdskraft, og meget af deres aktivitet på området går ud på at påvirke myndighederne via høringssvar og politikudspil. Derudover har IDA konkret arbejdet sammen med Beskæftigelsesministeriet og Arbejdsmarkedsstyrelsen om forskellige initiativer og konferencer. Sammen med DI og Djøf tog IDA endvidere i 2006 initiativ til en ordning med jobambassadører, der blev finansieret af Arbejdsmarkedsstyrelsen. Ordningen gik ud på at benytte medlemmer fra organisationerne, der arbejder i udlandet til at informere om dansk arbejdsmarked og jobmuligheder i Danmark samt opbygge netværk. IDA har endvidere sammen med arbejdsgiverparten DI også været aktiv i processen med, at få myndighederne til at opfatte ambassadernes rolle som en rekrutteringsbase. Sidstnævnte indbefatter, at de danske ambassader aktivt skal medvirke til at brande arbejdskraft.

Et særligt problemområde, som både DI og IDA har påpeget i forbindelse med de nye særordninger for kvalificeret arbejdskraft, er at sagsbehandlingstiden for ansøgninger fra arbejdstagere fra tredjelande er alt for lang. IDA har således oplevet at sagsbehandlingstiden ofte har været på op til 3-4 måneder, allerede inden de modtager dem til høring, og de er derfor noget bekymrede for om selve sagsbehandlingen optræder som barriere for den kvalificerede udenlandske arbejdskraft. Servicemålet for Positivlisten, Beløbsgrænsen, Koncernordningen og Greencard er hos Udlændingeservice en sagsbehandlingstid på maksimalt én måned fra ansøgningen er indleveret til en dansk myndighed og såfremt sagen er fuldt oplyst. Det vil sige fra det tidspunkt, hvor alle de nødvendige oplysninger for at belyse sagen er modtaget. Fra perioden fra 1. maj-31. juli 2009 lever sagsbehandlingen op til servicemålet i $95 \%$ af sagerne under Positivlisten (89 afgjorte sager), 97 \% for Beløbsordningen (858 afgjorte sager) og $78 \%$ af sagerne under Greencard-ordningen (739 afgjorte sager). ${ }^{18}$ I langt hovedparten af Greencard-sagerne har det dog vist sig nødvendigt at indhente yderligere oplysninger, da der ikke har været indgivet tilstrækkelig information. Kun omkring $20 \%$ af disse sager indeholder fra start af alle oplysninger. ${ }^{19}$ Fra begyndelsen af 2009 og frem til midten af oktober 2009 er der indgivet flere end 4000 ansøgninger om opholdstilladelse via Greencard-ordningen. Dette er langt flere end forventet og har påvirket sagsbehandlingstiden negativt.

\footnotetext{
${ }^{17}$ Helge Sander nævner blandt andet forslaget i det indledende kapitel i debatbogen „Fremtidens universiteter“ fra forlaget Gyldendal, som blev lanceret i foråret 2009.

${ }^{18}$ Kilde: Udlændingeservice, bidrag af 19. okt. 2009

${ }^{19}$ Ibid.
} 
Oversigtsboks: Initiativer til rekruttering af kvalificeret arbejdskraft fra 3. lande

\begin{tabular}{|c|c|c|}
\hline Initiativ & Indhold & Organisation/Myndighed \\
\hline \multicolumn{3}{|l|}{ Fællesnordiske initiativer } \\
\hline CrossBorder-funktion (afviklet) & $\begin{array}{l}\text { Fælles markedsføring af } \\
\text { arbejdspladser i den skandina- } \\
\text { viske sundhedssektor målrettet } \\
\text { al udenlandsk arbejdskraft ikke } \\
\text { bare fra 3. lande }\end{array}$ & $\begin{array}{l}\text { EURES samarbejde i } \\
\varnothing \text { resundsregionen }\end{array}$ \\
\hline Toolbox på EU's EURES portal & $\begin{array}{l}\text { Information til arbejdstagere fra } \\
\text { 3. lande }\end{array}$ & $\begin{array}{l}\text { EURES samarbejde mellem de } \\
\text { skandinaviske og baltiske lande }\end{array}$ \\
\hline \multicolumn{3}{|c|}{ Myndighedsinitiativer til konkret rekruttering og fastholdelse } \\
\hline $\begin{array}{l}\text { Tre Work in Denmark Centre } \\
\text { oprettes og }\end{array}$ & $\begin{array}{l}\text { Information og formidling af } \\
\text { arbejdskraft }\end{array}$ & Beskæftigelsesministeriet \\
\hline $\begin{array}{l}\text { [www.workindenmark.dk] } \\
\text { etableres }\end{array}$ & $\begin{array}{l}\text { CV base til brug for jobsøgere } \\
\text { og virksomheder }\end{array}$ & Arbejdsmarkedsstyrelsen \\
\hline \multirow{3}{*}{$\begin{array}{l}\text { Work in Denmark-center i New } \\
\text { Delhi, Indien (Pilotprojekt) }\end{array}$} & \multirow{3}{*}{$\begin{array}{l}\text { Markedsføring af Danmark og } \\
\text { screening af ansøgere til job i } \\
\text { Danmark }\end{array}$} & Beskæftigelsesministeriet \\
\hline & & Arbejdsmarkedsstyrelsen \\
\hline & & Udenrigsministeriet \\
\hline Tværministeriel & \multirow{4}{*}{$\begin{array}{l}\text { Identificering af barrierer, } \\
\text { forenkling af kontrolforanstalt- } \\
\text { ninger og afbureaukratisering } \\
\text { af de administrative processer } \\
\text { internt i det offentlige system }\end{array}$} & \multirow{4}{*}{$\begin{array}{l}\text { Skatteministeriet, Beskæftigel- } \\
\text { sesministeriet, Ministeriet for } \\
\text { Sundhed og Forebyggelse, } \\
\text { Økonomi- og Erhvervsministe- } \\
\text { riet, Ministeriet for Flygtninge, } \\
\text { Indvandrer og Integration, } \\
\text { Indenrigs- og Socialministeriet, } \\
\text { Finansministeriet og } \\
\text { Udenrigsministeriet }\end{array}$} \\
\hline Task Force & & \\
\hline Barrierekatalog & & \\
\hline $\begin{array}{l}\text { (Arbejdet færdiggjort, men } \\
\text { resultater er endnu ikke fær- } \\
\text { digbehandlet) }\end{array}$ & & \\
\hline Familiepakker & $\begin{array}{l}\text { Informationspakke og puljer til } \\
\text { lokale forsøgsordninger til } \\
\text { bedre integration af arbejdsta- } \\
\text { ger og dennes familie. For- } \\
\text { søgsordningerne resulterer i en } \\
\text { lang række mindre initiativer } \\
\text { hvor både offentlige og private } \\
\text { aktører er involverede. }\end{array}$ & $\begin{array}{l}\text { Ministeriet for Flygtninge, } \\
\text { Indvandrer og Integration }\end{array}$ \\
\hline \multicolumn{3}{|c|}{ Organisations-, virksomheds- og myndighedssamarbejde } \\
\hline [www.expatindenmark.dk] & $\begin{array}{l}\text { Fagligt og socialt netværk for } \\
\text { midlertidig udenlandsk ar- } \\
\text { bejdskraft i Danmark }\end{array}$ & $\begin{array}{l}\text { Økonomi- og Erhvervs- } \\
\text { ministeriet, Dansk Erhverv, } \\
\text { Finansrådet og ugeavisen The } \\
\text { Copenhagen Post }\end{array}$ \\
\hline [www.welcometo.dk] & $\begin{array}{l}\text { Skal forankre modtagelse, } \\
\text { fastholdelse og integration af } \\
\text { udenlandsk arbejdskraft lokalt i } \\
\text { kommunerne }\end{array}$ & LO, DA, KL \\
\hline $\begin{array}{l}\text { Netværk for virksomheder med } \\
\text { udenlandske medarbejdere }\end{array}$ & $\begin{array}{l}\text { Netværk med fokus på rekrut- } \\
\text { tering, ansættelse og fasthol- } \\
\text { delse af udenlandske medar- } \\
\text { bejdere. I } 2009 \text { tæller netvær- } \\
\text { ket } 100 \text { virksomheder. }\end{array}$ & DI \\
\hline
\end{tabular}




\subsection{Rekruttering og invandring af ingeniører i tal}

\subsubsection{Mobilitet i tal}

Til trods for de mange rekrutteringsinitiativer er antallet af kvalificerede arbejdstagere fra tredjelande begrænset i Danmark. Diagram 1 viser det samlede antal af arbejdstagere, der fik opholds- og arbejdstilladelser via henholdsvis Jobkortordningen og efterfølgende Jobplanen ${ }^{20}$. I 2008 var dette tal på 2624 personer.

Inkluderet i tallet er de personer, som er kommet til Danmark via Positivlisten eller Greencard-ordningen, og som derved har skullet dokumentere særlige uddannelsesmæssige kvalifikationer enten i kraft af en lang videregående uddannelse eller en mellemlang uddannelse (bachelor eller professionsbachelor). Inkluderet er også de udenlandske arbejdstagere, som er ankommet via Beløbsordningen, hvor der ikke er noget krav til særlig uddannelse eller kvalifikationer. Det samlede tal i diagram 1 kan således også indkludere personer, der ikke nødvendigvis har særlige uddannelsesmæssige kvalifikationer, men som har fået tilbudt et job med en vis indkomst. Endvidere er der et mindre antal personer, der kunne betegnes som særligt kvalificerede, men som ikke er inkluderet i det samlede antal af opholds- og arbejdstilladelser udstedt via Jobkortordningen og Jobplanen. Det gælder fx. kvalificeret arbejdskraft i introduktionsforløb, pendlere og enkelte andre, som findes registreret på anden vis. I 2008 udgjorde denne gruppe 167 personer. Endvidere er der arbejdstagere, der registreres under „Lønarbejde og selvstændigt erhvervsdrivende“, som i teorien også kan være kvalificeret arbejdskraft. Denne gruppe var i 2008 på 3109 personer.

Diagram 1 viser, at antallet af opholds- og arbejdstilladelser gennem Jobkortordningen og Jobplanen har været stigende siden ordningernes indførsel i 2002. Særligt inden for de sidste tre år har udviklingen taget fart, og det billede tegner ikke til at ændre sig i 2009. Således er der i de første syv måneder af 2009 via Jobplanen udstedt 2208 arbejds- og opholdstilladelser. Dette er tæt på det samlede antal for hele 2008. Det stigende antal er særligt interessant i lyset af den internationale finanskrise, der har medført øget ledighed i Danmark og globalt. På trods af den omfattende krise har der forsat været et stigende antal udenlandske arbejdstagere, der har fået jobkontrakter i Danmark.

\footnotetext{
${ }^{20}$ Jobplanen træder først i kraft pr. 1.7.2007, hvorfor arbejdstagerne inden da kom via Jobkortordningen. De forskellige ordninger er beskrevet i dette kapitels første afsnit.
} 
Antal tilkomne

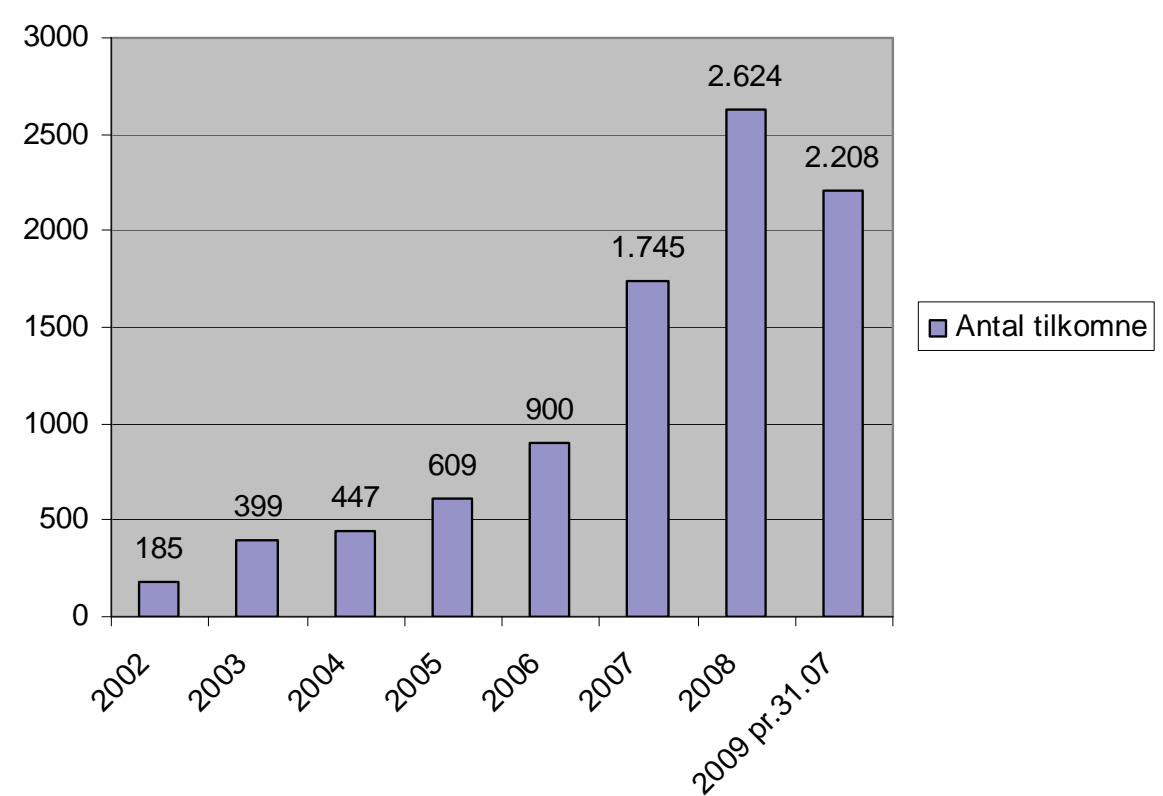

Diagram 1: Antallet af opholds- og arbejdstilladelser via Jobkortordningen og fra 1.7 2008 Jobplanen ${ }^{21}$

Den internationale finanskrise har vist sig at påvirke en lang række af brancher og stillingskategorier, men det er muligt, at der er jobområder, hvor effekten er mindre, og der fortsat er behov for arbejdskraft i Danmark. Ledigheden blandt akademikere og ingeniører ligger således stadig forholdsvis lavt, men også her har man set stigninger. ${ }^{22}$ Arbejdsgiverorganisationen DI har peget på, at den fortsatte stigning i antallet af kvalificerede udenlandske arbejdstagere, som får adgang til Danmark, skyldes, at der er en række stillinger, hvor der trods finansiel krise stadig ikke findes den rette kompetente arbejdskraft indenfor landets grænser. ${ }^{23}$ Ifølge DI's undersøgelse ved brug af eget virksomhedspanel i april 2009, hvor 2100 medlemmer blev udvalgt og 515 svarede, er der godt $27 \%$ af virksomhederne, der forventer at rekruttere i 4. kvartal i 2009. Heraf forventer lidt over halvdelen at rekruttere arbejdskraft med lang videregående uddannelse særligt inden for teknik og naturvidenskab. Ifølge undersøgelsen er det godt $14 \%$ af virksomhederne, som forventer at rekruttere efter denne type arbejdskraft, hvor ingeniører kan være repræsenterede ${ }^{24}$.

En anden forklaring på stigningen i antallet af udenlandske arbejdstagere, der har fået jobkontrakter i Danmark, er, at særligt sænkningen af Be-

${ }^{21}$ Kilde: Tal fra Udlændingeservice på baggrund af publikationerne „Tal på Udlændingeområdet 30.04.09“ og „Kvartalstal: Overblik over alle meddelte opholdstilladelser mv. for årene 2002-2007 samt jan.-sep. 2008“ samt senere eftersendte tal for første halvår af 2009 fra Udlændingeservice

${ }^{22}$ AE analyse 31. juli 2009

${ }^{23}$ DI Opinion, 14/8 2009

${ }^{24}$ Tallene er fra DI’s undersøgelse af virksomhedernes rekrutteringsforventninger til 4. kvartal 2009, der indgik som en del af Virksomhedspanelundersøgelsen fra foråret 2009. Panelet består af 2100 medlemsvirksomheder, der fire gange årligt besvarer spørgsmål. 
løbsordningen i forbindelse med indførslen af Jobplanen har gjort det administrativt nemmere for arbejdsgivere at rekruttere udenlandsk arbejdskraft. Under den tidligere Jobkortordning var Positivlisten den helt centrale ordning, og der blev i 2007 således udstedt 1624 opholds- og arbejdstilladelser via Positivlisten og kun 121 via Beløbsordningen. Dette blev ændret med Jobplanen og sænkningen af beløbsgrænsen, hvorfor der i 2008 bliver udstedt 1243 tilladelser via Beløbsordningen og kun 259 via Positivlisten. Dette er til trods for, at Positivlisten i 2008 blev udvidet med en lang række stillingskategorier. Tallene peger på, at mange vælger at benytte Beløbsordningen alternativt til Positivlisten og det er således muligt, at regelændringen har ført til, at flere virksomheder simpelthen har haft mulighed for at tilbyde jobkontrakter til udenlandske arbejdstagere. Der er dog kun statistik tilgængeligt fra en kort periode efter ændringerne af ordningerne, hvorfor det ikke er muligt at vurdere den fulde effekt. En sidste delforklaring kan endvidere være, at det først er nu, de udenlandske arbejdstagere og virksomhederne i Danmark er blevet gjort bekendte og fortrolige med ordningerne, hvorfor de gør større brug af dem.

Sammenholdt med Beløbsordningen har det været relativt få, der er kommet til Danmark via Koncernordningen. I perioden januar-august 2009 var tilgangen på 104 personer. DI mener, at det lave antal skyldes indretningen af ordningen, der primært gør den relevant for de store virksomheder med regulære udviklingsafdelinger, der rutinemæssigt flytter ansatte fra land til land. Fordelen ved at bruge Koncernordningen er, hvis virksomheden har en udenlandsk medarbejder, der er ansat i Danmark og så skal rejse ud og arbejde i et andet land, og derefter rejse tilbage til Danmark efter en kortere periode. I Danmark mister man normalt opholdstilladelsen, hvis man rejser væk i mere end seks måneder, men dette problem opstår ikke, når man benytter Koncernordningen, hvor man kan rejse væk og komme tilbage inden for en periode på tre år.

I 2008 blev der udstedt 156 opholdstilladelser via Greencard-ordningen. Fra starten og frem til midten af 2009 har man, som tidligere nævnt, modtaget flere end 4000 Greencard-ansøgninger, hvilket er en markant stigning for denne ordning. Hvor mange tilladelser, som reelt vil udstedes i 2009 afhænger af kvaliteten af ansøgere i forhold til ordningens pointsystem. Imidlertid afspejler den øgede tilgang af ansøgninger sandsynligvis den øgede ledighed globalt. Derudover er det også muligt, at stigningen kan begrundes i de tiltag, Danmark har taget, for at markedsføre Danmark som et arbejdsland i udlandet. Dette vil dog kræve nærmere undersøgelse, for endeligt at kunne konkluderes.

\subsubsection{Mobilitet blandt ingeniører}

Nedenstående diagram viser antallet af ingeniører fra tredjelande, der har fået opholdstilladelse via Jobkortordningen og Jobplanen. Tabellen viser, at antallet er svingende siden ordningernes indførsel i 2002, men de sidste 
tre år er der sket en støt stigning indenfor denne faggruppe. Højdepunktet er 2008, hvor Jobplanen træder i kraft - den udvider mulighederne ved bl.a. en lavere sats på Beløbsordningen. Det er imidlertid også i 2008, at finanskrisen bryder ud, og da de fagspecifikke tal for 2009 ikke er tilgængelige, er det ikke muligt at vide, om antallet er faldet i 2009. Det mest sandsynlige er dog, at ingeniørerne følger udviklingen for den kvalificerede arbejdskraft generelt, hvorfor der også for denne gruppe udstedes flere opholdstilladelser i 2009.

Tilgang af ingeniører

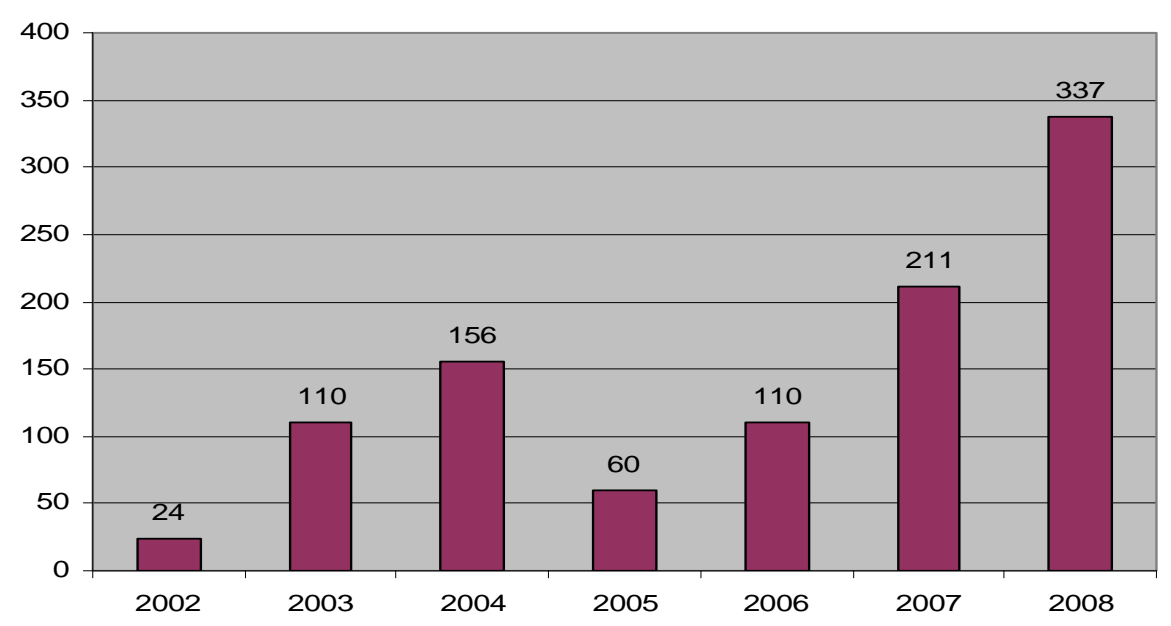

Diagram 2: Antallet af ingeniører fra tredjelande via Positivlisten og Beløbsordningen ${ }^{25}$

Også for ingeniørerne har sænkningen af beløbsgrænsen ændret deres mønster i benyttelsen af ordningerne. I første halvdel af 2008 blev der udstedt 145 tilladelser via Positivlisten, mens der i anden halvdel efter Jobplanens indførsel kun blev udstedt 36 tilladelser. Til gengæld kom der i samme halvår 156 ingeniører ind på Beløbsordningen, hvor der dengang grænsen var på 450.000 kr. kun samlet kom 121 kvalificerede med alle typer uddannelser. Tallene peger på, at væksten i Beløbsordningen sker på bekostning af Positivlisten. Samlet set vokser antallet af ingeniører dog via de to ordninger.

Diagram 2 afspejler de officielle tal på udstedelser fra Udlændingeservice, men kun for tilladelser via Positivlisten og Beløbsordningen. Derfor kan der godt være flere ingeniører i Danmark, der har fået arbejdstilladelse via Koncernordningen eller som har fået Greencard. Det er ikke registreret, hvor mange af disse tilladelser der er givet til ingeniører. Ifølge IDA er der derudover en række ingeniører, der ikke kommer til gennem Jobkortordningen/Jobplanen, men finder vej hertil på anden vis fx. som medfølgende ægtefælle.

\footnotetext{
${ }^{25}$ Kilde: Tal fra Udlændingeservice på baggrund af publikationerne „Tal og fakta 07“ og „Tal og fakta $08^{\prime \prime}$
} 
Endelig skal det nævnes, at der ifølge IDA er en vis udveksling mellem erhvervsgrupperne ingeniører og it-specialister. Sidstnævnte er et FTF/HK-område, og arbejdstagerne har ikke nødvendigvis en kandidatuddannelse, men typisk en mellemlang uddannelse på bachelorniveau. Derfor er lønnen i gennemsnit noget lavere end for den klassiske ingeniør. IDA formoder, at der er en større gruppe ingeniøruddannede, der kommer ind gennem it-specialist-kategorien. Deres faktiske arbejde er som ingeniører, men de ansættes af virksomhederne som it-specialister fordi de dermed kan tilbydes en lavere løn. IDA underbygger sin påstand, idet de ser en tydelig substitution imellem de to stillingskategorier. I perioden 15. juli 2003-15. juni 2004 var it-specialister ikke omfattet af Jobkortordningen efter foranledning fra fagforbundene PROSA (Forbundet af IT-professionelle) og HK (Handels- og Kontorfunktionærernes Forbund), der oplevede stigende ledighed blandt it-specialister. I 1 . og 2. kvartal af 2004 var antallet af tilladelser til ingeniører således 118, mens der selvsagt ingen it-specialister kom til. I 3. og 4. kvartal faldt antallet af ingeniører så igen til samlet 38 tilladelser, mens antallet af tilladelser til it-specialister nåede op på 160 alene i de to kvartaler.

\begin{tabular}{|c|c|c|c|c|c|c|c|c|c|c|}
\hline Årstal & 2002 & 2003 & $\begin{array}{l}2004 \\
1 . \mathrm{kv}\end{array}$ & $\begin{array}{l}2004 \\
\text { 2. kv }\end{array}$ & $\begin{array}{r}2004 \\
3 . \mathrm{kv}\end{array}$ & $\begin{array}{r}2004 \\
4 . \mathrm{kv}\end{array}$ & 2005 & 2006 & 2007 & 2008 \\
\hline Ingeniører & 24 & 110 & 67 & 51 & 12 & 26 & 60 & 110 & 211 & 337 \\
\hline it-specialister & 87 & 107 & 0 & 0 & 13 & 147 & 447 & 688 & 1207 & 1318 \\
\hline
\end{tabular}

Tabel 1 viser dermed, at da det ikke var muligt, at benytte Positivlisten som it-specialist, steg antallet af tilladelser til ingeniører. Dette kan tyde på, at der sker en form for substitution imellem de to stillingskategorier, fordi det er mere favorabelt for virksomhederne at ansætte folk til en lavere løn som it-specialist.

Det er generelt begrænset, hvor meget data der har været tilgængeligt på området, hvilket har stået noget i kontrast til den politiske interesse, der har været for at rekruttere udenlandsk arbejdskraft. Der har således siden 2001 været et kontinuert politisk fokus på den langsigtede nødvendighed af at tiltrække kvalificeret arbejdskraft til Danmark, uden at man dog har kunnet dokumentere det faktiske antal af udenlandske arbejdstagere der opholder sig i landet og deres særlige kvalifikationer og ansættelse. Igennem en årrække har man opgjort tilgangen af udenlandsk arbejdskraft til Danmark i form af tilkendegivne opholds- og arbejdstilladelser. Tallene opgøres og offentliggøres af Udlændingeservice, mens Arbejdsmarkedsstyrelsen også gør dem tilgængelige via deres Nøgletalssystem. Fra starten af 2010 er Nøgletalssystemet som tidligere nævnt dog blevet væsentligt udvidet. Arbejdsmarkedsstyrelsen kan nu samkøre til-

\footnotetext{
${ }^{26}$ Kilde: Tal fra Udlændingeservice på baggrund af publikationerne „Nøgletal på udlændingeområdet 2003“, „Tal og fakta 04“, 05, 06, 07, 08 samt kvartalsudtræk fra 2004
} 
gangstallene med oplysninger fra SKAT’s E-indkomst-register således, at man på månedsbasis kan opgøre den faktiske bestand af udenlandske arbejdstagere i Danmark. Bestandstallene kan yderligere fordeles på opholdsgrundlag, længde af ophold, branche, nationalitet og geografisk område. Det udvidede Nøgletalssystem er på den baggrund blevet stærkt forbedret i forhold til at kunne overvåge rekrutteringsindsatsen, og man vil således fremover kunne sammenligne, hvor mange der tager til Danmark for at arbejde, om de bliver, og hvor længe de bliver. Imidlertid går opgørelsen af bestandstallene for den arbejdskraft, som har fået adgang på særordningerne efter jobplanen fra 2008, jo kun få år tilbage, og det giver derfor endnu ikke megen mening at sammenligne tallene med henblik på at vurdere, hvor mange af de ankomne på særordningerne efter 2008, der vælger at blive i længere tid i Danmark. Da der er tale om en noget grov brancheinddeling, er det heller ikke muligt at konstatere antallet af udenlandske ingeniører, der arbejder og opholder sig i Danmark i øjeblikket.

\subsubsection{Rekrutteringsinitiativer særligt i forhold til ingeniører}

Særligt arbejdsgiver- og lønmodtagerorganisationerne på ingeniørområdet har i Danmark presset på for at fremme Danmarks aktive rekrutteringsinitiativer. De danske myndigheder har haft et bredere rekrutteringsfokus end blot ingeniører, dog har udviklingen i de rekrutteringsinitiativer, som er taget, haft præg af særligt at skabe gode rammer for rekrutteringen af ingeniører. Ingeniører optrådte således allerede fra starten på Positivlisten over professioner, som har særlig let adgang til Danmark. Endvidere har placeringen af det første udenlandske Work in Denmark-center i New Delhi blandt andet haft baggrund i at få adgang til Indiens veluddannede ingeniører.

DI har den største andel af medlemsorganisationer med udenlandske ansatte, og som sådan har organisationen været meget aktiv $i$ at fremme rekruttering af blandt andet ingeniører. På lønmodtagersiden har Ingeniørforbundet i Danmark (IDA) selvstændigt spillet en særlig rolle i samarbejde med Håndværksrådet og fagforbundet Dansk Metal. Et samarbejde, som således rækker ind i LO-organisationen, og som ikke har fortilfælde blandt andre organisationer. Dette samarbejde mundede i 2005 ud i en fælles præsentation af en undersøgelse af virksomheders motiver til udflytning af opgaver til udlandet og de beskæftigelsesmæssige konsekvenser.

Herudover har både DI og IDA lagt stor vægt på at fremme smidiggørelse af reguleringen omkring rekrutteringen, og at Danmark brandes bedre som et arbejdsland i udlandet. Dette har blandt andet konkret mundet ud i den ovenfor nævnte Jobambassadørordning, hvor privatpersoner, der er ansat i udlandet agerer som ambassadører for Danmark på det udenlandske arbejdsmarked. Aktivitetsniveauet blandt ordningens jobambassadører har været svingende, og det er endvidere svært at måle de 
konkrete resultater af ordningen. Som følge af finanskrisen fra 2008 og et heraf midlertidigt manglende jobudbud i Danmark har man dæmpet indsatsen, men man forventer at genoptage arbejdet på længere sigt.

For at lette rekrutteringen af udenlandsk arbejdskraft har IDA også taget en række selvstændige initiativer. I 2003 bidrog IDA til gennemførslen af en undersøgelse, hvor hovedresultatet var, at det ikke er særligt attraktivt for højtkvalifcerede østeuropæiske arbejdstagere at søge til Danmark. ${ }^{27}$ Rapporten pegede på, at de østeuropæiske arbejdstagere ikke har særligt godt kendskab til Danmark og de danske virksomheder. IDA har siden medvirket til at gennemføre en større undersøgelse, sidst i 2006, hvor det igen slås fast, at Danmark ikke er godt kendt i udlandet, samt at dem, som endelig kommer hertil, oplever visse barrierer i forhold til især sprog og sociale relationer. ${ }^{28}$ Danmark opleves som et lukket land, danskerne er svære at komme ind på og den medfølgende ægtefælle kan ikke falde til. Konsekvensen er, at arbejdstageren vælger at rejse hjem igen. IDA har i forlængelse heraf haft stort fokus på, hvad der skal til for at gøre Danmark attraktivt som arbejdsland både i henhold til rekruttering, men også på længere sigt fastholdelse. I forhold til myndighederne så IDA gerne, at man i Danmark søgte mere inspiration hos Canada, hvor der er udarbejdet et reelt velkomstapparat, og nye arbejdstagere bliver modtaget med en drejebog for mødet med myndighedsjunglen samt tiltag, der hjælper den ofte medfølgende familie. IDA har også selv udformet en produktpakke til de forskellige faser; pre-rekruttering, selve rekrutteringen, "Velkommen til Danmark"-arrangementer og endeligt opfølgnings-arrangementer. Initiativer, der inddrager sociale og faglige netværk, familie og børn. Dermed har de som nogle af de første haft fokus på at kombinere aktiv rekruttering i udlandet med fastholdelsesinitiativer i Danmark.

\subsubsection{Fremtidigt behov for ingeniørkompetence}

I en samlet vurdering af den fremtidige efterspørgsel af ingeniører må en række faktorer inkluderes. Dels må man se på efterspørgslen blandt virksomhederne både på specifikke kompetencer og stillingstyper, dels må man tage højde for ændringer i udbuddet på kort og på lang sigt i form af ledig arbejdskraft og antallet af nyuddannede.

Der findes relativt lidt dokumentation for arbejdskraftbehovet i Danmark, hvis man ønsker at sætte tal på det fremtidige behov for særlige uddannelses- og kompetencegrupper såsom ingeniører. Derimod findes der i kraft af Arbejdsmarkedsstyrelsens halvårlige rekrutteringsundersøgelse god dokumentation for, hvilke stillingstyper virksomhederne i givne perioder oplever rekrutteringsproblemer omkring.

Der har været bred enighed om, at man i Danmark under højkonjunkturen frem til finanskrisen i slutningen af 2008 har oplevet en stærk nu-

\footnotetext{
${ }^{27}$ PLS Rambøll Management 2003

${ }^{28}$ Oxford Research 2007
} 
merisk efterspørgsel efter ingeniører, hvilket har været afspejlet i en historisk lav ledighed blandt ingeniører i starten af 2008. Den numeriske efterspørgsel kan blive indhentet af lavkonjunkturen, der har sat ind fra slutningen af 2008, men grundet afgang fra arbejdsmarkedet og de små årgange vil effekten af en lavkonjunktur på beskæftigelsen blandt ingeniører sandsynligvis være begrænset på længere sigt. I første halvår af 2007, hvor Danmark var på toppen af højkonjunkturen, havde virksomheder ifølge Arbejdsmarkedsstyrelsens rekrutteringsundersøgelse rekrutteret forgæves til 58.000 stillinger på landsplan. Dette er i første halvår 2009 reduceret til 8000 stillinger. ${ }^{29}$ Arbejdsmarkedsstyrelsens rekrutteringsundersøgelse fra første halvår $2009^{30}$, hvor 20.316 virksomheder blev spurgt om deres rekrutteringsbehov og 14.112 svarede, melder om ubesatte ingeniørstillinger på forskellige ingeniørtyper.

Der har været nogen kritik af fortolkningen af rekrutteringsundersøgelsens opgørelse af behovet efter arbejdskraft. Arbejderbevægelsens Erhvervsråd har påpeget, at tallene ikke kan tolkes som ubesatte stillinger, men blot siger noget om antallet af stillinger, som virksomheder på et givet tidspunkt har rekrutteret forgæves til. ${ }^{31}$ Kritikken har blandt andet påpeget, at stillingerne siden hen kan være blevet besat med anden arbejdskraft. Arbejdsmarkedsstyrelsens undersøgelse tager dog i en vis grad højde herfor ved at spørge virksomhederne, om de på undersøgelsestidspunktet har færdiggjort rekrutteringsprocessen. Den anden del af kritikken, som går på, at størrelsen af rekrutteringsproblemet afhænger af længden på undersøgelsesperioden har også en vis relevans. Først når man har gennemført undersøgelsen ad flere omgange henover en fuld konjunkturperiode, kan man danne sig et fuldt billede af, hvilke stillingstyper der også vil være ubesatte i en lavkonjunktur, hvor der generelt er høj arbejdsløshed. Man har reelt forsøgt at tage højde herfor ved at ligge tallene fra Arbejdsmarkedsstyrelsens rekrutteringsundersøgelse sammen med en stor mængde data i Arbejdsmarkedsbalancemodellen, som blandt andet inkluderer tallene for ledigheden i Danmark. På nuværende tidspunkt er Arbejdsmarkedsbalancemodellen den bedst udviklede statistiske indikator på, hvilke stillingstyper der oplever mangel på arbejdskraft, og hvilke stillingstyper der oplever særlige ubalancer.

Ifølge Arbejdsmarkedsbalancen for foråret 2009 er det få ingeniørstillinger, hvor der fortsat er særlige rekrutteringsproblemer og ekstraordinær lav ledighed. Det gælder anlægsingeniør, bygningsingeniør, maskiningeniør og til en vis grad it-ingeniører. Af de konkrete tal fremgår det klart, at den finansielle krise har haft stor indflydelse på virksomhedernes rekruttering. I efteråret 2008 var det således på landsplan 170 it-ingeniør-stillinger, der blev rekrutteret forgæves til, mens man i foråret 2009 kunne registrere under 50 it-ingeniør-stillinger, der ikke kunne rekrutteres til. Mangel på

\footnotetext{
${ }^{29}$ Arbejdsmarkedsstyrelsen, Rekruttering, 1. halvår 2009

${ }^{30}$ Arbejdsmarkedsstyrelsen 2009b. Arbejdsmarkedsstyrelsens rekrutteringsundersøgelse er en del af Arbejdsmarkedsbalancemodellen, som de fire beskæftigelsesregioner leverer input til.

${ }^{31}$ AE analyse november 2008
} 
udbudt arbejdskraft til de her nævnte typer af ingeniørstillinger optræder primært i beskæftigelsesregion Hovedstaden-Sjælland og Syddanmark. For it-ingeniører er der faktisk et overskud af arbejdskraft i Nordjylland, mens man oplever særlige rekrutteringsproblemer i Hovedstaden-Sjælland. Itkonsulenter, softwareudviklere, it-projektledere - stillinger, som kunne tænkes at blive besat af ingeniører - er fortsat på top 25 over de stillingstyper, som virksomhederne i Hovedstaden og på Sjælland har forsøgt at rekruttere efter forgæves, men andre steder i Danmark ser det noget anderledes ud.

Ser man på udviklingen i udbuddet af ingeniørarbejdskraft, har ledigheden de seneste år blandt ingeniører været bemærkelsesværdig lav. Ledigheden blandt ingeniører var således i 2008 under 1,5 \%, men lå i juli 2009 på 3,2 \% og er som følge af lavkonjunkturen og den finansielle krise stigende. ${ }^{32}$ Dimittendarbejdsløsheden steg fra $12 \%$ i januar 2009 til $24 \%$ i juli 2009. Det samlede antal af ledige ingeniører har imidlertid, ifølge IDA's analyser, været svagere stigende under finanskrisen i 2008/2009, end efter it-boblen brast i 2000. Endvidere påpeger IDA, at der til stadighed vil være særlige specialiseringer af ingeniører, som der vil være mangel på fremover. It-branchen har således meddelt, at deres medlemmer i mindre omfang oplever stigende ledighed som følge af krisen, dog er der som illustreret ovenfor klare tegn på, at manglen på itarbejdskraft er blevet væsentlig mindre.

Samlet set tyder tallene ikke på en væsentlig nuværende mangel på ingeniører, men på længere sigt står Danmark uden tvivl over for en demografisk udfordring, som også rammer ingeniørområdet i og med, at en stor gruppe går på pension i løbet af de næste 4-6 år, hvorefter de små årgange tager over. Problemet er særligt stort blandt ingeniører i den offentlige sektor, hvor hver fjerde stopper, og IDA vurderer på baggrund af medlemsundersøgelser, at denne sektor generelt ikke opfattes som den mest attraktive at træde ind i. Med udgangspunkt i den aktuelle uddannelsesadfærd, den historiske trend for efterspørgsel efter arbejdskraft og skøn over den økonomiske udvikling vurderer IDA, at man allerede i 2015 vil mangle 7600 ingeniører, mens man på lidt længere sigt i 2025 vil mangle mellem 9000 (forsigtigt skøn) og 20.000 (maksimalt skøn) ingeniører fordelt på både det private og offentlige arbejdsmarked. ${ }^{33}$ Antallet af ingeniører i den danske arbejdsstyrke forventes kun at stige marginalt de kommende år, mens det forventes at efterspørgslen vil vokse betydeligt mere, og det vil føre til mangel på ingeniører ${ }^{34}$. Derudover er der en række specialområder, som Danmark ikke uddanner til. For at kunne fastholde virksomheder og især udviklingsafdelingerne i Danmark anser IDA det derfor nødvendigt, at Danmark kan tiltrække den nødven-

\footnotetext{
${ }^{32}$ IAK nøgletal

${ }^{33}$ IDA, juni 2009

${ }^{34}$ Udbuddet af arbejdskraft er baseret på fremskrivning af de seneste 2008-tal for optag og udbud af diplom- og civilingeniører samt tekniske ph.d.er, mens efterspørgsel af ingeniører tager udgangspunkt i Finansministeriets 2015-plan for forventninger til beskæftigelse og brancheudvikling.
} 
dige ekspertise, og da der hele tiden sker en specialisering indenfor faget, vurderes det, at behovet for kompetent udenlandsk arbejdskraft kun vil øges.

\subsection{Nationale udfordringer i rekrutteringspolitikken}

\subsubsection{Regulering}

Det helt grundliggende princip for at opnå arbejds- og opholdstilladelse i Danmark for tredjelandsborgere er, at der er tale om særlige beskæftigelsesmæssige eller erhvervsmæssige hensyn. For at lette adgangen for særlig kvalificeret arbejdskraft har man lavet en række særordninger. Positivlisten, Beløbsordningen og Greencard-ordningen er de tre væsentligste ordninger, der har spillet en rolle for rekrutteringen og den politiske diskussion.

Langt de fleste udenlandske tredjelandsborgere, der kom til Danmark i perioden 2002-2007 på en af særordningerne, fik adgang via Positivlisten. Ved sænkningen af Beløbsordningen i starten af 2008 skiftede ansøgningsfrekvensen til denne ordning. Som for Positivlisten gælder det for Beløbsordningen at løn og ansættelsesvilkår skal være sædvanlige efter danske vilkår. Kriterierne for adgang via Beløbsordningen hviler imidlertid primært på det lønniveau, som arbejdsgiver tilbyder, og man er derfor ikke nødsaget til at skulle dokumentere uddannelse og kvalifikationer. Beløbsordningen er den mest simple ordning og lader til i vidt omfang at have erstattet Positivlisten. Greencard-ordningen har været brugt i relativt begrænset omfang, men har vist sig særlig interessant for udenlandske statsborgere, der ønsker at tilbyde deres arbejdskraft til virksomheder i Danmark og brugen af ordningen er steget i 2009. Den pludselige tilgang i ansøgninger har imidlertid voldt en del problemer i forhold til at få sagerne oplyst og materialet behandlet således, at man kan leve op til servicemålene for sagsbehandlingstiden. Greencard-ordningen er samtidig den eneste ordning, der gør det muligt for en udenlandsk statsborger at tilbyde sin arbejdskraft uafhængigt af et konkret jobtilbud, og på den baggrund har den også været den politisk mest omstridte ordning.

\subsubsection{Strategier}

Et væsentligt element i den danske tilgang til regulering af kvalificeret arbejdskraft er, at loven gør det muligt at justere ordningerne undervejs, så den så vidt muligt afspejler aktuelle behov på arbejdsmarkedet. Således justeres Positivlisten løbende i forhold til balancen på arbejdsmarkedet. Man har også mulighed for politisk at vælge at justere lønkravet i Beløbsordningen og indretningen af pointsystemet, efter hvilket man vurderer ansøgninger om Greencard. Udviklingen i det danske regelværk og rekrutteringsinitiativer for højtkvalificeret arbejdskraft fra tredjelande 
har siden 2001 bevæget sig fra ensidig fokusering på det adgangsgivende regelværk til at fremme aktiv rekruttering og branding af Danmark i udlandet. Der er foregået en væsentlig udbygning af myndighedernes service i form af de tre nye Work in Denmark-centre, der bredt skal medvirke til at formidle udenlandsk arbejdskraft og bistå virksomhedernes rekruttering. I løbet af 2008 er der endvidere kommet et tredje ben til i strategien, hvor man fokuserer på fastholdelse, når arbejdskraften først er kommet til landet. Måling af strategiens succes stiller krav til kvaliteten af overvågningen af udbud og efterspørgsel på arbejdskraft både på kort og på lang sigt, og hvem der egentlig opholder sig og arbejder i Danmark. Arbejdsmarkedsbalancen indgår her som et vigtigt styringsredskab i forhold til at vurdere, hvor der kan være særlige rekrutteringsproblemer. Som sådan bærer den danske strategi til rekruttering af udenlandsk arbejdskraft præg af at være primært efterspørgselsdrevet. Frem til starten af 2010 har det dog ikke været muligt at konstatere, hvor mange udenlandske arbejdstagere, der arbejdede i Danmark med hvilke kvalifikationer. Dette er delvist blevet afhjulpet af Arbejdsmarkedsstyrelsens udarbejdelse af bestandstal, hvorved man i dag har mulighed for at overvåge, hvor mange som bor og arbejder i Danmark, hvor de opholder sig, og hvor længe den udenlandske arbejdskraft bliver, det er dog fortsat en udfordring at identificere, hvilke specifikke kompetencer den udenlandske arbejdskraft kommer med.

Arbejdsgiverorganisationerne og de akademiske lønmodtagerorganisationer har presset på for både regelforenkling, mere aktiv rekruttering og markedsføring af Danmark og bedre fastholdelse. Aftalen mellem parterne DA og LO på det private arbejdsmarked vidner yderligere om et vist fælles fodslag blandt arbejdsmarkedets parter omkring nødvendigheden af en øget indsats for rekruttering af kvalificeret arbejdskraft fra udlandet på længere sigt. Især LO har dog understreget, at dette skal ledsages af bedre opkvalificering af allerede eksisterende arbejdskraft og en fornuftig integrationsindsats af de nye arbejdstagere.

\subsubsection{Realiteter}

Der kommer stadig relativt få kvalificerede udlændinge fra tredjelande til Danmark, selvom alt tyder på, at tendensen er stigende. Det stigende antal, som især ankommer via Beløbsordningen, vidner om, at regelforenkling synes at have skubbet til udviklingen. Næsten halvdelen af de, der fik tilladelse via ordningerne under Jobplanen i 2008, er registrerede som it-specialister, mens godt en syvendedel af tilladelserne er registrerede til ingeniører.

På kort sigt har den hurtige konjunkturændring som følge af finanskrisen vist, at virksomhederne er meget påholdende i forhold til rekruttering, når tiderne er usikre, og det er således svært at vurdere det aktuelle arbejdskraftsbehov i midten af 2009. Meget tyder dog på, at såfremt de 
langsigtede prognoser holder, står Danmark over for en reel udfordring i forhold til at skaffe den fornødne ingeniørarbejdskraft i fremtiden, når de store årgange går på pension. Arbejdsgiverorganisationer og fagforeninger peger også på, at den stigende specialisering af produktionen gør det nødvendigt, at virksomheder kan tiltrække særlige kvalifikationer til Danmark, såfremt man ønsker at fastholde virksomhederne i landet.

Simple adgangsregler såsom Beløbsordningen har givet resultater i forhold til at flere danske virksomheder rekrutterer udlændinge. Aktiv markedsføring af Danmark via Work in Denmark-centret i Delhi, Indien har også givet resultater i forhold til mange henvendelser fra lokalbefolkningen. Matchingen mellem ansøgere og virksomheder har dog ikke kunnet lade sig gøre, hvilket vidner om, at efterspørgslen på kvalificeret udenlandsk arbejdskraft i øjeblikket er afdæmpet. Samtidig har kvalifikationsniveauet blandt en del af den udbudte arbejdskraft til centret været lavere end ønsket. Endelig har flere praktiske problemer i forhold til at vurdere kvalifikationer og verificere eksamenspapirer meldt sig.

I Danmark har både arbejdsmarkedsorganisationer og myndigheder gennemført undersøgelser blandt kvalificerede udlændinge, som arbejder i Danmark. Målet har både været at afklare, hvad der tiltrækker kvalificeret arbejdskraft, og hvad der skal til for at fastholde den i landet. Undersøgelserne peger på, at aktiv markedsføring af Danmark er nødvendigt for at øge rekruttering, men at det kræver viden om de udenlandske arbejdsmarkeder i forhold til at målrette rekrutteringen mod de rette grupper. Undersøgelserne peger endvidere på, at regelforenkling i forhold til udenlandske arbejdstagere, bedre formidling fra det offentlige på flere sprog og social integration på arbejdsplads og i lokalsamfund er afgørende for at fastholde arbejdskraften i Danmark. Der synes at være et solidt vidensgrundlag for at tage nye initiativer i den retning, men grundet pres på de offentlige finanser, en stigende arbejdsløshed og en ugunstig politisk situation i forhold til at lempe adgangen til Danmark for borgere fra tredjelande, er der sandsynligvis ikke incitament nok til yderligere offentlige investeringer $\mathrm{i}$ at udvide rekrutterings- og fastholdelsesstrategien foreløbig.

\section{Kilder og referencer}

Kilder:

Kvalitative interview gennemført med: Fuldmægtig Lisbeth Møller Nielsen, Beskæftigelsesministeriet

Chefkonsulent Tine Gram, Arbejdsmarkedsstyrelsen, Metodeudvikling og international rekruttering

Chefkonsulent Finn Krogh Jørgensen, Ingeniørforeningen IDA

Chefkonsulent Martin Steen Kabongo, DI

Konsulent Jens Erik Zebis Sørensen, DI
Supplerende samtaler eller skriftlige svar fra reprcesentanter fra:

Akademikernes Centralorganisation (AC)

Dansk Arbejdsgiverforening (DA)

Dansk Erhverv (DE)

Landsorganisationen i Danmark (LO)

Ministeriet for Flygtninge, Indvandrere og Integration, Erhvervsenheden

Prosa, Forbundet af IT-professionelle

Udlændingeservice

Work in Denmark Center i New Delhi 
Work in Denmark Center, Vest Work in Denmark Center, Øst Ikke udgivet:

Faktuel rapport om de nordiske landes udlændingeretlige regler vedrørende arbejdskraftsindvandring med fokus på højt kvalificeret udenlandsk arbejdskraft, udarbejdet af arbejdsgruppen om arbejdskraftsindvandring for Den Nordiske Samrådsgruppe på Højt Niveau for Flygtningespørgsmål. 10 . juni 2009, Ministeriet for Flygtninge, Indvandrere og Integration, Erhvervsenheden

Deloitte (November 2008) „International Rekruttering. Barrierekatalog“" Task force til identifikation og forenkling ved rekruttering af udenlandsk arbejdskraft.

Referencer:

13 Punktsplanen, Notat Beskæftigelsesministeriet

Aftale om en jobplan, Februar 2008.

Aftale mellem regeringen (Venstre og Det Konservative Folkeparti), Dansk Folkeparti, Det Radikale Venstre og Ny Alliance

Arbejderbevægelsens Erhvervsråd (AE) analyse 27. november 2009: „Myter og Realiteter om ubesatte stillinger“ af Jes Vilhelmsen og Frederik I. Pedersen

Arbejderbevægelsens Erhvervsråd (AE) analyse 31. juli 2009: „Krisen spreder sig langsomt men sikkert på arbejdsmarkedet" af arbejdsmarkedsøkonom Erik Bjørsted

Arbejdsmarkedskommissionen (2009) „Velfærd kræver arbejde“. Endelig Rapport, august 2009. Albertslund: Schultz Grafisk

Arbejdsmarkedsstyrelsen (2009a) „Arbejdsmarkedsoverblik 2. halvår 2009“ AMS Rapport

Arbejdsmarkedsstyrelsen (2009b) „Rekruttering 1. halvår 2009“ AMS Rapport

Arbejdsmarkedsstyrelsen m.fl. (2008) International Rekruttering- løsningskatalog. København, Deloitte. November 2008.

Arbejdsmarkedsstyrelsen (2007) „Styring af regionalt statsligt niveau og beskæftigelsesindsatsen“. Notat af 9. november 2007

Bekendtgørelse af Udlændingeloven (LBK nr. 808 af 08/07/2008)
Beskæftigelsesministeriet (2009) Konjunktur og arbejdsmarked, uge 24 , 8.-12. juni 2009

Council Directive 2009/50/EC of May 252009

Dansk Institut for Internationale Studier - DIIS (2008): „De danske forbehold over for den europæiske union. Udviklingen siden 2000“. DIIS Rapport, København: Dansk Institut for Internationale Studier.

DI Opinion 14-8-2009: Udenlandsk arbejdskraft stadig en væesentlig del af løsningen ved Jens Erik Zebis. http://di.dk/OPINION

IDA (2009): „Prognose for ingeniørmangel“ IDA Analyse juni 2009

IDA (2006): „Sådan løser vi ingeniørmanglen. 10 forslag til flere ingeniører“. Oktober 2006

IDA Nyheder 6-7-2009: „Ledigheden blandt dimittender eksploderer“ http://ida.dk/News/Sider/Ledighedenb landtdimittendereksploderer.aspx Ingeniørernes Arbejdsløsheds Kasse (IAK), Nøgletal, juli 2009

Folketinget, 10. april 2008. Høringsnotat L 132. Notat om de indkomne høringssvar vedrørende lovforslag nr. L 132 om ændring af udlændingeloven (Rekruttering af udenlandsk arbejdskraft m.v.)

Kvartalstal på udlændingeområdet (excell-fil) - download fra nyidanmark.dk

Landsorganisationen i Danmark (LO) og Dansk Arbejdsgiverforening (DA) „Aftale om rekruttering af udenlandsk arbejdskraft“. Februar 2008

Mailand, Mikkel (2007) „Rekruttering af udenlandsk arbejdskraft“. Notat udarbejdet på baggrund af et samarbejde mellem FAOS og Beskæftigelsesministeriets Juridiske, Arbejdsretlige og Internationale center (JAIC). FAOS Forskningsnotat 080, juni 2007

Ministeriet for Flygtninge, Indvandrere og Integration og Udlændingeservice (marts 2008). „Tal \& Fakta på udlændingeområdet 2007“. Ministeriet for Flygtninge, Indvandrere og Integration og Udlændingeservice, København 2008

Ministeriet for Flygtninge, Indvandrere og Integration og Udlændingeservice.(juni 2009). „Tal \& Fakta på udlændingeområdet 2008“. Ministeriet for Flygtninge, Indvandrere og Integration og Udlændingeservice København 2009 
Ministeriet for Flygtninge, Indvandrere og Integration og Udlændingeservice (2008) Power Point-præsentation om integration og fastholdelse af ny udenlandsk arbejdskraft ved specialkonsulent Rasmus Nygaard, 9.oktober 2008

Oxford Research (2007): „The Expat Study 2006. Udenlandske videnarbejdere i Danmark“. Oxford Research i samarbejde med The Copenhagen Post, januar 2007

PLS Rambøll Management (2003): EU's udvidelse mod øst - udfordrin- ger for det danske arbejdsmarked. København, september 2003

Regeringen (2007): „Danmark - et godt sted at arbejde“. Regeringens plan for international rekruttering. Oktober 2007. Arbejdsmarkedsstyrelsen, København

Udlændingeservice (2008): „Rekruttering af IT-specialister fra Indien“, Rapport fra fact-finding mission til New Delhi og Bangalore, Indien 4.-14. maj 2008 



\title{
3. Finland
}

\author{
Åsmund Arup Seip
}

\section{Forkortelser}

- EK - Finlands Næringsliv, arbeidsgiverorganisasjon

- $R P$ - Regeringens proposition

- Teknologiateollisuus - The Federation of Finnish Technology Industries

- Akava - den fackliga centralorganisationen för högutbildade i Finland

- TEK - Tekniikan Akateemisten Liitto, The Finnish Association of Graduate Engineers (Teknikens Akademikerförbund)

- TFiF - Tekniska Föreningen i Finland

- DIFF - Driftsingeniörsförbundet i Finland

- UIL - Uusi Insinööriliitto, Union of Professional Engineers

- KTK - Tekniikan Asiantuntijat, Union of Technical Professionals

\subsection{Nasjonale lovreguleringer av arbeidsinnvandring fra tredjeland}

\subsubsection{Dagens regelverk for arbeidsinnvandring fra tredjeland}

Gjeldende utlendingslov i Finland (Utlänningslagen) ble vedtatt i 2004. Loven etablerte et hovedprinsipp der oppholdstillatelse og arbeidstillatelse ble slått sammen til én tillatelse: oppholdstillatelse for arbeidstakere (uppehållstilstånd för arbetstagare). ${ }^{35}$ Lovens målsetting er å fremme tilgangen på arbeidskraft på en systematisk, rask og smidig måte, slik at både arbeidsgivers og arbeidstakers rettsikkerhet blir ivaretatt, og at arbeidsmulighetene for den innenlandske arbeidskraften ivaretas. ${ }^{36}$

Utenlandske arbeidstakere kan søke oppholdstillatelse for arbeidstaker når det foreligger tilbud om arbeid i Finland. Hovedregelen er at søknaden skal sendes fra utlandet, og at arbeidstakeren skal vente i utlandet til oppholdstillatelsen foreligger. Søknad om oppholdstillatelse for arbeidstaker kan også sendes inn av en finsk arbeidsgiver.

Når oppholdstillatelse skal vurderes skal man ta hensyn til tilgangen på arbeidskraft på arbeidsmarkedet, slik at de arbeidstakerne som allerede finnes på arbeidsmarkedet ikke blir skadelidende. I tillegg skal arbeidsgi-

\footnotetext{
${ }^{35}$ Tilsvarende regler er gitt for næringsdrivende (näringsidkare). Utlänningslag 30.4.2004/301, 5. kap.

${ }^{36}$ Utlänningslag 30.4.2004/301, 70 §.
} 
ver legge fram dokumentasjon på at arbeidsvilkårene stemmer over ens med lovgivningen og gjeldende kollektivavtaler. ${ }^{37}$ Dette er informasjon arbeidsgiver er pliktig i henhold til arbetsavtalslagen å gi alle arbeidstakere som ansettes for mer enn en måned. Bestemmelsen gjelder også når arbeidsgiveren er utenlandsk. ${ }^{38}$

Oppholdstillatelse for arbeidstakere gis vanligvis for arbeid innenfor en viss bransje. Arbeidstakeren kan bytte jobb innenfor den bransjen arbeidstillatelsen gjelder for.

Avgjørelsen om å gi oppholdstillatelse tas i to instanser. Først gir arbeids- og næringsetaten gjennom regionale arbets- och näringsbyråer (TE-byråer) og arbets- och näringscentralen uttalelser om søknaden ut fra arbeidskraftssynsvinkel, deretter vurderer Migrasjonsverket (Migri) om de øvrige vilkårene for oppholdstillatelse er oppfylt, og fatter den endelige beslutningen. Uttalelsen fra arbeids- og næringsetaten (arbetsoch näringsbyråer) om arbeidsmarkedet skal innholde en arbeidsmarkedsvurdering for den enkelte stillingen. I praksis utarbeider arbeids- og næringsetaten regionale retningslinjer for bransjer og yrker basert på de aktuelle arbeidsmarkedene, og dersom arbeidsløsheten er lav, blir det ikke gjennomført noen arbeidsmarkedsvurdering gjennom utlysning av stillingen i det konkrete tilfellet.

Det kan innvilges to typer tidsbegrenset oppholdstillatelse. Midlertidig oppholdstillatelse (tillfälligt uppehållstillstånd) gis for maksimum ett år av gangen. Slik oppholdstillatelse gir ikke rett til permanent oppholdstillatelse. Kontinuerlig oppholdstillatelse (kontinuerligt uppehållstillstånd) gis for maksimum fire år av gangen, og gir rett til permanent oppholdstillatelse (permanent uppehållstillstånd) etter et kontinuerlig opphold i landet i fire år uten avbrudd. ${ }^{39}$ Kontinuerlig oppholdstillatelse kan innvilges dersom det dreier seg om arbeid av vedvarende (fortgående) karakter samt for visse typer forskningsarbeid. ${ }^{40}$

Den finske Utlänningslagen har ingen bestemmelser om krav til utdanning for å kunne søke oppholdstillatelse for arbeidstakere. Loven har imidlertid noen egne bestemmelser som kommer til anvendelse for høyt kvalifisert arbeidskraft fra tredjeland.

\subsubsection{Regelverk vedrørende høyt kvalifisert arbeidskraft fra tredjeland}

Den finske Utlänningslagen har egne bestemmelser som gjelder for særskilte grupper, blant annet studenter og forskere. ${ }^{41}$ Reglene omfatter også

\footnotetext{
${ }^{37}$ Utlänningslag 30.4.2004/301, 73 §.

${ }^{38}$ Regeringens proposition till Riksdagen, RP 265/2002 rd, s. 173.

${ }^{39}$ Utlänningslag 30.4.2004/301, 56 §.

${ }^{40}$ Utlänningslag 30.4.2004/301, 47 §. Det finnes også en bestemmelse om at midlertidig eller kontinuerlig oppholdstillatelse i Finland kan innvilges til personer som har kommet til landet uten oppholdstillatelse dersom «det med tanke på utlänningen eller arbetsgivaren är ogrundat att vägra sådant uppehållstillstånd för arbetstagare... som sökts i Finland» eller «det är uppenbart oskäligt att vägra uppehållstillstånd» (49 §).

${ }^{41}$ Studenter kan etter endt utdanning søke om arbeid. Utlänningslag 30.4.2004/301, 81 a §. I 2008 ble EUs direktiv av 12 oktober 2005 (2005/71/EG) «om ett särskilt förfarande för tredjelandsmedborgares
} 
personer som innehar lederstillinger på høyeste eller mellomste nivå i et foretak, eller som utfører et oppdrag som krever spesialkompetanse. ${ }^{42}$ Disse gruppene har rett til å arbeide i Finland dersom de har en tidsbegrenset oppholdstillatelse, og trenger dermed ikke oppholdstillatelse for arbeidstaker som krever en arbeidsmarkedsvurdering. I mange tilfeller vil høyt utdannet arbeidskraft som benyttes i en avgrenset periode komme inn under denne bestemmelsen. Det kan for eksempel være ingeniører som brukes til gjennomføringen av et konkret prosjekt, eller arbeidstakere $i$ et internasjonalt konsern som har et oppdrag i konsernet. En tidsbegrenset oppholdstillatelse gir ikke rett til permanent oppholdstillatelse.

I 2006 ble Utlänningslagen endret slik at utlendinger som har avlagt eksamen i Finland kan begynne å arbeide. ${ }^{43}$

\subsubsection{Endringer av regelverket}

Da den finske regjeringen foreslo en ny utlendingslov i 2002, var en av målsettingene å forenkle lovverket slik at det ble tydelig, logisk og lett å forstå. Det skulle gi utenlandske statsborgere en rettslig stilling som var mer i samsvar med den stilling finske borgere hadde. ${ }^{44}$ Det var et mål å gi offentligheten større innsyn i regelverket og grunnlaget for beslutninger om oppholds- og arbeidstillatelse, og å redusere behandlingstiden på søknader. ${ }^{45}$ Regjeringen la også vekt på at trepartssamarbeidet knyttet til arbeidsmarkedsvurderingene ved arbeidsinnvandring ikke var godt nok regulert. ${ }^{46}$ Lovgivningen som ble vedtatt i 2004 forsøkte å bøte på disse problemene.

Praktiseringen av loven møtte etter hvert likevel kritikk. I 2006 presenterte Vanhanens første regjering et innvandringspolitisk program som skulle fremme arbeidsrelatert innvandring. I tillegg til å markedsføre Finland og styrke samarbeidet med opphavsland, ville regjeringen forenkle systemet for innvilging av oppholdstillatelser. ${ }^{47}$ Året etter, under høykonjunkturen i 2007, opprettet Migrations- och Europaminister Astrid Thors et prosjekt som skulle utrede og videreutvikle systemet for regulering av arbeidsinnvandring. Regjeringen ville ha en strategi for å forenkle prosessen med å innvilge oppholdstillatelse for å arbeide, og en skrittvis avvikling av systemet med å kreve en vurdering av tilbudet av arbeidskraft på arbeidsmarkedet:

\footnotetext{
inresa och vistelse i forskningssyfte» tatt inn i Utlänningslagen. Regeringens proposition till Riksdagen, RP $167 / 2007 \mathrm{rd}$

${ }^{42}$ Utlänningslag 30.4.2004/301, 79 §.

${ }^{43}$ Utlänningslag 30.4.2004/301, 81 a § (20.102006/34).

${ }^{44}$ RP 265/2002 rd, s. 7

${ }^{45}$ RP 265/2002 rd, s. 76 f.

${ }^{46}$ RP 265/2002 rd, s. 78 f.

${ }^{47}$ Regeringens invandrarpolitiska program. Statsrådets principbeslut 19.10.2006.
} 
«Projektet anknyter till målet i regeringsprogrammet att stimulera arbetskraftsrelaterad invandring. Bland annat ska tillståndssystemet förenklas (uppehållstillstånd innehåller alltid rätt att utföra förvärvsarbete) samt att man successivt frångår prövning av tillgången på arbetskraft» ${ }^{48}$

De viktigste ankepunktene mot det eksisterende systemet har vært at reglene for å få oppholdstillatelse har vært uklare. Regjeringen hevdet i 2008 at «regleringen av detta uppehållstillstånd är svårtolkad och flertydig». ${ }^{49}$ Samtidig kan det oppstå forsinkelser i behandlingen av søknadene. Til tross for at arbeidskraftkontorene svært sjelden avviste søknader om oppholdstillatelse på grunn av tilgangen på arbeidskraft innenlands, fører denne vurderingen til lengre saksbehandlingstid, mente regjeringen, som ønsket at beskyttelsen av den innenlandske arbeidskraften først og fremst skulle skje gjennom å påse at ansettelsesvilkårene for utenlandsk arbeidskraft var i overensstemmelse med loven. Migrations- och Europaminister Astrid Thors understreket våren 2008 at regjeringens mål var å stimulere arbeidsrelatert innvandring. ${ }^{50}$

Sommeren 2008 ble et forslag til lovendring sendt på høring (remiss). Forslaget gikk ut på å avvikle ordningen med vurdering av tilbudet av arbeidskraft på arbeidsmarkedet, og dermed redusere beslutningsprosessen fra to til ett trinn. Ved en slik ordning kan arbeidsgiver få et større ansvar for å dokumentere at arbeidskraften ikke er tilgjengelig innenfor det europeiske arbeidsmarkedet. En oppholdstillatelse skal gi rett til å arbeide uavhengig av bransje, den skal gis for inntil fem år, og det skal deretter være mulig å søke om permanent oppholdstillatelse. Regjeringen foreslo også å frata bedriftene mulighet for å søke om oppholdstillatelse for arbeidstakere. Bare arbeidstakere selv skulle kunne søke om oppholdstillatelse for å arbeide. ${ }^{51}$

Den økonomiske krisen som satte inn i 2008 fikk regjeringen til å avvente utviklingen. Reformen ble imidlertid forberedt, og i desember 2009 la regjeringen fram forslag til forenkling av systemet for oppholdstillatelser for arbeidstakere. ${ }^{52}$ Forslaget, som er motivert ut fra ønsket om å fremme arbeidsinnvandring, innebærer at arbeidsmarkedsmyndigheten ikke lenger skal foreta en arbeidsmarkedsvurdering. I stedet skal det etableres et system etter svensk modell, der arbeidsgiveren overtar denne funksjonen. Arbeidsgiver skal ha plikt til å dokumentere forsøk på å rekruttere arbeidstakere fra EU/EØS-området før det kan utstedes oppholdstillatelse for arbeidstaker fra tredjeland. ${ }^{53}$ Bortfallet av myndighetenes arbeidsmarkedsvurdering gjør at avgjørelsen om oppholdstillatelse

\footnotetext{
${ }^{48}$ Systemet för uppehållstillstånd för arbetstagare revideras, pressmeddelande den 23 oktober 2007.

${ }^{49}$ Revidering av systemet med uppehållstillstånd för arbetstagare; beslut om att inleda prosjektets andra fas, Inrikesministeriets beslut av den 25. februari 2008.

${ }^{50}$ Projektet för att revidera systemet med uppehållstillstånd för arbetstagare går in i sin andra fas, pressmeddelande från Inrikesministeriet den 3. mars 2008.

${ }^{51}$ Utkastet till regeringspropositionen om revidering av uppehållstillstånd för arbetstagare för utlåtande den 24 juni 2008, pressmeddelande från Inrikesministeriet den 26. juni 2008.

${ }^{52}$ RP 269/2009 rd.

${ }^{53}$ Inrikesministeriet, pressmeddelanden 17.12.2009.
} 
for arbeidstakere reduseres fra to beslutninger til én. Migrationsverket skal alene fatte vedtak. ${ }^{54}$

Hovedregelen etter det nye forslaget er at alle som kommer til Finland i den hensikt å arbeide, skal ha oppholdstillatelse for arbeidstakere. Spesialbestemmelsen som i dag gir spesifiserte grupper, deriblant ledere, spesialister og vitenskapsmenn, rett til å arbeide ubegrenset uten oppholdstillatelse for arbeidstakere, vil falle bort. ${ }^{55}$ Den behøves ikke, fordi det ikke lenger skal foretas noen offentlig arbeidsmarkedsvurdering for noen grupper. Etter det nye lovforslaget får alle som har oppholdstillatelse, uten hensyn til grunnlaget, rett til å arbeide dersom loven ikke sier noe annet. Dette gjør at for eksempel utenlandske studenter vil få samme rett til å arbeide som finske studenter.

For både vedvarende og midlertidig arbeid skal det bevilges oppholdstillatelse for arbeidstakere. Er arbeidet av vedvarende karakter skal det gis en kontinuerlig oppholdstillatelse, første gang på inntil fem år. I henhold til lovforslaget, skal en oppholdstillatelse, i tråd med gjeldende lovgivning, gis for en spesifikk bransje. Er arbeidet uten tvil av midlertidig karakter, for eksempel sesongarbeid, skal det gis en midlertidig (tilfälligt) oppholdstillatelse. Migrationsverket skal vurdere dette. ${ }^{56}$

Den nye lovendringen er ventet å tre i kraft fra 2011.

\subsubsection{Partene i arbeidsmarkedet}

Finland har fem organisasjoner for ingeniører. TEK, Teknikens Akademikerförbund rf., oppgir å ha rundt 70000 medlemmer, og organiserer ingeniører med høyere utdanning (diplomingeniörer). TEK er medlem i sentralorganisasjonen for akademikere, Akava.

TFiF, Tekniska Föreningen i Finland, er en svenskspråklig organisasjon for ingeniører og arkitekter i Finland. TFiF har rundt 4000 medlemmer. Organisasjonene TFiF og TEK samarbeider om tjenestene, og dobbeltmedlemskap er mulig.

DIFF, Driftsingeniörsförbundet i Finland, er en svenskspråklig organisasjon for ingeniører med rundt 3300 medlemmer. DIFF står tilsuttet Akava og har et samarbeid med TFiF om utgivelse av et fagblad.

I tillegg finnes UIL, Uusi Insinööriliitto (Union of Professional Engineers) med over 60000 medlemmer, og KTK, Tekniikan Asiantuntijat, som er en fagforening for kommunale tekniske funksjonærer med litt over 10000 medlemmer. Begge disse foreningene står tilknyttet Akava.

Teknologiateollisuus er arbeidsgiver- og bransjeorganisasjon for teknologiindustrien i Finland. Organisasjonen er medlem av EK, Arbeidsgiverorganisasjonen Finlands Näringsliv Teknologiateollisuus organiserer

\footnotetext{
${ }^{54}$ RP 269/2009 rd, s 16 ff.

${ }^{55} 79$ § er foreslått fjernet i Utlänningslagen. RP 269/2009 rd.

${ }^{56}$ RP 269/2009 rd. s. 17, 25.
} 
virksomheter innenfor elektronikk- og metallindustri, mekanisk engineering og IT-industri, med til sammen 266000 ansatte.

Partene i arbeidslivet møtes jevnlig og har et nært samarbeid med myndighetene om arbeidsinnvandringen. Organisasjonene har ikke selv utformet egne program for rekruttering av utenlandsk arbeidskraft, men har gitt sin støtte til å endre dages system. Økonomisk krise og tegn på økt arbeidsløshet har imidlertid fått partene til å gi uttrykk for et ønske om å gå langsomt fram med reformarbeidet.

Akademikerorganisasjonen Akava ga i 2008 regjeringen sin støtte da organisasjonen uttalte seg om forslaget til lovendring. Akava støttet regjeringens målsetting om å gjøre både innvandring og integrasjon mer effektiv. ${ }^{57}$ Akava advarte imidlertid mot at integrasjonsarbeidet kunne svekkes dersom innvandringen økte, og understreket at kunnskaper i finsk språk var avgjørende for å få til en god integrering. Organisasjonen pekte også på at effektivitet ikke måtte gå på bekostning av rettssikkerheten i avgjørelsene.

Akava ga sin støtte til regjeringens forslag om å reformere forvaltningspraksis, det vil si avvikle praksisen med vurdering av tilbudet av arbeidskraft. Men Akava manet til forsiktighet, og viste til endringene som var nødvendige i den regionale forvaltningen. Akava understreket at de viktigste målene måtte være å arbeide for å integrere utlendinger som allerede var kommet til Finland, og sikre arbeidsvilkårene for utenlandske arbeidstakere gjennom god kontroll, både før og etter at arbeidet i Finland ble påbegynt.

\subsection{Rekruttering og innvandring av ingeniører fra tredjeland}

\subsubsection{Arbeidsinnvandring til Finland fra tredjeland}

Utenlandske arbeidstakere som har søkt om oppholdstillatelse for arbeidstakere i Finland økte markant fra 2006 og fram til 2008. I 2009 er det registrert en nedgang i søknader. Tabell 2 viser antallet innvilgede oppholdstillatelser etter søknadsgrunn. Vi ser at antallet som fikk innvilget oppholdstillatelse for arbeidstakere økte med $100 \%$ fra 2006 til 2008, og utgjorde i 2007 og 2008 over $30 \%$ av de innvilgede søknadene. Det er viktig å være oppmerksom på at de fleste søknadene om oppholdstillatelse i gruppen «annet grunnlag» også omfatter arbeidstakere som har rett til å arbeide i Finland, men som har søkt oppholdstillatelse ut fra et annet søknadsgrunnlag enn opphold for arbeidstakere. Dette kan for eksempel være ansatte innenfor vitenskap eller det kan være ledere og spesialister i private selskaper.

\footnotetext{
${ }^{57}$ Akavan lausunto selvitysmies Norrbackin raportissa esitetyistä maahanmuuttohallinnon ja maahan-
} muuttoviraston toiminnan kehittämistä koskevista ehdotuksista, AKAVA 13.6.2008. 
Tabell 2 Innvilgede oppholdstillatelser i Finland (ekskl. asyl- og flyktningesaker) etter søknadsgrunn og år. Kilde: Migrationverket, Finland.

\begin{tabular}{lrrrr}
\hline & $\mathbf{2 0 0 6}$ & $\mathbf{2 0 0 7}$ & $\mathbf{2 0 0 8}$ & 2009*$^{*}$ \\
\hline Arbeidstillatelse & 2872 & 5280 & 5930 & 2460 \\
Selvstendig næringsdrivende & 58 & 68 & 67 & 42 \\
Finsk opprinnelse & 368 & 374 & 395 & 346 \\
Student & 3196 & 3810 & 4496 & 3332 \\
Annet grunnlag & 2186 & 2710 & 2934 & 1978 \\
Familiebånd & 4107 & 5045 & 5784 & 4149 \\
Totalt & 12787 & 17287 & 19606 & 12307 \\
\hline
\end{tabular}

* Tall for 2009 gjelder perioden 01.01.09-30.09.09.

Søknader om oppholdstillatelse for arbeidstaker har i det alt vesentligste blitt godkjent. I 2007 ble $90 \%$ av søknadene om oppholdstillatelse godkjent, og i 2008 var tallet 86 \%. De fleste avslag ble gitt på grunn av arbeidsbetingelsene. ${ }^{58}$ Tall for 2009 viser imidlertid at andelen avslag er økende. Over $26 \%$ av søknadene har ikke blitt innvilget. ${ }^{59}$ For gruppen «annet grunnlag», som i mange tilfeller omfatter høyt utdannet arbeidskraft, ligger imidlertid avslagsprosenten godt under $10 \%$.

Figur 1 viser tall for de ti største opprinnelsesland når det gjelder søknader om oppholdstillatelse i Finland. I 2008 var Russland og Kina de to viktigste med henholdsvis 5325 og 1752 søknader totalt. Andelen søknader om oppholdstillatelse for å arbeide utgjorde rundt $40 \%$ av disse søknadene. For også å få med gruppen av høyt utdannede arbeidssøkere har vi i analysen inkludert søknader på "annet grunnlag” i tallene for arbeidstillatelser. For søkere fra India, som var det tredje største opphavslandet i 2008, utgjorde $66 \%$ av søknadene forespørsel om oppholdstillatelse for å arbeide. Bare søknadsgruppen fra Ukraina hadde en større andel søknader om arbeidstillatelser. Figur 3 viser at land som India, Ukraina og Thailand er viktige opprinnelsesland for utenlandsk arbeidskraft i Finland. På grunn av antallet søknader er også Russland og Kina viktige opprinnelsesland, selv om mange søknader fra disse landene er begrunnet i andre forhold enn arbeid. For Kinas del er gjelder mange søknader opphold for studenter. Det er også en tidsfaktor som kommer inn og påvirker hvor stor andel søknader fra et land som gjelder arbeidstillatelse. Det er først og fremst nye rekrutteringsland som skårer høyt. Når personer fra et land eller område er etablert i Finland, vil ekteskap og familiegjenforening kunne utgjøre en økende andel av søknadsgrunnlaget fra dette landområdet.

\footnotetext{
58 ”Järjestelmä ei ole vastannut alkuperäistä tarkoitustaan, sillä työvoiman saatavuusharkinnan nojalla hylätään hyvin vähän hakemuksia, monilla ammattialoilla ei käytännössä ollenkaan: v. 2007 työntekijän oleskelulupaa koskevista päätöksistä myönteisiä oli 90 \% ja kielteisiä 10 \%; kielteisistä päätöksistä enemmistö tehtiin työsuhteen ehtojen perusteella.” De viktigaste riktlinjerna för förslaget till reform av systemet för uppehållstillstånd för arbetstagare, Inrikesdepartementet PM 14.3.2008.

${ }^{59}$ Migrationsverket, Finland. Residence permit decisions 1.1.2009-30.9.2009.
} 
口Antall arbeidstillatelser (venstre akse) — Andel arbeidstillatelser (höyre akse)

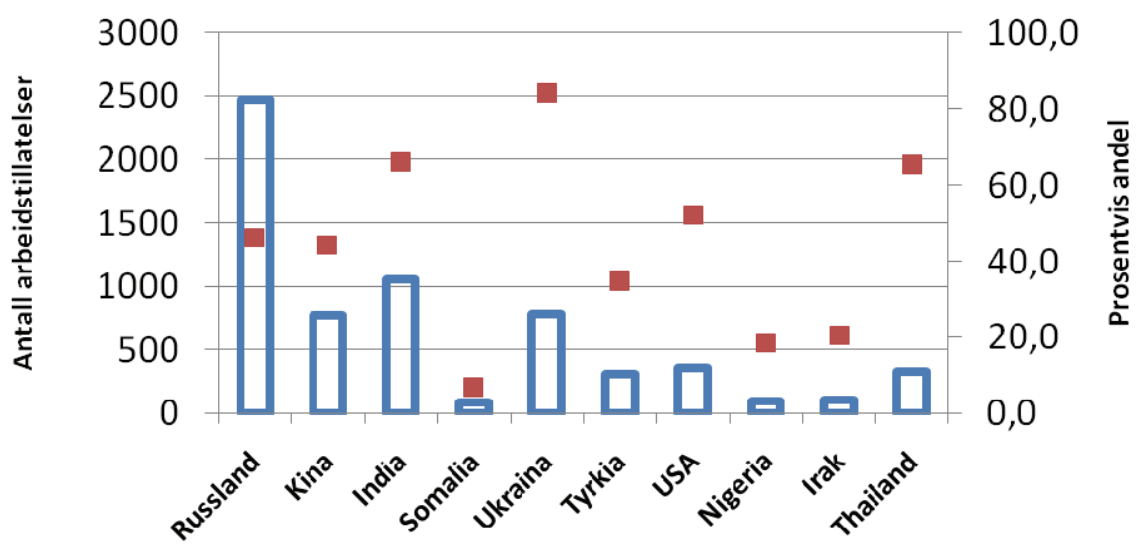

Fordelt på de ti største opprinnelsesland for alle typer grunnlag (ekskl. asyl- og flyktningesaker) rangert etter antall søknader totalt fra venstre mot høyre. Venstre akse (søyle) viser antall arbeidstillatelser (inkludert søknader på «annet grunnlag»). Høyre akse (punkt) viser den prosentvise andelen søknader om arbeidstillatelser av alle typer søknader om oppholdstillatelse.

Kilde: Migrationsverket, Finland

Figur1. Søknader om oppholdstillatelse i 2008 for arbeidstakere inkludert søknader på «annet grunnlag»

\subsubsection{Mobilitet blant ingeniører}

Det finnes lite tilgjengelig statistikk over arbeidsinnvandringen til Finland som gir et bilde av de ulike yrkesgruppene. ${ }^{60}$ Ingeniører som kommer fra tredjeland vil i mange tilfeller ikke bli registrert innenfor gruppen som søker om oppholdstillatelse som arbeidstaker, men vil få oppholdstillatelse på annet grunnlag. Det er derfor vanskelig å si noe sikkert om hvor stor mobilitet det har vært av ingeniører over landegrensene og inn i Finland. Noe statistikk over utenlandske studenter finnes imidlertid på Undervisningsministeriets nettside. ${ }^{61}$

Verken på arbeidstaker- eller arbeidsgiversiden har organisasjonene i Finland inntrykk av at tilstrømningen av ingeniører har vært spesielt stor. Innenfor visse bransjer, som IT og elektronikkindustrien, er det kjent at mange utenlandske ingeniører har hatt arbeidsopphold i Finland. Det er imidlertid usikkert i hvilken grad dette er midlertidig opphold og i hvilken grad det er ingeniører som har flyttet til Finland for å ta fast arbeid.

Ser vi på tallene for hvilke land søkerne av oppholdstillatelse i Finland har kommet fra, finner vi kanskje noen forsøksvise svar på hvor stor gruppen av høyt utdannede er innenfor søkergruppen. Søknader på «annet grunnlag» omfatter som oftest arbeid innenfor særskilte områder, inkludert ledere og spesialister i private selskaper. Det er imidlertid en sam-

\footnotetext{
${ }^{60}$ Se Arbets- och näringsbyrån, http://www.mol.fi/mol/fi/02_tyosuhteet_ja_lait/02_ulkom_suomessa/ 00_luvat/00_osaratkaisut/index.jsp

${ }^{61}$ https://kotaplus.csc.fi/online/Etusivu.do?lng=sv
} 
mensatt gruppe som ikke uten videre kan sies å være høyt utdannede. Gruppen søkere på «annet grunnlag» utgjorde, sammen med søkerne om oppholdstillatelse for arbeidstaker, $35 \%$ av arbeidsinnvandringen fra tredjeland i 2008.

Hvis vi skiller mellom søknader om oppholdstillatelse som arbeidstaker og søknader på "annet grunnlag” finner vi at det i 2008 var 4103 søknader om oppholdstillatelse som arbeidstaker og 2268 søknader på «annet grunnlag». Figur 2 viser hvordan disse fordeler seg på de viktigste opprinnelseslandene.

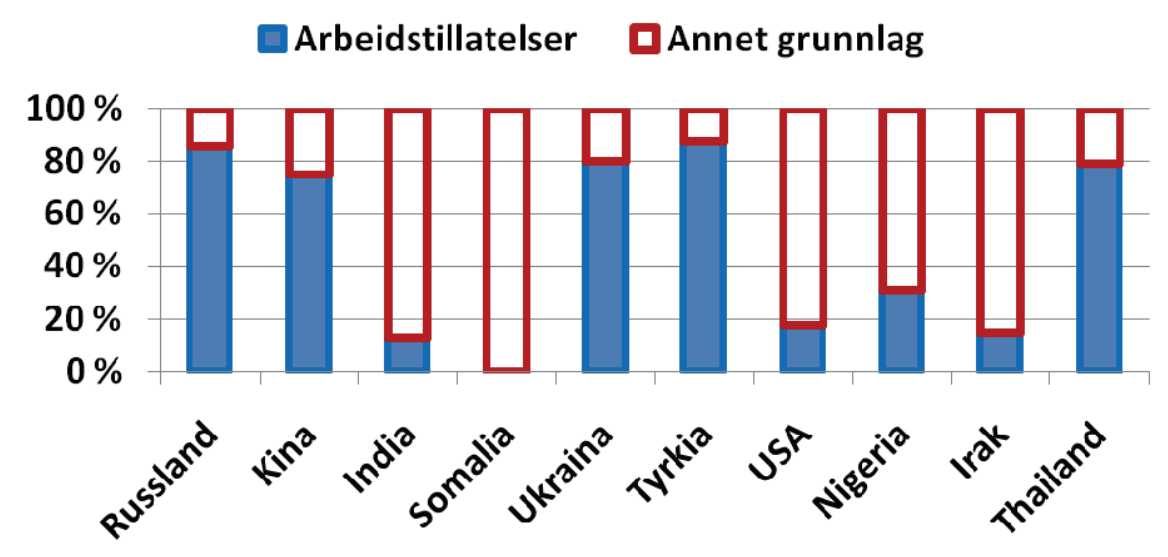

Fordelt på de ti største opprinnelsesland for alle typer grunnlag (ekskl. asyl- og flyktningesaker) rangert etter antall søknader totalt fra venstre mot høyre. Kilde: Migrationsverket, Finland.

Figur 1 Søknader om oppholdstillatelse i 2008 prosentvis fordelt mellom søknader om oppholdstillatelse som arbeidstaker og søknader på «annet grunnlag»

Av figuren ser vi en polarisering: Enten leverer søkere fra landet søknader om oppholdstillatelse som arbeidstaker, eller de leverer en søknad som klassifiseres under «annet grunnlag». Trolig kan utdanningsforskjeller i søkergruppen forklare noe av dette. Vi ser at land som India og USA i det vesentligste har søknader på "annet grunnlag”. ${ }^{62}$ Søkere fra disse landene er trolig i mange tilfeller høyt utdannet, og går inn i virksomheter i Finland som ledere eller spesialister, eller de er engasjert i forskning og utvikling. Mange er trolig ingeniører. På grunn av antallet representerer også søknadene på «annet grunnlag» fra russere og kinesere en betydelig andel av denne gruppen. I 2008 var antallet søknader på «annet grunnlag» fra de fire landene India, USA, Russland og Kina 1762.

Søkere fra Russland, Kina, Ukraina og Tyrkia har hovedsakelig sendt søknader om oppholdstillatelse som arbeidstaker. Dette kan skyldes at de ikke har høyere utdanning og dermed ikke hentes inn av bedrifter som spesialister (utför sakkunniguppdrag som kräver specialkompetens). Arbeidstaker- og arbeidsgiverorganisasjonene peker på at Russland, Kina og Tyrkia er land der industrien i Finland har hentet ufaglært og faglært arbeidskraft.

\footnotetext{
${ }^{62}$ For landene Somalia, Nigeria og Irak, er det trolig andre grunner (asylsökand eller annet) til at deres søknader om arbeidstillatelse havner i kategorien «annet grunnlag».
} 


\subsubsection{Saksbehandlingstid}

Saksbehandlingstiden ved søknader om oppholdstillatelse i Finland kan variere. I mange tilfeller vil det gi liten mening i å se på gjennomsnittstall for å få et bilde av saksbehandlingstiden for en kurant søknad, fordi komplekse eller ufullstendige enkeltsøknader trekker opp gjennomsnittet. Arbeidsgiverne mener at lang saksbehandlingstid i liten grad har berørt ingeniører, men at det tidligere har vært et problem knyttet til søknader om oppholdstillatelse for ufaglærte og faglærte. Ifølge Inrikesministeriet er det i dag få klager på saksbehandlingstiden. ${ }^{63}$ Migrationsverkets statistikk viser at for søknader om oppholdstillatelse som arbeidstaker var saksbehandlingstiden 1,6 måneder i 2008, mens den for de ni første månedene i 2009 var 1,8 måneder (55 dager) ${ }^{64}$ For søknader på "annet grunnlag” var saksbehandlingstiden henholdsvis 1,2 måneder i 2008 og 1,5 måneder (46 dager) de ni første månedene i 2009.

\subsubsection{Rekrutteringspolitikk rettet mot høyt utdannet arbeidskraft}

Selv om arbeidsmarkedet for ingeniører i Finland under høykonjunkturen var så stramt at det ikke ble foretatt noen arbeidsmarkedsvurdering av arbeidssøkere fra tredjeland, har ansettelsen av høyt utdannet arbeidskraft fra land utenfor EU/EØS-området vært begrenset. EURES- representantene ved arbets- och närigsbyrån er først og fremst opptatt av arbeidsformidling fra EU/EØS-land, men kontoret i Helsinki har en avdeling orientert mot arbeidssøkere fra tredjeland. Både ingeniørorganisasjonene TEK og TFiF, og arbeidsgiverorganisasjonen Teknologiateollisuus, legger i dag stor vekt på utdanningens og forskningens betydning for å sikre en god og stabil tilgang på høyt utdannet arbeidskraft. Ingeniørorganisasjonene ser kvaliteten på utdanningen som en nøkkel til å lykkes. Organisasjonene mener dagens finansieringssystem for høyere utdanning stimulerer til å øke antall studenter framfor å heve kvaliteten på studiene. De går heller inn for å redusere antallet studenter og satse mer på de beste.

Teknologiateollisuus understreker betydningen av et nært samarbeid mellom industrien og universitetene. Finsk industri har investert betydelige midler i forskning og utdanning, ikke minst i et pilotprosjekt rettet mot det nye Alto-universitetet i Helsinki. ${ }^{65}$ Her har også arbeidstakerorganisasjonene bidratt, og ingeniørorganisasjonen TEK har vedtatt å bevilge en million euro til stiftelsen bak Alto-universitetet. ${ }^{66}$ En ny universitetslov gir større frihet for universitetene til å disponere sine resurser. Arbeidsgiverorganisasjonen håper dette skal bidra til å bygge bro over det skillet som har vært mellom universitetene og industrien. Det vil være av betyd-

\footnotetext{
${ }^{63}$ Intervjuer 02.10.09 og 20.10.2009.

${ }^{64}$ Migrationsverket. Hakemusten keskimääräiset käsittelyajat maahanmuuttovirastossa, 2008, 2009.

${ }^{65}$ Alto University er dannet ved en sammenslåing av Helsinki School of Economics, University of Art and Design Helsinki og Helsinki University of Technology.

${ }^{66}$ http://www.tek.fi/index.php?id=1692\#paragraph5
} 
ning for den framtidige kompetansebyggingen i Finland. Organisasjonen peker også på at det er bekymringsfullt at antallet finske studenter som reiser utenlands for å studere har gått ned.

Under arbeidet med å reformere lovverket og forvaltningen knyttet til arbeidsinnvandring, har de finske myndighetene forberedt flere reformer. I tillegg til det framlagte forslaget om å forenkle systemet for søknad om oppholdstillatelser, finnes det derfor planer for hvordan ulike deler av forvaltningen kan bidra til å realisere regjeringens politikk for å fremme arbeidsinnvandring når Finland måtte få behov for dette. Disse planene bygger på at arbeidsinnvandring skal være et supplement til det innenlandske arbeidsmarkedet, og fremme et multikulturelt arbeidsliv som følger etiske standarder. Eksempel på tiltak som er tatt med i planarbeidet er:

- Arbets- och näringsbyråene, som ikke lenger skal foreta en arbeidsmarkedsvurdering av søknader, får et utvidet ansvar for å sikre tilgangen på arbeidskraft lokalt.

- Social- och hälsovårdministeriet skal utrede hvordan rekruttering av helsepersonell best kan foregå slik at det tas hensyn til kompetanse og språkkunnskaper.

- Inrikesministeriet skal engasjere en kontaktperson for migrasjonsspørsmål som skal arbeide ved de finske utenriksstasjonene og bistå i arbeidet med å rekruttere utenlandsk arbeidskraft. Kina og India er aktuelle rekrutteringsland.

- Undervisningsministeriet og universitetene skal samarbeide med andre etater for å øke informasjonen om utdanningsmuligheter og studier i Finland.

- Det skal legges til rette for en bedre organisert språkopplæring for arbeidsinnvandrere til Finland.

Rekrutteringsstrategien til finske myndigheter er først og fremst rettet mot det indre markedet i Europa, men dersom finske virksomheter og forvaltning har bruk for særskilt kompetanse, kan det være nødvendig å søke etter dette også utenfor Europa.

\subsubsection{Arbeidsledighet og framtidig behov for ingeniørkompetanse}

Ved utgangen av 2008 lå den månedlige arbeidsledigheten i Finland på litt over $6 \%{ }^{67}$ Ingeniører med utdanning fra polytekniske høyskoler hadde en arbeidsledighetsrate på 3,4 \%, mens sivilingeniører og arkitekter samlet hadde en arbeidsledighet på 2 \%. I november 2009 var ledigheten for disse gruppene økt til henholdsvis 4,8 og 2,9\%. I tillegg var $3 \%$ av

\footnotetext{
${ }^{67}$ Statistics Finland, Labour Forse Statistics, Monthly analysis of unemployment rates by sex I 1995XII 2008
} 
ingeniørene (inkl. arkitekter) permittert. ${ }^{68}$ Den økonomiske krisen viser dermed en markant forverret situasjon for ingeniører i Finland.

I et mer langsiktig perspektiv er myndighetene og partene i arbeidslivet opptatt av at Finland også i framtiden har en god tilgang på ingeniører. Ingeniørorganisasjonene viser til at det utdannes mange ingeniører i Finland, og at tilgangen på ingeniører har vært god. Partene er enig i at det er viktig å øke kvaliteten på utdanningen, og stimulere til utvikling og forskning. Myndighetene ønsker å legge til rette for at utenlandsk arbeidskraft skal være lett tilgjengelig for finske virksomheter, men understreker at det er etterspørselen som kommer til å styre innvandringstakten.

\subsection{Nasjonale utfordringer i arbeidsinnvandringspolitikken}

\subsubsection{Regulering}

Finland vedtok en ny utlendingslov i 2004. Etter dette har det vært foretatt enkelte endringer for å tilpasse regelverket bestemmelsene i EU. I 2007 igangsatte regjeringen et utredningsarbeid blant annet med sikte på å forenkle saksgangen ved søknader om arbeidsinnvandring. Dette arbeidet har resultert i ulike forslag til endringer av forvaltningspraksis og tiltak for å fremme arbeidsinnvandring.

Regelverket som gjelder innvandring fra tredjeland stiller opp et generelt krav om at det skal foreligge tilbud om arbeid. Det stilles også et krav til arbeidsmarkedsvurdering. Denne utføres enten individuelt eller gjennom å stille opp regionale lister over yrker og bransjer som har mangel på arbeidskraft. Finland har ingen kompetansekrav knyttet til bestemmelsene om oppholdstillatelse for arbeidstakere. Høyt utdannet arbeidskraft som har tilbud om arbeid får i mange tilfeller oppholdstillatelse med hjemmel i en bestemmelse om ledere i virksomheter og spesialistoppdrag. Her foretas det ingen arbeidsmarkedsvurdering.

Regjeringen la i desember 2009 fram forslag om å forenkle saksbehandlingen ved søknader om oppholdstillatelse for arbeidstaker og avvikle ordningen med arbeidsmarkedsvurdering. Med den nye ordningen vil arbeidsgiver få et større ansvar for å dokumentere at arbeidskraften ikke er tilgjengelig innenfor det europeiske arbeidsmarkedet før det kan ansettes arbeidstakere fra tredjeland.

\subsubsection{Strategier}

Lov- og regelverk som gjelder oppholds- og arbeidstillatelser i Finland har i alt vesentlig vært etterspørselsstyrt, som i Norge. Arbeidsgiver har søkt etter kandidater og valgt ut dem som er blitt tilbudt jobb i Finland. Da den nye utlendingsloven ble vedtatt i 2004, ønsket myndighetene å

\footnotetext{
${ }^{68}$ Statistikk fra TEK, basert på data fra Arbets- og näringsministeriet.
} 
skape en enklere og mer transparent saksbehandling. I dag foreligger det forslag til endringer i loven av 2004 som går videre i retning av å forenkle saksbehandlingen og overføre ansvaret for arbeidsmarkedsvurderingen til arbeidsgiverne. Arbeidsgiverorganisasjonene har tidligere gitt uttrykk for at praksisen med offentlig arbeidsmarkedsvurdering har vært for tidkrevende og har hatt svært liten betydning. Partene i arbeidslivet er i dag enige om at det eksisterende systemet bør endres, men arbeidstakerorganisasjonene har advart mot å gjennomføre endringene for raskt, og har lagt vekt på viktigheten av å sikre god kontroll med arbeidsforholdene.

I likhet med Norge har også Finland vedtatt ordninger som gjør det lettere for utenlandske studenter som ønsker å søke arbeid i Finland etter endt utdanning, å bli i landet. Det har ikke vært fremmet forslag fra myndighetene eller partene på arbeidsmarkedet om å utforme andre ordninger for tilbudsdrevet innvandring, som for eksempel Blue Card-ordninger.

Verken myndighetene eller ingeniørorganisasjonene har drøftet særskilte tiltak for å stimulere innvandring av ingeniører. Ingeniørorganisasjonene har understreket at integrering og språkopplæring er av vesentlig betydning for å få arbeidsinnvandrere til å bli værende og fungere i det finske samfunnet.

\subsubsection{Realiteter}

Det har vært en økende arbeidsinnvandring til Finland gjennom høykonjunkturen fram til 2008, men innvandringen fra tredjeland har vært relativt beskjeden. Utenlandske arbeidstakere med høyere utdanning har i mange tilfeller fått oppholdstillatelse i Finland på «annet grunnlag». Samlet sett omfattet arbeidsinnvandringen fra tredjeland 6371 personer i 2008, hvorav 35 \% fikk oppholdstillatelse på "annet grunnlag”.

Det finnes ikke tilgjengelig statistikk i Finland over innvandringen for ingeniører eller andre yrkesgrupper. Ingeniørorganisasjonen har ikke noen oversikt over utenlandske ingeniører i Finland.

På samme måte som for de andre landene i Norden er språk en viktig faktor som hemmer rekruttering av ingeniører fra utlandet. Finland har også et generelt lavt lønnsnivå for ingeniører, som kan medvirke til å gjøre landet noe mindre attraktivt. Det som trolig har hatt stor betydning for internasjonaliseringen i finsk arbeidsliv de siste årene, er Nokias profil og gjenkjennelsesverdi i utlandet. Svært mange av de utenlandske arbeidstakerne med høyere utdanning i Finland jobber i Nokia. Nokia er også en så stor og internasjonal virksomhet at det interne arbeidsmarkedet i Nokia er en viktig faktor som rekrutterer utenlandske ingeniører til Finland. 


\section{Kilder og referanser}

Kvalitative intervjuer og samtaler er gjennomfört med:

Lars Engström, Verksamhetsledare, DI, Tekniska Föreningen i Finland

Marjo Hirvonen, Adviser, The Finnish Association of Graduate Engineers TEK

Mervi Karikorpi, Director, Science and Education Policy, The Federation of Finnish Technology Industries Ari Sipilä, Deputy Director, Labour Market, The Federation of Finnish Technology Industries

Arja Saarto, Planning Officer, Inrikesministeriet

Tuomi Kurri, Director, Inrikesministeriet

\section{Referanser:}

Flere dokumenter knyttet til «Reform av systemet för uppehållstillstånd för arbetstagare i Finland» finnes på Inrikesministeriets nettside: http://www.intermin.fi /intermin/home.nsf/pages/FBA05E8106E D33F4C22573F500324768

Statistikk over migrasjon til Finland, Migrasjonsverket, http://www.migri. fi/netcomm/default.asp 


\section{Island}

Nana Wesley Hansen og Anne Marie Boesen

Forkortelser

- EØS - Det Europæiske Økonomiske Samarbejdsområde

- $S I$ - Islandsk Industri

- $S V$ - Foreningen for Statsautoriserede Ingeniører i Island

- TFI - Forbundet for Højskoleingeniører

- VFI - Forbundet for Civilingeniører

\subsection{National lovregulering af arbejdsindvandring fra tredjelande}

\subsubsection{Regelvœerk for arbejdsindvandring fra tredjelande}

For at få arbejdstilladelse i Island skal man have opnået opholdstilladelse hos Det Islandske Direktorat for Immigration. Ansøgning om opholds- og arbejdstilladelse sendes samtidigt til henholdsvis Det Islandske Direktorat for Immigration og Arbejdsdirektoratet. I tilfælde af afslag kan sagen ankes til Social- og Forskningsministeriet. Ansøgningsproceduren afviger alt efter, hvilken kategori arbejdstageren tilhører. For alle typer kategorier gælder det, at arbejdstageren skal betale en afgift for ansøgningen, og denne vil ikke blive behandlet, før myndighederne har modtaget betaling. I 2009 kostede det ca. 335 danske kroner, at få behandlet sin ansøgning

Arbejdstagere fra redjelande kan få opholdstilladelse, hvis 1) der er midlertidig mangel på arbejdskraft inden for en sektor, 2) vedkommende er særligt kvalificeret, og 3) personen er sportsudøver. De to første typer af opholdstilladelse er af særlig interesse for denne rapport. ${ }^{69}$

Det er kun muligt at opnå opholdstilladelse via kategorien midlertidig mangel på arbejdskraft, hvis der ikke er tilgængelig arbejdskraft inden for Islands grænser eller indenfor EU/EØS, Schweiz og Færøerne. Ansøgeren skal desuden have en underskrevet jobkontrakt, og arbejdsgiveren skal underskrive ansøgningen om opholdstilladelse. Ansøgningen skal godkendes, før arbejdstageren må ankomme til Island. Arbejdstagere, der får opholdstilladelse på baggrund af midlertidig mangel på arbejdskraft,

\footnotetext{
${ }^{69}$ Lov No. 96/2002
} 
har begrænsede muligheder for at blive længere tid i landet. Tilladelse kan som udgangspunkt kun blive forlænget én gang og op til et år. Der er dog mulighed for udvidelse, hvis der er tale om et klart afgrænset projekt. Er opholdstilladelsen udløbet, skal den udenlandske borger opholde sig to år i udlandet, før personen kan ansøge om ny opholdstilladelse. Det er ikke muligt for udenlandske borgere, som har fået ophold via denne kategori, at søge om familiesammenføring. Endvidere har den midlertidige opholdstilladelse ikke indflydelse på en senere ansøgning om permanent opholds- og arbejdstilladelse.

For at opnå opholdstilladelse som arbejdstager med scerlig kompetence skal ansøgerens arbejdsgiver kunne dokumentere, at ansøgerens særlige egenskaber er nødvendige for arbejdspladsen. Som eksempel på kvalificerende uddannelse kan nævnes håndværk, kunst, teknisk eller universitetsuddannelse, som er anerkendte i Island. Dokumentation for uddannelsesmæssige forudsætninger skal derfor også vedlægges ansøgningen. Som udgangspunkt er opholdstilladelse af et års varighed, men vedkommende kan søge om forlængelse i op til to år. Den kvalificerede arbejdstager kan søge om familiesammenføring gældende for arbejdsperioden og har mulighed for at søge om forlængelse af sit ophold i Island. De indledende opholdstilladelser har indflydelse på en senere ansøgning om permanent opholdstilladelse. Efter 4 år kan der søges om bosættelsesret og permanent arbejdstilladelse.

Ifølge loven for udenlandske borgeres ret til at arbejde ${ }^{70}$ kan Arbejdsdirektoratet udstede arbejdstilladelse til arbejdstageren på baggrund af opnået opholdstilladelse. ${ }^{71}$ I 2002 indførte Island ny lovgivning gældende for arbejdstilladelse for udenlandsk arbejdskraft, ${ }^{72}$ hvilket også inkluderede arbejdstagere fra tredjelande. Loven blev udvidet i 2008, hvorefter arbejdstagere kan få arbejdstilladelse efter følgende 7 grupper:

1. Hvis arbejdet kræver særlig kompetence

2. Hvis der er et temporært behov for arbejdskraft

3. Hvis der er et temporært behov for idrætsfolk

4. Hvis der er et temporært behov for arbejdskraft på grund af særlige forhold

5. Arbejdstilladelse på grund af familieforening

6. Arbejdstilladelse for studerende eller au-pair

7. Arbejdstilladelse på basis af service-kontrakter

Det helt grundlæggende princip for arbejdstilladelse er, at arbejdskraften ikke kan findes indenfor Islands egen arbejdsstyrke eller EØS. I den forbindelse høres også den relevante fagforening. En tidsbegrænset arbejdstilladelse gives til arbejdstageren under forudsætning af en konkret job-

\footnotetext{
${ }^{70}$ Lov nr. 97/2002

${ }^{71}$ Arbejdstilladelse udstedes i overensstemmelse med Regulativ om udenlandsk arbejdskrafts ret til arbejde (nr. 339/2005).

${ }^{72}$ Lov nr. 97/2002
} 
kontrakt, og at arbejdsgiver sikrer den nødvendige sundhedsforsikring og hjemsendelse, hvis lønmodtageren bliver uarbejdsdygtig. I særlige tilfælde kan en specialist-arbejdstilladelse udstedes til en udenlandsk arbejdstager, som sendes til Island for at udføre en specifik opgave indenfor maksimalt 6 måneder, og som er tilknyttet en virksomhed, der ikke har en islandsk afdeling. Det forudsættes, at der er en service-kontrakt med en virksomhed i Island. Der kan også udstedes opholds- og arbejdstilladelse til studerende, som læser ved en anerkendt islandsk uddannelsesinstitution eller i forbindelse med en au-pair-ansættelse. Permanent arbejdstilladelse er knyttet til udstedelse af permanent opholdstilladelse.

Enkelte grupper er undtaget fra at skulle søge om opholds- og arbejdstilladelse, hvis deres ophold er på under 4 uger inden for et år. Det gælder blandt andet videnskabelige medarbejdere, kunstnere, sportstrænere, journalister, repræsentanter på korte virksomhedsbesøg, ansatte konsulenter og instruktører, som arbejder med specialiseret konstruktionsarbejde, montering, kontrol og reparation. Sidstnævnte gælder primært, hvis udstyret er underlagt garantier vedrørende reparation og lignende, som kræver specialiseret arbejde.

\subsubsection{Udviklingen i regelvcerket og rekrutteringsinitiativer for højtkvalificeret arbejdskraft}

Det grundlæggende princip for rekruttering af arbejdskraft til Island er at sikre konstant ligevægt mellem jobsøgere i Island og ledige job på arbejdsmarkedet. Under arbejdsløshedsperioder er det kun tilladt at udstede arbejdstilladelser, såfremt ingen kvalificeret jobsøger kan findes i Island eller inden for EØS/EU. Man ønsker på den måde at prioritere islændinge og EØS-borgere, som den arbejdskraft, der primært skal rekrutteres. Baggrunden for ændringer i lovgivningen for udenlandsk arbejdskraft i 2008, hvor nye typer arbejdstilladelser blev indført, var en ekstraordinær stor efterspørgsel efter arbejdskraft til en række stillinger som følge af det store opsving i den islandske økonomi frem til dette tidspunkt.

Opsvinget toppede i 2007 og skyldtes først og fremmest en række store halvoffentlige og private anlægsinvesteringer i kraftværker og aluminiumsværker, et stort privatforbrug samt en meget høj byggeaktivitet. Island har igennem flere årtier været et land med efterspørgsel på arbejdskraft, men det økonomiske opsving medførte en yderligere tiltrækning af arbejdskraft. Det nye udbud af arbejdskraft og tjenesteydelser på det islandske arbejdsmarked fra særligt de nye EU-medlemslande skabte en vis bekymring for forringelser af løn og arbejdsvilkår. Fra 2006 tog man derfor tiltag til at øge registrering og kontrol af særligt EUtjenesteydere i Island. ${ }^{73}$

I foråret 2008 slog den internationale finanskrise imidlertid igennem i Island med blandt andet en svækkelse af den islandske krone på over 50 \%.

\footnotetext{
${ }^{73}$ Dølvik \& Eldring 2008
} 
Den stærkt forringede økonomiske situation førte til hurtige stigninger i en ellers lav arbejdsløshed. Endvidere har man kunnet registrere, at en del af den udenlandske arbejdskraft er rejst fra Island. På den baggrund vurderer det islandske Arbejdsdirektorat, at det gældende regelværk ${ }^{74}$ er tilstrækkeligt, og at der ikke er brug for fremtidige ændringer.

\subsubsection{EU's rolle i regulering af arbejdsindvandring fra tredjelande}

Island er ikke medlem af EU, men er en del af Det Europæiske Økonomiske Samarbejdsområde (EØS), og som sådan indgår Island i EURESsamarbejdet, som dog primært fokuserer på formidling af arbejdskraft internt mellem EU/EØS-landene. I 2008 blev medlemskab af EU igen diskuteret i Island, og Island har 23. juli 2009 afsendt ansøgning om EUmedlemskab. Egentlige optagelsesforhandlinger er endnu ikke indledt, men ansøgningen er blevet behandlet i løbet af 2009.

\subsubsection{Parterne på arbejdsmarkedet og rekrutteringsstrategier}

I Island er $85 \%$ af alle lønmodtagere organiserede i fagforeninger, og også arbejdsgiverorganisationerne er stærke. Godt $90 \%$ af den økonomiske aktivitet i industrien vurderes således at være repræsenteret i industriens føderale arbejdsgiverorganisation (SI). Arbejdsmarkedets parter bidrager til lovgivningen via høringer, og ved ny lovgivning på særligt arbejdsmarkedsområdet er der tradition for samråd mellem regering og parter.

Under det økonomiske opsving argumenterede både arbejdsgiverne i industrien (SI) og fagforeningerne for, at administrationen omkring arbejdstilladelser til kvalificeret udenlandsk arbejdskraft udenfor EØS/EUområdet skulle forbedres. Der har således ikke været krav om egentlige liberaliseringer af lovgivningen, men sagsbehandlingen har været kritiseret for at være for tung. Særligt for arbejdsgiverne har det været vigtigt, at virksomhederne får smidig adgang til den nødvendige arbejdskraft, og de har i den forbindelse også været noget kritiske over for den indflydelse, fagforeningerne har på beslutningen om at angive opholdstilladelse.

Island har flere ingeniørforeninger. Foreningen for Statsautoriserede Ingeniører i Island (SV) arbejder med rådgivning i forhold til ansættelse og opsigelse. Både SV, forbundet for civilingeniører (VFI) og forbundet for højskoleingeniører (TFI) beskæftiger sig samtidig med bredere faglige spørgsmål. Alle tre organisationer deler kontor og arbejder tæt sammen. Der er ikke sket en egentlig holdningsændring hos ingeniørforeningerne i forhold til tiltrækningen af udenlandsk arbejdskraft. Afgørende for organisationerne er det at sikre, at de udenlandske arbejdstagere får samme løn og arbejdsvilkår som de islandske arbejdstagere med tilsvarende stillinger og kvalifikationer. Fagforeningerne spiller en central rolle i sikrin-

\footnotetext{
${ }^{74}$ Dette gælder primært Lov 97/2002
} 
gen af dette. Uanset typen af udenlandsk arbejdstager skal den relevante fagforening således høres, hver gang der skal udstedes en arbejdstilladelse. Således tjekker de eksamensdokumentation i forhold til kvalificeret arbejdskraft. I forhold til midlertidig arbejdskraft kommenterer de endvidere på, hvorvidt der egentlig er ledighed inden for området. Alle tre ingeniørforeninger tilbyder særlige gæstemedlemskaber til udenlandske arbejdstagere fra søsterorganisationerne i de nordiske lande, men ikke til arbejdstagere uden for disse lande.

\subsection{Rekruttering og indvandring af ingeniører i tal}

\subsubsection{Mobilitet i tal}

I nedenstående diagram 1 er antallet af ingeniører fra tredjelande, som har fået arbejdstilladelse eller fået forlænget eller fornyet sin arbejdstilladelse i Island, angivet i årene fra 2005-2008. Det er tydeligt, at det største antal tilladelser blev givet i 2007, hvor det økonomiske opsving, som tidligere nævnt, var på sit højeste.

Tabel 3 over antallet af arbejdstilladelser udstedt til ingeniører ${ }^{75}$

\begin{tabular}{lcccc}
\hline Årstal & 2005 & 2006 & 2007 & 2008 \\
\hline Antal arbejdstilladelser til ingeniører & 39 & 75 & 125 & 53 \\
\hline
\end{tabular}

Der er ikke på noget tidspunkt taget særlige rekrutteringsinitiativer i forhold til ingeniører i Island, hverken fra myndighedernes side eller arbejdsmarkedsorganisationernes. Under opsvinget har der været fokus på sikring af løn og arbejdsvilkår og smidiggørelse af sagsbehandling ved rekrutteringen af udenlandsk arbejdskraft, men dette har ikke haft særligt fokus på ingeniører.

Det skal nævnes, at de islandske ingeniørforeninger til tider har svært ved at gennemskue, om de udenlandske ansøgere rent faktisk besidder en ingeniøruddannelse. Det er derfor muligt, at tallene også rummer grupper af fx. it-specialister, som ikke nødvendigvis har, hvad der i Island svarer til en ingeniøruddannelse bag sig.

Helt generelt står det klart, at langt færre udenlandske arbejdstagere ankommer til Island i 2009 end de forudgående år. Samtidig er en del af den udenlandske arbejdskraft taget hjem igen, siden krisen har gjort sit indtog i den islandske økonomi. Dette er illustreret i tabel 4, der viser den generelle migration til og fra Island. Langt hovedparten af den eksterne migration består af borgere fra Polen, Danmark, Norge og Sverige.

\footnotetext{
${ }^{75}$ Tal fra Arbejdsdirektoratet, Island, marts 2009
} 
Tabel 4 over antal immigranter/emigranter til/fra Island ${ }^{76}$

\begin{tabular}{lrrrrr}
\hline Årstal & $\mathbf{2 0 0 5}$ & $\mathbf{2 0 0 6}$ & $\mathbf{2 0 0 7}$ & $\mathbf{2 0 0 8}$ & Jan-jun2009 \\
\hline Immigranter & 4.680 & 7.070 & 12.528 & 7.471 & 1.589 \\
Emigranter & 938 & 1.535 & 4.019 & 5.850 & 2.350 \\
\hline
\end{tabular}

\subsubsection{Fremtidigt behov for ingeniørkompetence}

Det islandske arbejdsmarked har i årtier været karakteriseret ved en stærk efterspørgsel efter arbejdskraft. I de seneste år frem til 2008 har der under opsvinget i Island været mangel på ingeniører, hvilket ifølge arbejdsmarkedsorganisationerne blandt andet skyldes at finansbranchen har tiltrukket en stor mængde ingeniører. Under opsvinget er lønningerne i denne branche steget mærkbart og har således gjort branchen særlig attraktiv. Den finansielle krise har imidlertid ramt Island hårdt, hvorfor den generelle arbejdsløshed har været stigende siden foråret 2008. Ledigheden var i september 2008 på 1,3 \%, mens den i april 2009 var på 9,1 \%. Selv når der er taget højde for de nye job, der skabes, forventes det yderligere, at op imod 10.000 arbejdspladser vil forsvinde inden for de næste 2-3 år. 5-6.000 af disse job vil forsvinde inden for byggeindustrien, der har været meget stærkt overophedet, og det vil have stor betydning for ingeniører og jobmulighederne for udenlandske arbejdstagere. Også ingeniørforeningerne forventer at ledigheden vil stige, dog mener de, at der forsat vil være enkelte brancher med efterspørgsel på arbejdskraft, særligt indenfor innovation. Ledighedsprocenten for højskoleingeniører har i løbet af 2009 ligget mellem 4,5-5 \%, mens den har været noget højere for civilingeniører ${ }^{77}$. Imidlertid forventer ingeniørforeningerne at ledigheden i faget generelt vil aftage efter et par år. Arbejdsdirektoratet vurderer ligeledes at efterspørgslen efter ingeniører på kort sigt er negativ, mens den på længere sigt vil være moderat.

\subsection{Nationale udfordringer i rekrutteringspolitikken}

\subsubsection{Regulering}

Islandsk lovgivning har flere forskellige typer af opholdstilladelser for tredjelandsborgere, som kan danne baggrund for arbejdstilladelse. Arbejdstagere kan få ophold, hvis 1) der er midlertidig mangel på arbejdskraft inden for en sektor, 2) vedkommende er særligt kvalificeret, og 3) personen er sportsudøver. De to førstnævnte ordninger, som er af relevans for rekruttering af ingeniører fra tredjelande, forudsætter, at der er

\footnotetext{
${ }^{76}$ Statistics Iceland, Migration, External Migration 2005-2009, last updated 2009.08.21

${ }^{77}$ For civilingeniører har ledighedsprocenten varieret mellem 5,2-6,7 \% i 2009. Tal for perioden januar 2008 til november 2009 fra det islandske Arbejdsdirektorat og fra Forbundet for Civilingenioørernes (SV) og Forbundet for Højskoleingeniørernes (TFí) medlemsregistre.
} 
tale om konkrete jobtilbud, og at der enten er mangel på lige netop denne type arbejdskraft, eller at man har særlige kompetencer, som er nødvendige for den pågældende arbejdsplads. Den førstnævnte ordning er mere restriktiv i forhold til at kunne få sin familie med til Island og kunne forlænge opholdet, mens ordningen for særlig kvalificeret arbejdskraft gør det muligt at medbringe familie og nemmere at forlænge arbejdsopholdet i Island. Arbejdstilladelse udstedes på baggrund af opholdstilladelse til arbejdstager og regler for arbejdstilladelse. Arbejdsdirektoratet kan udstede midlertidig arbejdstilladelse, hvor fagforeningerne skal høres eller den særlige specialist-arbejdstilladelse, som kræver, at der er en servicekontrakt med en virksomhed i Island.

Der har ikke været stillet krav om ændringer i forhold til det nuværende regelværk. Imidlertid mener særligt arbejdsgiverne at sagsbehandlingstiden i forhold til ansøgninger om opholds- og arbejdstilladelser kan forbedres.

\subsubsection{Strategier}

Island har igennem årtier været kendetegnet som et land med en stor efterspørgsel efter arbejdskraft set i forhold til egen arbejdsstyrke. Det økonomiske opsving frem til 2008 har særligt øget tiltrækningen af udenlandsk arbejdskraft, dog primært fra andre europæiske lande. Det grundlæggende princip for strategier i forhold til rekruttering af arbejdskraft i Island er at opnå ligevægt på arbejdsmarkedet ved at skabe balance mellem jobsøgere i Island og ledige job på arbejdsmarkedet. Man ønsker således at prioritere islændinge og EØS-borgere som den arbejdskraft, der primært skal rekrutteres.

Der har ikke været særligt fokus på at udvikle strategier målrettet lige præcis ingeniører, da arbejdskraftsmanglen under det økonomiske opsving i Island har været bredt fordelt på mange jobtyper. Ved revisionen af lovgivningen for arbejdstilladelse i 2008 er der dog blevet lagt entydig vægt på at lave en særordning for særligt kvalificerede arbejdstagere.

De islandske fagforeninger har generelt lagt stor vægt på at forbedre informationsniveauet om det islandske arbejdsmarked blandt den udenlandske arbejdskraft og forebygge og bekæmpe forringelser af løn og arbejdsvilkår.

\subsubsection{Realiteter}

Island blev hårdt ramt af den globale finansielle krise, hvilket har haft stor indflydelse på beskæftigelsessituationen og også kan ses i de generelle migrationstal. Arbejdsløsheden er steget fra omkring $1 \%$ før krisen til omkring 9 \% i midten af 2009. Island modtager langt færre udenlandske arbejdstagere og blandt de, der allerede er i landet, tager en stor del derfra igen. Dette afspejler sig også i antallet af arbejdstilladelser til ingeniører 
fra tredjelande. I øjeblikket er ledigheden blandt ingeniører også stigende. Selvom enkelte firmaer vil efterspørge særlige kompetencer, er det først på længere sigt, at behovet for ingeniører vil stige igen.

\section{Kilder og referencer}

Kilder:

Skriftlige kvalitative spørgsmålsbesvarelser og enkelte supplerende telefoninterviews er gennemført med:

Arbejdsdirektoratet, Island

Foreningen for Statsautoriserede Ingeniører i Island (SV)

Islandsk Industri (SI)

Referencer:

Act on Foreigners No. 96/2002

Dølvik, Jon Erik \& Line Eldring (2008): Arbeidsmobilitet fra de nye EU-landene til Norden - Utviklingstrekk og konsekvenser, Nordisk Ministerråd, 2008:502.

Foreign Nationals' Right to Work Act, No. 97/2002, with subsequent amendments
Icelandic Confederation of Labour (ASI), Work in Iceland Booklet Regulation on Foreign Nationals' Right to Work Act, No. 339/2005

Statistics Iceland, Migration, External Migration 2005-2009, last updated 2009.08.21 www.statice.is

SVAPU (Teknikföretagen, Teknologi Industrin, Norsk Industri, Dansk Industri (DI), Islandsk Industri (SI)) (2006) Nordic labour markets and foreign workers - a joint review.

The Icelandic Confederation of Labour (ASI) and the Confederation of Icelandic Employers (SA), March 2004, Agreement on Foreigners in the Icelandic Labour Market 


\title{
5. Norge
}

\author{
Åsmund Arup Seip
}

\section{Forkortelser}

- Tekna - Teknisk naturvitenskapelig forening

- NITO - Norsk Ingeniør- og Teknikerorganisasjon

- $N H O$ - Norges Hovedorganisasjon (arbeidsgiver- og bransjeorganisasjoner)

- Norsk Industri - Bransje/arbeidsgiverorganisasjon tilknyttet NHO

- OLF - Oljeindustriens Landsforening, tilknyttet NHO

- St.meld. - Stortingsmelding

- Ot.prp. - Odeltingsproposisjon (lovforslag)

- UDI - Utlendingsdirektoratet

- NAVO/Spekter - Arbeidsgiverorganisasjon, ikke tilknyttet NHO

- $N A V$ - Arbeids- og velferdsetaten

\subsection{Nasjonale lovreguleringer av arbeidsinnvandring fra tredjeland}

\subsubsection{Dagens regelverk for arbeidsinnvandring fra tredjeland}

Den 15. mai 2008 vedtok Stortinget i Norge en ny utlendingslov. En ny forskrift til loven, utlendingsforskriften, ble vedtatt i oktober 2009. ${ }^{78}$ Det nye regelverket vil tre i kraft 1 . januar 2010. ${ }^{79}$

Den nye utlendingsloven omfatter både innvandring av humanitære grunner, inkludert asylsøkere og familiegjenforeninger, og innvandring som følge av arbeids- eller studieopphold. Loven er en fullmaktslov som gir regjeringen mulighet til å styre innvandringspolitikken gjennom utforming av forskrifter. Utlendingsforskriften er dermed en viktig del av regelverket.

Utlendingslovens § 23 trekker opp de alminnelige innvandringsregulerende vilkår for å få oppholdstillatelse i Norge for arbeidstakere fra land utenfor EU/EØS-området. Det stilles krav om at søkeren er tilbudt arbeid

\footnotetext{
${ }^{78}$ Lov av 15. mai $2008 \mathrm{nr}$. 35 om utlendingers adgang til riket og deres opphold her (utlendingsloven), og Forskrift om utlendingers adgang til riket og deres opphold her (utlendingsforskriften), 15.10.09 (nr. 1286).

${ }^{79}$ Regelverket som gjelder fram til 1. januar 2010 er Utlendingsloven av 24. juni 1988 nr. 64 og

Utlendingsforskrift av 21. desember 1990.
} 
og at tilbudet som hovedregel skal gjelde heltidsarbeid for én arbeidsgiver. Det er også et generelt krav til at lønns- og arbeidsvilkår ikke skal være dårligere enn etter gjeldende tariffavtale, regulativ eller det som ellers er normalt for vedkommende sted og yrke. ${ }^{80}$ Utenlandske arbeidssøkere skal ikke fortrenge innenlandsk arbeidskraft eller arbeidskraft fra EU/EØS-området, og det skal derfor som hovedregel foretas en arbeidsmarkedsvurdering for hver enkelt søknad. ${ }^{81}$

Utlendingsforskriften gir utfyllende regler om grunnlaget for oppholdstillatelse for arbeidstakere fra tredjeland. Den skiller mellom følgende grunnlag: 1) oppholdstillatelse til faglærte mv., 2) oppholdstillatelse til spesialister, 3) oppholdstillatelse for inntil seks måneder for sesongbasert virksomhet, og 4) oppholdstillatelse til ufaglærte russiske arbeidstakere mv., 5) oppholdstillatelse til russiske grensependlere, 6) oppholdstillatelse til sjøfolk, og 7) gruppetillatelser for arbeidsgivere for arbeid av tidsbegrenset varighet for faglærte arbeidstakere. ${ }^{82}$ Det er særlig de to første grunnlagene som vil ha betydning for innvandring av høyt kvalifiserte arbeidstakere som vil arbeide i landet ut over konkrete enkeltoppdrag. Arbeids- og inkluderingsdepartementet fastsetter en kvote for personer som kan søke opphold på disse grunnlagene.

Bestemmelsen om oppholdstillatelse til faglcerte er en videreføring av spesialistbestemmelsen og stiller krav om arbeidssøkerens kompetanse. ${ }^{83}$ Kompetansen, som skal være relevant for stillingen, kan være fagutdanning eller tilsvarende realkompetanse, utdanning fra universitet eller annen høyere utdanningsinstitusjon. Forskriften åpner også for å gi tillatelse til personer som ikke har formell fagutdanning, men som har spesielle kvalifikasjoner, det vil si personer som har tilegnet seg kvalifikasjoner på et slikt nivå gjennom praksis, eller ved å kombinere teori og praksis. ${ }^{84}$ Når særlige hensyn tilsier det, kan det kreves fagutdanning ut over nivå for videregående skole. ${ }^{85}$ Oppholdstillatelse til faglærte kan fornyes og danner grunnlag for permanent oppholdstillatelse. Permanent oppholdstillatelse gir utlendingen rett til å bo og arbeide i Norge uten tidsbegrensning.

Bestemmelsen om oppholdstillatelse til spesialister er basert på at arbeidstaker ansettes som spesialist med et lønnstilbud som ligger over en angitt terskel på 500000 kroner årlig (cirka EUR 60 000). ${ }^{86}$ Dette er en bestemmelse som i mange tilfeller vil komme til anvendelse for ingeniørgrupper. Det stilles særskilte krav om at arbeidsgiver skal oppfylle vilkå-

\footnotetext{
${ }^{80}$ Utlendingsloven $\S 23$.

${ }^{81}$ Ot.prp. nr. 75 (2006-2007), s. 168.

${ }^{82}$ Forskrift om utlendingers adgang til riket og deres opphold her (utlendingsforskriften), 15.10.09 (nr. 1286), § 6.

${ }^{83}$ Forslag til ny utlendingsforskrift av 30.01.09, kapittel 6 - Opphold i forbindelse med arbeid studier $m v$. ., § 6-1.

${ }^{84}$ Høringsnotat av 30.01 .09 om Utleningsforskriftens kapittel 6 - Opphold i forbindelse med arbeid studier $m v$.

${ }^{85}$ Dette har blant annet blitt gjort overfor «nasjonalitetskokker» og religiøse lærere og ledere. NOU 2004:20 Ny utlendingslov, s. 186 note 5.

${ }^{86}$ Forskrift om utlendingers adgang til riket og deres opphold her (utlendingsforskriften), 15.10.09 (nr. 1286), § 6-2. Oppholdstillatelse til spesialister.
} 
rene i regelverket om offentlige anskaffelser. Det vil si at arbeidsgiver kan legge fram skatteattest for betalt merverdiavgift og skatt, og en egenerklæring om å overholde de norske lovbestemte kravene til helse, miljø og sikkerhet (HMS). Oppholdstillatelse til spesialister kan fornyes og danner grunnlag for permanent oppholdstillatelse.

Både i tidligere og nytt regelverk vil fagutdannede og spesialister være omfattet av en kvote. For at arbeidsinnvandring ikke skal fortrenge innenlandsk arbeidskraft, fastsetter forskriften et krav om at stillingen som skal besettes av en arbeidstaker fra tredjeland, ikke kan besettes ved innenlandsk arbeidskraft eller arbeidskraft fra EU/EØS-området. Dette er et krav om arbeidsmarkedsvurdering som foregår ved at stillingen en viss tid utlyses gjennom den offentlige arbeidsformidlingen i Norge og det europeiske EURES-nettverket. ${ }^{87}$ For å oppnå en enklere og raskere saksbehandling vil Arbeids- og inkluderingsdepartementet, i samråd med Nærings- og handelsdepartementet og Finansdepartementet, fastsette en årlig kvote tillatelser som kan gis faglærte og spesialister uten at det foreligger en konkret arbeidsmarkedsvurdering. ${ }^{88}$ Kvoten som tidligere gjaldt faglærte og spesialister var på 5000 tillatelser. Denne kvoten har hittil ikke blitt oppfylt, og det gjennomføres derfor i praksis svært få arbeidsmarkedsvurderinger. ${ }^{89}$

Det nye regelverket inneholder enkelte andre bestemmelser som er utformet for å gjøre det lettere for høyt kvalifisert arbeidskraft å få arbeide i Norge. Utlendingsforskriften har en bestemmelse om tidlig arbeidsstart. Arbeidsgivere som fyller vilkårene i regelverket om offentlige anskaffelser vil få adgang til å la arbeidstakere som er faglærte eller spesialister få starte arbeidet før en oppholdstillatelse foreligger. Arbeidsgiveren har da ansvaret for at arbeidstakerne fyller vilkårene for tillatelsen. ${ }^{90}$

I 2007 fikk utenlandsstudenter i Norge en generell tillatelse til å arbeide deltid (20 timer per uke) og i ferier under studieopphold i Norge. ${ }^{91}$ Denne bestemmelsen videreføres i det nye regelverket, som også åpner for at utenlandske studenter som har kompetanse som faglært, eller har gjennomført fagutdanning eller høyere utdanning i Norge, kan få oppholdstillatelse i inntil seks måneder for å søke arbeid. ${ }^{92}$ Disse bestemmelsene kan lette inntreden på arbeidsmarkedet for utenlandske studenter som studerer i Norge. Forskriften har også fått en bestemmelse som skal gjøre det lettere for utenlandske arbeidssøkere å lære seg norsk språk eller skaffe seg nødvendig tilleggsutdanning for å få godkjent sin fagutdanning i Norge, før de søker arbeid. ${ }^{93}$

\footnotetext{
${ }^{87}$ NOU 2004:20 viser (i note 6 side 186) til rundskriv for Aetat.

${ }^{88}$ Forskrift om utlendingers adgang til riket og deres opphold her (utlendingsforskriften), 15.10.09 (nr. 1286), § 6-12.

${ }^{89}$ NOU 2004:20 s. 186.

${ }^{90}$ Forskrift om utlendingers adgang til riket og deres opphold her (utlendingsforskriften), 15.10.09 (nr. 1286), § 6-8.

${ }^{91}$ Arbeids- og inkluderingsdepartementet, rundskriv nr. 24/2007, 23. mai 2007.

${ }^{92}$ Forskrift om utlendingers adgang til riket og deres opphold her (utlendingsforskriften), 15.10.09 (nr. 1286), § 6-29.

${ }_{93}$ Forskrift om utlendingers adgang til riket og deres opphold her (utlendingsforskriften), 15.10.09 (nr. 1286), § 6-19.
} 
Den nye forskriften utvider ordningen med visum for arbeidssøkere som er faglærte. Faglærte skal kunne gis oppholdstillatelse i seks måneder, mot tidligere tre måneder, for å søke arbeid som faglært. ${ }^{94}$

Søknader om arbeidstillatelse som fremmes fra Norge skal sendes det lokale politiet som behandler søknaden. Søknader fra utlandet skal sendes til en norsk utenriksstasjon, og behandles der eller i Utlendingsdirektoratet (UDI).

\subsubsection{Internasjonale forpliktelser og forholdet til EUs regelverk}

I den nye utlendingsloven er det presisert at kontrollen med inn- og utreise og utlendingers opphold i riket skal skje også i samsvar med internasjonale forpliktelser. ${ }^{95}$ Det er særlig Flyktningkonvensjonen ${ }^{96}$, Den europeiske menneskerettskonvensjonen ${ }^{97}$ og FNs konvensjon om barns rettigheter ${ }^{98}$ som får anvendelse innenfor asylpolitikken. Med grunnlag $\mathrm{i}$ Amsterdamtraktaten som trådte i kraft i 1999, har EU utviklet et system av rettsakter som regulerer det felleseuropeiske asylsystem (Common European Asylum System). Av disse aktene er Norge bare bundet av Dublin II-forordningen og den såkalte Eurodac-forordningen, som begge har som formål å regulere hvilket land som skal behandle en eventuell asylsøknad, og håndheve dette regelverket. ${ }^{99}$

Når det gjelder arbeidsinnvandring er det opp til hvert enkelt land selv å fastsette vilkårene for innvandringen fra tredjeland. EU har i direktiv av 25. november 2003 regulert retten til permanent oppholdstillatelse i EUlandene for tredjelandsborgere som har vært bosatt i EU over lang tid. ${ }^{100}$ Dette direktivet gjelder ikke for Norge. EUs direktiv 2004/38/EF om fri bevegelighet for unionsborgere og deres familiemedlemmer blir gjennomført i norsk rett gjennom den nye utlendingsloven. Det er opprettet en registreringsordning for borgere fra EU/EØS-området, og de vil kunne få varig oppholdsrett etter fem år. ${ }^{101}$

\footnotetext{
${ }^{94}$ Forskrift om utlendingers adgang til riket og deres opphold her (utlendingsforskriften), 15.10.09 (nr. 1286), § 6-30.

${ }^{95}$ Lov av 15. mai 2008 nr. 35 om utlendingers adgang til riket og deres opphold her (utlendingsloven), § 1 .

${ }^{96}$ FNs konvensjon om flyktningers rettslige stilling av 28. juli 1951.

${ }^{97}$ EMK art. 3 om vern mot tortur, umenneskelig eller nedverdigende behandling, og EMK art. 8 om respekt for privatliv og familieliv.

${ }^{98}$ Barnekonvensjonen art. 3, som fastsetter at hensynet til barnets beste skal være et grunnleggende hensyn ved handlinger som berører barn.

${ }^{99}$ St.prp. nr. 38 (2000-2001) Om samtykke til inngåelse av en avtale mellom Kongeriket Norge og Republikken Island og Det europeiske fellesskap om kriterier og mekanismer for å avgjøre hvilken stat som er ansvarlig for behandlingen av en asylsøknad som fremlegges i Norge, Island eller en medlemsstat, kap. 4.1 og 4.2.

${ }^{100}$ Rådets direktiv 2003/109/EF af 25. november 2003 om tredjelandsstatsborgeres status som fastboende udlænding.

${ }^{101}$ Utlendingsloven, kap. 13
} 


\subsubsection{Endringer av regelverket}

Regjeringen la fram forslag til ny utlendingslov i juni 2007. Under arbeidet med utformingen av utlendingsforskriften, la Arbeids- og inkluderingsdepartementet fram en stortingsmelding om arbeidsinnvandring. ${ }^{102}$ Departementet gjennomførte også en høringsrunde over et forlag til ny utlendingsforskrift. Her har en rekke organisasjoner og institusjoner levert høringsuttalelse med synspunkter og endringsforslag.

Endringene i utlendingsloven og i utlendingsforskriften ble blant annet begrunnet med et behov for å forenkle loven. ${ }^{103}$ Den nye utlendingsloven opererer med bare én type tillatelse, oppholdstillatelse. Skillet mellom oppholdstillatelse og arbeidstillatelse er fjernet, og den som får innvilget oppholdstillatelse får automatisk rett til å søke arbeid dersom ikke annet er uttrykkelig fastsatt.

For det andre er flere av hovedbestemmelsene som tidligere sto i forskriften flyttet over i selve loven. Dette gjelder bestemmelsene som skal beskytte innenlandsk arbeidskraft mot konkurranse. Loven krever nå at utenlandske arbeidstakere fra tredjeland skal ha lønn etter gjeldende tariffavtale eller lønnsregulativ for bransjen og at søkeren skal omfattes av en fastsatt kvote, eller at stillingen ikke kan besettes ved innenlandsk arbeidskraft eller arbeidskraft fra EU/EØS-området. Arbeidet skal som hovedregel være heltidsarbeid hos én arbeidsgiver. Disse bestemmelsene lå tidligere i forskriften. Departementet begrunner forslaget om å føre viktige hovedprinsipper ut av utlendingsforskriften og inn i loven med å vise til utredningsarbeidet ${ }^{104}$ og understreke at Stortinget skal fastlegge hovedprinsippene gjennom en ordinær lovgivningsprosess, og at det ikke skal oppstå tvil om at Stortinget har innflytelsen over innvandringsreguleringen. ${ }^{105}$ Begrunnelsen for å fastsette de konkrete vilkårene for innvandring $i$ en forskrift og ikke i loven, er at «behovet for arbeidskraft kan endre seg raskt både med hensyn til art og omfang.» ${ }^{106}$

For det tredje er koblingen mellom tillatelse til å arbeide og selve arbeidsstedet blitt fjernet når det gjelder faglærte. I den gamle utlendingsforskriften var tillatelsen til å arbeide knyttet til «et bestemt arbeid og et bestemt arbeidssted». ${ }^{107}$ I den nye forskriften vil oppholdstillatelse for faglærte bare begrenses til «en bestemt type arbeid». ${ }^{108}$ Dette vil ifølge departementet innebære en utvidelse av retten til å skifte arbeidsgiver, og styrke arbeidsinnvandreres stilling når det gjelder lønns- og arbeidsvil-

\footnotetext{
${ }^{102}$ St.meld. nr. 18 (2007-2008) Arbeidsinnvandring.

${ }^{103}$ Ot.prp. nr. 75 (2006-2007) Om lov om utlendingers adgang til riket og deres opphold her (utlendingsloven), s. 48.

${ }^{104}$ NOU 2004:20.

${ }^{105}$ Ot.prp. nr. 75 (2006-2007), s. 7.

${ }^{106}$ Ot.prp. nr. 75 (2006-2007), s. 169.

${ }^{107}$ Forskrift av 21. desember 1990 om utlendingers adgang til riket og deres opphold her (utlendingsforskriften), § 2.

${ }^{108}$ Forskrift om utlendingers adgang til riket og deres opphold her (utlendingsforskriften), 15.10.09 (nr. 1286), § 6-1. Oppholdstillatelse til faglcerte $m v$.
} 
kår. ${ }^{109}$ Oppholdstillatelse for spesialister vil fremdeles være knyttet til en bestemt arbeidsgiver. ${ }^{110}$

Aldersgrensen for å kunne søke om oppholdstillatelse for å arbeide er endret fra 15 til 18 år. ${ }^{111}$

Når det gjelder søknader fra tredjelandsborgere om oppholdstillatelse for å yte tjenester som utsendt arbeidstaker eller selvstendig oppdragstaker, fastsetter den nye loven et krav om arbeidsmarkedsprøving for ikke å fortrenge innenlandsk arbeidskraft og arbeidskraft fra EU/EØS-området. Utlendingsforskriften gjør imidlertid unntak fra en slik individuell arbeidsmarkedsprøving for gruppetillatelser. ${ }^{112}$ Et vilkår for tillatelse etter disse bestemmelsene er imidlertid at utlendingen er fagutdannet. For øvrig gjelder de samme regler som for individuelle arbeidstakere.

De fleste partiene på Stortinget sluttet seg til regjeringens synspunkter da forslaget til ny lov ble lagt fram. Det var stor enighet om at arbeidsinnvandringen skulle være regulert og behovsstyrt, og ikke fortrenge innenlandsk arbeidskraft. ${ }^{113}$ Fremskrittspartiet markerte som eneste parti en mer restriktiv holdning til det å gi oppholdstillatelser som kan danne grunnlag for permanent oppholdstillatelse. Partiet mente at «tjenesteimport der utenlandske firma påtar seg arbeid i Norge kan være et alternativ til arbeidsinnvandring». ${ }^{114}$ De borgerlige partiene uttrykte frykt for at Norge skulle «tape den internasjonale konkurransen om kvalifisert arbeidskraft» ${ }^{115}$, og representantene fra Høyre, Kristelig Folkeparti og Venstre fremmet følgende forslag som skulle gjøre det lettere å rekruttere kvalifisert arbeidskraft fra tredjeland: ${ }^{116}$ :

- Etablering av flerreisevisum for å sikre fleksibilitet for de som jobber både i Norge og i utlandet innenfor internasjonale bedrifter.

- Etablering av et hurtigspor gjennom forhåndsgodkjenning av bedrifter, slik at faglærte/spesialister kan begynne å arbeide der mens søknad om opphold behandles.

- Fjerne byråkrati ved å la bedriftene i større grad avgjøre om en arbeidstaker har den rette kompetansen som kvalifiserer til å komme inn under ordningen for faglærte/spesialister.

- Be regjeringen vurdere et visumsystem basert på poeng ut fra språk, arbeidserfaring og utdanning, etter modell fra Canada. ${ }^{117}$

\footnotetext{
${ }^{109}$ Ot.prp. nr. 75 (2006-2007), s. 169.

${ }^{110}$ Forskrift om utlendingers adgang til riket og deres opphold her (utlendingsforskriften), 15.10.09 (nr. 1286), § 6-2. Oppholdstillatelse til spesialister.

${ }^{111}$ Denne endringen er ikke begrunnet av departementet i odelstingsproposisjonen. Ot.prp. nr. 75 (2006-2007), s. 111.

${ }^{112}$ Forskrift om utlendingers adgang til riket og deres opphold her (utlendingsforskriften), 15.10 .09 (nr. 1286), § 6-7. Gruppetillatelse til arbeidsgivere.

${ }^{113}$ Komiteens flertall (Arbeiderpartiet, Høyre, SV, Kristelig Folkeparti, Senterpartiet og Venstre). Innst. O. nr. 42 (2007-2008), s. 112.

${ }^{114}$ Merknader fra Fremskrittspartiet, Innst. O. nr. 42 (2007-2008), s. 31.

${ }^{115}$ Merknad fra Frp, Høyre, KrF og Venstre, Innst. O. nr. 42 (2007-2008), s. 31

${ }^{116}$ Merknad fra Høyre, KrF og Venstre, Innst. O. nr. 42 (2007-2008), s. 32.

${ }^{117}$ Forslaget var bare støttet av Kristelig Folkeparti og Venstre. Innst. O. nr. 42 (2007-2008), s. 33.
} 
Disse forslagene er ikke vedtatt av Stortinget. De er uttrykk for den politiske opposisjonens syn på de enkelte spørsmålene knyttet til arbeidsinnvandring.

Parallelt med utarbeidingen av en ny utlendingslov har regjeringen arbeidet særskilt med spørsmålet om arbeidsinnvandring. Regjeringen la fram sin politikk på dette området i en melding til Stortinget i 2008. ${ }^{118} \mathrm{I}$ denne meldingen la regjeringen fram ulike forslag til endringer av regelverket og av administrasjonen av arbeidsinnvandringen. Flere av disse er tatt opp i arbeidet med ny utlendingsforskrift.

Regjeringen ønsket å begrense antall arbeidstakergrupper i regelverket. Høyt kvalifiserte spesialister og faglærte skulle utgjøre to grupper, i tillegg kan tillatelse blant annet gis til sesongarbeidere og ufaglærte russiske borgere og russiske grensependlere. ${ }^{119}$ Regjeringen foreslo å definere spesialistgruppen ut fra et lønnstilbud, mens faglærte fortsatt skulle defineres ut fra utdanningsnivå på nivå med norsk videregående skole. I tillegg fremmet regjeringen i stortingsmeldingen forslag om å bedre informasjonen, og opprette flere servicekontorer for utenlandske jobbsøkere med representanter fra de mest berørte myndighetene. Målet var å redusere saksbehandlingstiden til fire uker når elektronisk saksbehandling var etablert. ${ }^{120}$

I januar 2009 ble forslag til nye forskriftsbestemmelser til lovens kapittel 6, om oppholdstillatelse i forbindelse med arbeid og studier, sendt ut på høring med frist 30. april 2009. I høringen fikk partene i arbeidslivet anledning til å gi uttrykk for sine synspunkter.

\subsubsection{Partene i arbeidsmarkedet}

Både lovforslaget og forslaget til ny utlendingsforskrift ble sendt ut til høring hos organisasjonene i arbeidslivet. LO og NHO støttet i sine uttalelser om loven at vilkårene for innvandring i hovedsak utformes gjennom forskrift. LO uttalte at regelverket måtte ha «Norges behov for arbeidskraft som utgangspunkt.» ${ }^{121} \mathrm{NHO}$ presiserte i sin høringsuttalelse at endringer i regelverket om arbeidsinnvandring må skje i samspill med partene i arbeidslivet. ${ }^{122}$

Både LO og NHO støttet forslaget om å knytte oppholdstillatelsen til «en bestemt type arbeid», og ikke en konkret arbeidsgiver, da lovforslaget var ute på høring. LO mente da at dette ville styrke utlendingens stilling ved å gjøre det mulig å skifte arbeidsgiver. ${ }^{123} \mathrm{LO}$ endret imidlertid oppfatning på dette punktet da forskriftene ble lagt fram. Da mente organisasjonen at det kunne bli vanskelig å sikre at lønns- og arbeidsforhold

\footnotetext{
${ }^{118}$ St.meld. nr. 18 (2007-2008) Arbeidsinnvandring.

${ }^{119}$. Forskrift om utlendingers adgang til riket og deres opphold her (utlendingsforskriften), 15.10.09 (nr. 1286), §§ 6-4, 6-5.

${ }^{120}$ St.meld. nr. 18 (2007-2008), s. 23.

${ }^{121}$ LOs høringsuttalelse til NOU 2004:20, cit. Ot.prp. nr. 75 (2006-2007), s. 169.

${ }^{122}$ NHOs høringsuttalelse til NOU 2004:20, gjengitt i Ot.prp. nr. 75 (2006-2007), s. 169.

${ }^{123}$ LOs og NHOs høringsuttalelse til NOU 2004:20, gjengitt i Ot.prp. nr. 75 (2006-2007), s. 169.
} 
var i overensstemmelse med loven, dersom en arbeidstaker skulle kunne bytte jobb ubegrenset innenfor oppholdstillatelsens varighet. LO var derfor kritisk til regelen, og ba om at det ble bevilget ressurser til kontroll av arbeidstakernes lønns- og arbeidsforhold. LO ville også at myndighetene vurderte et solidaransvar for lønn, der oppdragsgivere var pålagt ansvar for å påse at lovens forpliktelser ble oppfylt av underleverandører som benyttet utenlandsk arbeidskraft. ${ }^{124}$

I høringsuttalelsene til ny utlendingslov er det enighet mellom partene i arbeidslivet om at utenlandsk arbeidskraft skal ha normale lønns- og arbeidsvilkår. Arbeidsgiverorganisasjonen NAVO, nå Spekter, reiste imidlertid spørsmålet om hvorvidt lønn etter «gjeldende tariffavtale» eller «det som er normalt» lønnsnivå for vedkommende sted og yrke var egnede mål for å påse at gjeldende lønnsnivå ble fulgt. NAVO mente det var partene (og arbeidsretten) som tolket avtalene, og at myndighetene ikke kunne ta stilling til innholdet i en tariffavtale. ${ }^{125}$ Departementet mente imidlertid at erfaringer viste at det fungerte hensiktsmessig å ta utgangspunkt i tariffavtaler ved fastsetting av et normalt lønnsnivå, og viste til at myndighetene kunne kontakte partene i arbeidslivet dersom det oppstår tvil om hvordan avtalen skal forstås. ${ }^{126}$

NHO uttalte at de ikke hadde noen innvendinger mot kravet om at utenlandske arbeidstakere skal ha gjeldende lønns- og arbeidsvilkår. NHO påpekte imidlertid at det måtte være det «reelle» lønnsnivået som ble lagt til grunn, og at dette kunne veksle i ulike bransjer og i ulike deler av landet. I tillegg framholdt NHO at det måtte være de samlede lønnsog arbeidsvilkårene som måtte vurderes, ikke bare lønnsnivået. ${ }^{127}$

Partene i arbeidslivet var også i hovedsak positivt innstilt til Arbeidsog inkluderingsdepartementets forslag til utforming av forskrifter. Arbeidstakerorganisasjonene NITO og Tekna og arbeidsgiverorganisasjonen NHO mente alle at en årslønn på 500000 kroner var et riktig nivå for dem som skal defineres som spesialister. ${ }^{128}$ NHO understreket at det måtte vinnes erfaring etter hvert, mens arbeidsgiverorganisasjonen Spekter mente nivået lå noe høyt i forhold til nyutdannet personell. ${ }^{129}$

Alle organisasjonene som har gitt uttalelse om utlendingsloven eller forskriftene har i hovedsak vært positive. Uttalelsene viser at arbeidsmarkedets parter ønsker å påvirke reguleringen og håndteringen av arbeidsinnvandringen fra tredjeland.

NHO uttalte at regelendringer på området måtte skje i «samspill» med partene i arbeidslivet, og uttrykte på den måten at arbeidslivspartene hadde et politisk «eierskap» til interessefeltet.

\footnotetext{
${ }^{124}$ LOs høringsuttalelse til ny utlendingsforskrift, 20.04.09, Høring (2009).

${ }^{125}$ NAVOs høringsuttalelse til NOU 2004:20, cit. Ot.prp. nr. 75 (2006-2007), s. 170.

${ }^{126}$ Ot.prp. nr. 75 (2006-2007), s. 174.

${ }^{127}$ NHOs høringsuttalelse til NOU 2004:20, gjengitt i Ot.prp. nr. 75 (2006-2007), s. 171.

${ }^{128}$ Høringsuttalelser fra NITO, Akademikerne/Tekna, NHO og Spekter til ny utlendingsforskrift, Høring (2009).

${ }^{129}$ Høringsuttalelse fra Spekter til ny utlendingsforskrift, 24.04.2009, Høring (2009).
} 
Alle arbeidsmarkedspartene la til grunn et behovsperspektiv i synet på arbeidsinnvandring. Det var «Norges» (LO) behov for arbeidskraft, eller "virksomhetenes" (NHO) behov som ifølge organisasjonene skulle være utgangspunktet for reguleringen av arbeidsinnvandringen fra tredjeland. NITO og Tekna støttet dette perspektivet, og understreket at organisasjonene mente det var viktig å sikre grunnlaget for en industri med et høyt utviklet kompetansemiljø innenfor teknologifag. ${ }^{130}$

LO har i sine uttalelser særskilt oppmerksomhet på forhold som kan svekke arbeidstakernes lønns- og arbeidsvilkår. Organisasjonen legger dermed stor vekt på konkurranseperspektivet mellom utenlandsk og innenlandsk arbeidskraft. Det er to måter utenlandsk arbeidskraft kan skape en vesentlig konkurranse på. Den ene måten er ved volum. Stor tilgang på utenlandsk arbeidskraft over tid kan legge et press på det innenlandske lønnsnivået slik at dette ikke stiger. Den andre måten er pris. Lønnsnivået holdes nede når utenlandsk arbeidskraft tilbys billigere enn innenlandsk. Kvoteordningen og bestemmelsene i loven som skal sikre at utenlandsk arbeidskraft ikke skal fortrenge den innenlandske, inkludert arbeidskraft fra EU-land, hindrer konkurranse ved volum. For LO var det derfor viktig at loven heller ikke åpnet for konkurranse fra billigere arbeidskraft.

NHOs syn på arbeidsinnvandring, slik det framgår av uttalelsene, er først og fremst at arbeidsinnvandring skal brukes for å dekke virksomhetenes midlertidige behov for arbeidskraft. Arbeidsinnvandring er ifølge NHO «lite egnet til å løse langsiktige utfordringer» knyttet til befolkningsendringer, men viktig for bedrifter som trenger «spesialkompetanse eller har midlertidige behov for arbeidskraft.» ${ }^{131}$ NHO legger dermed til grunn at arbeidskraften som kommer fra tredjeland for en stor del vil være midlertidig, og først og fremst dekke behovet for særskilt spesialkompetanse eller midlertidige behov framkalt av konjunktursvingninger. NHO mener det er viktig å skille mellom innvandring som følge av arbeidskraftbehov og innvandring som følge av internasjonale forpliktelser eller humanitære grunner. ${ }^{132}$

\subsection{Rekruttering og innvandring av ingeniører fra tredjeland}

\subsubsection{Arbeidsinnvandring til Norge fra tredjeland}

Arbeidsinnvandringen til Norge fra tredjeland har økt jevnt de siste årene. Ser vi bort fra de landene som i dag inngår i EU/EØS-området, har antallet arbeidstillatelser utstedt til borgere fra tredjeland steget fra rundt 2800

\footnotetext{
${ }^{130}$ Intervjuer.

${ }^{131}$ NHOs høringsuttalelse til ny utlendingsforskrift, 28.04.09, Høring (2009).

${ }^{132}$ NHOs høringsuttalelse til ny utlendingsforskrift, 28.04.09, Høring (2009).
} 
i år 2000 til over 12300 i 2008. ${ }^{133}$ De fleste av disse arbeidstillatelsene er imidlertid ikke gitt med hjemmel i bestemmelsen for faglærte/spesialister, men kan føres tilbake til andre hjemler i lovverket, som for eksempel familiegjenforening.

Ser vi på endringene i antallet arbeidstillatelser gitt på bakgrunn av bestemmelsen om faglærte/spesialister, ser vi at disse bare representerer en liten andel av alle innvilgede arbeidstillatelser. Figur 3 viser at antallet faglærte/spesialister som fikk førstegangs arbeidstillatelse lå i underkant av 1000 for de fleste årene fra 1999 til 2006, da vi fikk en markant økning. I 2008 var det 3384 personer som fikk innvilget førstegangs arbeidstillatelse som faglært/spesialist.

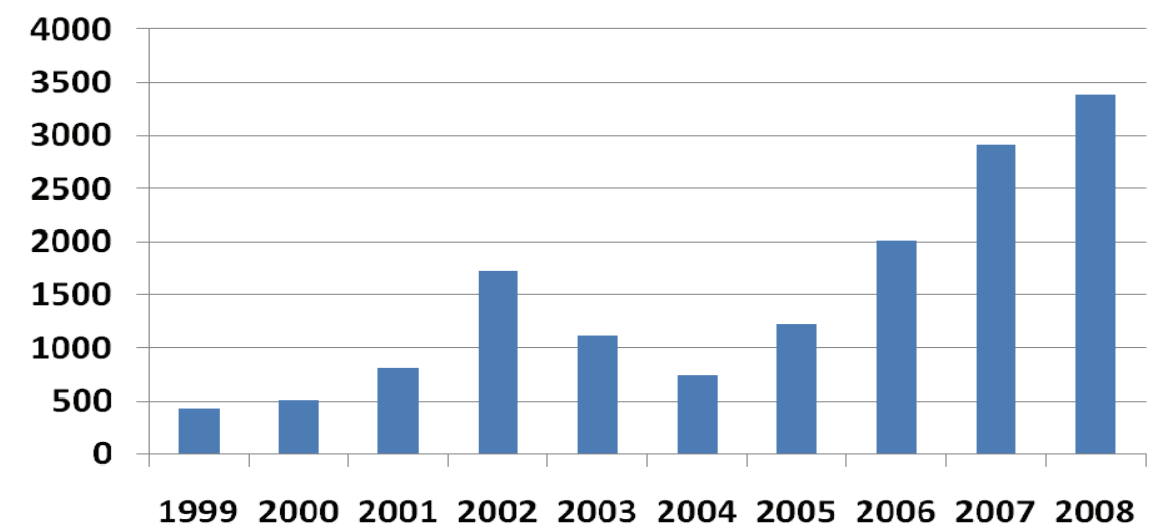

Figur 2 Antall førstegangs arbeidstillatelser som faglcert/spesialist fordelt etter år. Kilde UDI

Det viktigste tredjeland som faglærte/spesialister ble rekruttert til Norge fra i 2008, var India. Figur 4 viser at det deretter følger et knippe land som hver representerer rundt 300 arbeidstillatelser.

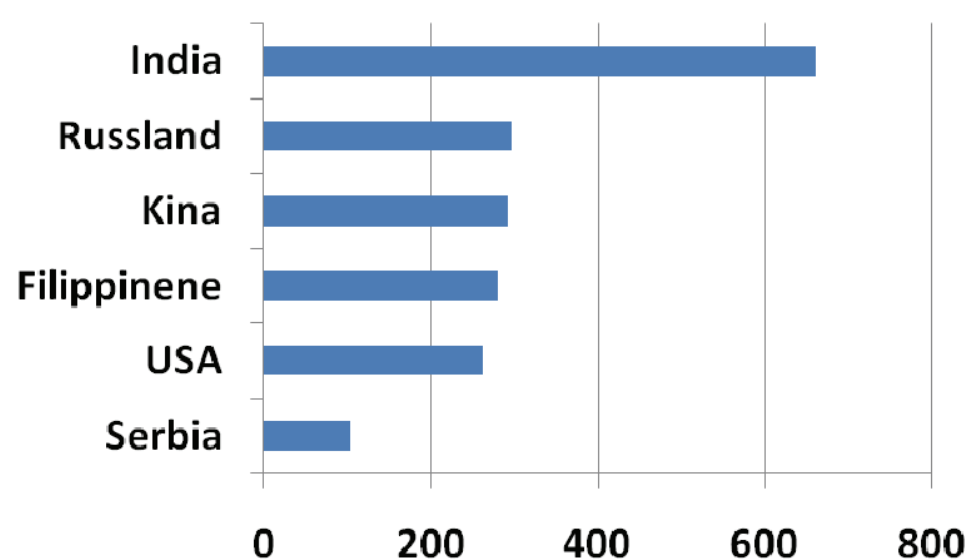

Figur 3 Antall førstegangs arbeidstillatelser som faglert/spesialist i 2008 fordelt etter land. Kilde UDI.

${ }^{133}$ Tall fra UDI «Innvilgede arbeidstillatelser 2000-2008». Alle EU/EØS-land er tatt ut av statisikken, inkludert Polen, Litauen, Bulgaria og Romania, som alle representerte en betydelig andel av arbeidstillatelsene også før innlemmelsen i EU. 


\subsubsection{Mobilitet blant ingeniører - manglende statistikk}

I Norge finnes ingen samlet registrering av antallet utenlandske ingeniører som jobber i Norge. Ingeniører som innvandrer til Norge fra land utenfor EU/EØS-området søker om oppholdstillatelse innenfor den samme kvoten som andre faglærte og spesialister. Utlendingsmyndighetene fører register over denne innvandringen og registrerer bransje, yrke og utdanning til søkerne. Innenfor kvoteordningen er det i all hovedsak utdanningsnivå som er avgjørende for om søkeren får oppholdstillatelse. Dersom utdanningsnivået tilfredsstiller kravet til opphold, vil registreringen av type utdanning og yrke etter statistiske kategorier være å anse for tilleggsopplysninger som ikke har direkte relevans for oppholdstillatelsen. UDI anser registreringen av disse opplysningene for usikre, og har ikke gjort disse dataene offentlig. Dette medfører at det ikke finnes offentlige registerdata som viser antallet ingeniører innvandret til Norge fra tredjeland.

Et pålitelig register over yrke og kompetanse til arbeidssøkere fra tredjeland ville gi kunnskap om hva slags arbeidskraft som etterspørres av norsk næringsliv, og hvilken betydning den globale arbeidsinnvandringen har for høyt utdannet arbeidskraft.

En undersøkelse gjennomført blant medlemsbedriftene i arbeidsgiverog bransjeorganisasjonen Norsk Industri, gir noe informasjon om norske industribedrifters bruk av utenlandske ingeniører. $11 \%$ av medlemsbedriftene i Norsk Industri svarte i november 2006 at bedriften hadde ansatt eller innleid en eller flere utenlandske ingeniører (Seip 2007). Tabell 5 viser at 4,5\% av bedriftene hadde ansatt eller innleid en ingeniør fra tredjeland, det vil si et land utenfor EU/EØS-området. Blant bedriftene som benyttet seg av utenlandsk arbeidskraft var det $32 \%$ som hadde en eller flere utenlandske ingeniører ansatt eller innleid.

Tabell 5 Andel medlemsbedrifter i Norsk Industri som har ansatt eller innleid en eller flere utenlandske ingeniører, november 2006.

\begin{tabular}{lrr}
\hline & $\begin{array}{r}\text { Prosent av alle } \\
\text { bedriftene som } \\
\text { bruker utenlandsk } \\
\text { arbeidskraft (N=205) }\end{array}$ & $\begin{array}{r}\text { Prosent av alle } \\
\text { bedriftene (N=587) }\end{array}$ \\
\hline Bruker utenlandske ingeniører & $32 \%$ & $11 \%$ \\
Bruker ingeniører fra tredjeland & $13 \%$ & $4,5 \%$ \\
Bruker utenlandske ingeniører bare fra EU/EØS-området & $19 \%$ & $6,5 \%$ \\
\hline
\end{tabular}

Kilde: Fafo

\subsubsection{EURES}

EURES (European Employment Service) ble opprettet i 1993 for å bistå med å skape et europeisk arbeidsmarked. EURES er et samarbeidsnettverk mellom Europakommisjonen, de offentlige arbeidsmarkedsetatene i EU/EØS, og partene i arbeidslivet. I Norge er EURES en del av NAV. 
EURES har som målsetting å bistå med informasjon, råd og rekruttering over landegrensene i Europa. En av de felleseuropeiske erfaringene fra arbeidet med rekruttering av høyt utdannet arbeidskraft er at det europeiske arbeidsmarkedet er for lite. Det er derfor lagt planer for å utvide rekrutteringsområdet for EURES til også å omfatte Russland, Kina, India og Pakistan.

En undersøkelse fra 2007 viste at EURES bare i begrenset grad brukes som rekrutteringskanal når industribedriftene henter inn utenlandsk arbeidskraft (Seip 2007:30). For enkelte bedrifter har imidlertid samarbeidet med EURES vært viktig.

EURES har over 700 konsulenter over hele Europa, som til daglig er i kontakt med arbeidssøkere. Det arbeides ikke etter et standardisert konsept, og dette medfører at EURES' tjenester kan variere med hvordan den enkelte konsulent jobber.

I tiden forut for finanskrisen forsøkte EURES i Norge å imøtekomme den store etterspørselen etter ingeniører og sivilingeniører ved å arbeide særskilt mot dette rekrutteringsmarkedet. Norske ingeniørjobber ble profilert i hele EURES-området, og EURES i Norge er i ferd med å bygge opp en egen base med CVer over jobbsøkende ingeniører og andre kompetansegrupper. For å gjøre det lettere for arbeidsgivere og arbeidssøkere å møte hverandre har enkelte EURES-konsulenter satset på å etablere messer. Arbeidssøkere og arbeidsgivere inviteres til slike messer, som gjerne er lukkede, hvor de møtes og kan drøfte jobbmuligheter og foreta jobbintervjuer. I noen tilfeller har arbeidsgivere på forhånd fått tilsendt jobbsøkernes CV, og kan møte til forberedte jobbintervjuer. EURES formidler stillinger, men fører ikke statistikk over hvilke formidlinger som fører til endelig ansettelse.

EURES har også samarbeid med private rekrutteringsselskaper. På samme måte som enkeltstående arbeidsgivere går rekrutteringsselskapene gjennom CVene EURES formidler og plukker ut aktuelle kandidater for sine oppdragsgivere.

\subsubsection{Partene på arbeidsmarkedet - erfaringer og synspunkter}

Norge har to organisasjoner for ingeniører. NITO organiserer ingeniører og teknologer med høyskole-/universitetsutdanning eller tilsvarende kompetanse, og oppgir å ha 62000 medlemmer. NITO står ikke tilsluttet noen hovedorganisasjon.

Tekna - Teknisk-naturvitenskapelig forening har medlemmer med masterutdanning innenfor teknologi og naturvitenskap, og oppgir å ha 52000 medlemmer i forskjellige yrkessituasjoner, også selvstendig næringsdrivende. Tekna er medlem av hovedorganisasjonen Akademikerne.

Både NITO og Tekna har medlemmer i offentlig og privat sektor. I privat sektor er det NHO og Spekter som er de viktigste arbeidsgiverpartene for ingeniørgruppene. Arbeidsgiverpart i tariffavtalene i offentlig 
sektor er KS for kommunene og Fornyings- og administrasjonsdepartementet i staten.

Ingeniørorganisasjonene NITO og Tekna har ingen oversikt over antallet utenlandske ingeniører i norsk arbeidsliv i dag, men har inntrykk av at det spesielt innenfor olje og IKT finnes en del utenlandske ingeniører. Ifølge NITO vurderer norske og internasjonale virksomheter hele tiden behovet for å rekruttere ingeniører til Norge opp mot muligheten av å flytte virksomhet ut. Et eksempel på det siste er IT-tjenester som er blitt flyttet til India.

Verken NITO og Tekna har satt rekruttering av utenlandske ingeniører i sentrum. Medlemsmassen er dermed ingen god indikator på omfanget av utenlandske ingeniører i Norge. Gjennom ordningen med gjestemedlemskap for ingeniører i Norden, har NITO og Tekna fått inntrykk av at det særlig er svenske og, i det siste, også islandske ingeniører som har kommet til Norge. Dette dreier seg om noen hundre ingeniører som har registrert et slikt medlemskap. Det har vært noe kontakt med ingeniører fra andre land også, og etter forespørsel fra tillitsvalgte i et norsk ITselskap ble NITOs søknadsskjema oversatt til engelsk.

Ingeniører fra Asia har vært innleid til større norske engineeringselskaper. NITOs erfaring er at arbeidstakere fra land som for eksempel India og Indonesia er skeptiske til fagforeningstilknytning.

NITO og Tekna har ikke opplevd at press på lønninger eller arbeidsbetingelser har vært noe problem knyttet til bruk av utenlandske ingeniører. Både NITO og Tekna støtter økt innvandring av ingeniører, slik at Norge kan opprettholde et framtidsrettet og attraktivt miljø når det gjelder forskning, utvikling og produksjon. Tekna etterlyser en internasjonalt rettet helhetlig strategi for å rekruttere høyt utdannede til norsk arbeidsliv og studenter til norske utdannings- og forskningsinstitusjoner. Organisasjonen legger også vekt på at det legges bedre til rette for at de som kommer til Norge for å studere og forske, blir værende i landet.

Arbeidsgiver- og bransjeorganisasjonene Norsk Industri og Oljeindustriens Landsforening har begge i flere år hatt oppmerksomheten rettet mot behovet for å rekruttere ingeniører fra utlandet. Norsk Industri gjennomfører interne spørreundersøkelser for å kartlegge behovet for ingeniører i sine bedrifter. Undersøkelsene blir ikke publisert, men organisasjonen har gitt uttrykk for at de tror behovet for ingeniører vil øke. Norsk Industri er positiv til at myndighetene har økt bevilgningene til ingeniørutdanning. ${ }^{134}$ I framtiden vil helsevesenet trenge flere ingeniører. Utviklingen innen miljø og energi vil også skape et økt behov for ingeniører.

Norsk Industri ser ikke innvandring av høyt utdannet arbeidskraft som et spørsmål om volum, og peker på at medlemsbedriftene ikke har behov for så forferdelig mange med topputdanning. Den eksisterende kvoten for innvandring fra tredjeland er dermed ikke noe problem. Det som imidlertid er viktig for industribedriftene er å kunne ta i bruk arbeidskraften

\footnotetext{
${ }^{134}$ Ved revidert nasjonalbudsjett 2009 har økte bevilgninger blant annet gått til ingeniørutdanning.
} 
raskt, og unngå vanskelige og tidkrevende søknads- og godkjenningsprosesser. Forslaget til «fast track» i de nye forskriftene tilfredsstiller trolig bedriftenes behov.

Også ingeniørorganisasjonen Tekna mener kapasiteten og kvaliteten i norske utdanningsinstitusjoner er avgjørende for at Norge skal ha en god tilgang på ingeniørarbeidskraft, men understreker at det parallelt må legges til rette for at norske virksomheter skal kunne tiltrekke seg høyutdannet kompetanse fra utenlandet. ${ }^{135}$

\subsubsection{Saksbehandlingstid}

Saksbehandlingstiden for søknader om oppholdstillatelse for å arbeide, kan variere. UDI peker på at det er flere forhold som kan være årsak til dette. Hvem som skal behandle søknaden (politi, utenriksstasjon og UDI) og hvor mange instanser som skal konsulteres (for eksempel Statens autorisasjonskontor for helsepersonell), vil ha betydning. Saksbehandlingstiden vil også variere i ulike perioder etter arbeidsmengden hos de ulike myndighetene. ${ }^{136}$ UDI har angitt saksbehandlingstiden for en faglært eller spesialist fra tredjeland fra fire til fem måneder. ${ }^{137}$ Regjeringen opprettet i 2007 et informasjons- og servicesenter for arbeidsinnvandrere i Oslo. Senteret samlet representanter for de ulike myndighetene som er involvert i saksbehandlingen ved søknader om oppholds- og arbeidstillatelse. I løpet av 2008 behandlet kontoret 15000 søknader om arbeidstillatelse, inkludert søknader fra Sentral- og Øst-Europa. $74 \%$ av søknadene ble behandlet i løpet av fem arbeidsdager.

Regjeringen satte i sin stortingsmelding et mål om at maksimal saksbehandlingstid for søknader om arbeidstillatelse ikke skal være mer enn 4 uker fra fullstendig søknad er mottatt til vedtak er fattet. Dette forutsetter imidlertid blant annet at nytt regelverk er på plass og at elektronisk saksbehandling i utlendingsforvaltningen er implementert, og at dokumentasjonen lar seg verifisere. ${ }^{138}$

\subsubsection{Arbeidsledighet og framtidig behov for ingeniørkompetanse}

Norge hadde fram mot 2008 et stort behov for ingeniører og mange ledige ingeniørstillinger. Tilgangen på stillinger innenfor ulike ingeniørfag økte i årene fram mot 2008, og gir en indikasjon på den store etterspørselen som fantes. Deler av denne etterspørselen ble forsøkt dekket ved ansettelser av utenlandske ingeniører. Tabell 6 viser tilgangen på ledige stillinger gjennom Arbeids- og velferdsetaten (NAV) og dagspressen. Endringer i registreringen har gjort at vi har valgt bare å vise tall for to av yrkeskategoriene for tiden før 2006.

\footnotetext{
${ }^{135}$ Teknas innspill til Stortingsmelding om arbeidskraftinnvandring, 30. april 2008.

${ }^{136}$ UDIs informasjon: http://www.udi.no/templates/Page.aspx?id=8679

${ }^{137}$ Eldring (2009).

${ }^{138}$ St.meld. nr. 18 (2007-2008), s. 31.
} 
Tabell 6 Tilgang på ledige stillinger fordelt på yrker. Sum i løpet av året.

\begin{tabular}{|c|c|c|c|c|c|c|c|c|c|}
\hline & 2001 & 2002 & 2003 & 2004 & 2005 & 2006 & 2007 & 2008 & $2009^{*}$ \\
\hline $\begin{array}{l}\text { Andre naturviten- } \\
\text { skapelige yrker }\end{array}$ & & & & & & 1297 & 1700 & 1529 & $786^{*}$ \\
\hline Ikt-yrker & & & & & & 9765 & 12523 & 11802 & $4303^{*}$ \\
\hline $\begin{array}{l}\text { Sivilingeniører, } \\
\text { sivilarkitekter o.I. }\end{array}$ & 2491 & 1767 & 1480 & 2065 & 4169 & 7143 & 7792 & 6174 & $2780^{*}$ \\
\hline $\begin{array}{l}\text { Ingeniører og } \\
\text { teknikere }\end{array}$ & 6409 & 3472 & 2687 & 4081 & 7094 & 9818 & 12041 & 11974 & $5100 *$ \\
\hline $\begin{array}{l}\text { Sum ingeniør- } \\
\text { og ikt-fag }\end{array}$ & & & & & & 28023 & 34056 & 31479 & 12 969* \\
\hline
\end{tabular}

* Tallene for 2009 gjelder bare perioden januar t.o.m. august. Estimert årsgjennomsnitt for 2009 (Sum ingeniør- og ikt-fag), basert på de åtte første månedene, vil være 19454.

Kilde: Arbeids- og velferdsdirektoratet 2008 Historisk arbeidsmarkedsstatistikk. Samlet statistikk til og med 2008, tabell 22.

Arbeidsledighetstallene for ingeniører i Norge forteller også om et svært stramt arbeidsmarked. Tabell 7 viser at arbeidsledigheten blant ingeniører i Norge gjennom hele første halvdel av 2009 lå godt under gjennomsnittet.

Tabell 7 Helt arbeidsledige i slutten av hver måned i 2009 fordelt på yrke, i \% av arbeidsstyrken 2008.

\begin{tabular}{lrrrrrrrrr}
\hline & Jan & Feb & Mar & Apr & Mai & Jun & Jul & Aug $\begin{array}{r}\text { Gj.snitt for } 8 \\
\text { mnd. i 2009 }\end{array}$ \\
\hline Ingeniør- og ikt-fag & 0,9 & 1 & 1,1 & 1,2 & 1,2 & 1,3 & 1,5 & 1,4 & 1,2 \\
Alle yrker & 2,6 & 2,7 & 2,8 & 2,8 & 2,6 & 2,7 & 3 & 3 & 2,8 \\
\hline
\end{tabular}

Kilde: Arbeids- og velferdsdirektoratet, Statistikk og utredning. Månedsstatistikk august 2009.

NAV gjennomfører også undersøkelser av bedriftenes behov for arbeidskraft to ganger i året. Tallmaterialet fra disse spørreundersøkelsene brukes til å beregne det udekkede behovet for arbeidskraft også for enkelte yrkesgrupper.

Det vil alltid være usikkerhet forbundet med estimater over framtidig behov og tilgang på kompetanse. Ved inngangen til 2007 oppga norske industribedrifter et betydelig behov for ingeniørkompetanse, og at de hadde problemer med å rekruttere nok ingeniører. ${ }^{139}$ Denne situasjonen endret seg noe med den økonomiske krisen. Sommeren 2009 meldte Norsk Industri om en dobling av arbeidsledigheten blant ingeniører og sivilingeniører, skjønt på et svært lavt nivå, til 1,3 \%. ${ }^{140}$ Oljesektoren i norsk industri ble trolig senere rammet av innskrenkninger enn mange andre næringer, for i februar 2009 annonserte industrikonsernet Aker Solutions at selskapet i inneværende år hadde planer om å ansette 300 nye sivilingeniører. ${ }^{141}$ Etter at den økonomiske krisen begynte å gjøre seg gjeldende, ble imidlertid oppmerksomheten i industrien generelt flyttet fra et kortsiktig rekrutteringsbehov over til den langsiktige tilgangen på ingeniørkompetanse gjennom utdanningssystemet.

\footnotetext{
${ }^{139}$ Seip 2007:17.

${ }^{140}$ http://www.norskindustri.no/arbeidsrett-tariff/fortsatt-oekning-i-industrien-article3441-481.html

${ }^{141}$ Teknisk Ukeblad 16.02.2009, http://www.tu.no/industri/article198983.ece
} 
Norsk Industri peker på at de framtidige utfordringene ligger i utdanningssystemet. ${ }^{142}$ Det er kompetansen fra universitet og høyskoler som vil være avgjørende for industrien i tiden framover. Utdanning i Norge er billig og dermed attraktiv. Norge har en ordning med lønn under doktorgradsutdanning (Ph.D). Dette er et konkurransefortrinn internasjonalt, og ordningen kan brukes slik at Norge får tak i noen av de beste studentene. Det er også viktig å gjøre utdanningene i Norge mer utviklingsorienterte og næringslivsrelaterte. Samarbeidet mellom universitets- og høyskolesektoren og næringslivet bør styrkes, ifølge Norsk Industri.

Skal vi satse på å tilby utenlandske studenter studieplasser i Norge, er det viktig at vi får beholde denne arbeidskraften i Norge. Det må legges til rette for en enkel overgang fra studier til norsk arbeidsliv. Ferdig utdannede studenter vil det bli rift om internasjonalt. Norsk Industri viser til Nederland, som har satt i gang en talentordning for å tiltrekke seg høyt utdannet arbeidskraft fra tredjeland. Innenfor en kvote på 500 vil utenlandske akademikere og nyutdannede med doktorgrad kunne få oppholdstillatelse i ett år for å kunne søke arbeid i Nederland. ${ }^{143}$

Statistisk sentralbyrås framskrivninger av størrelsen på ungdomskullene viser at det i 2020 vil være over 150000 flere i aldersgruppen 19-30 år sammenlignet med 2008. Dette tilsvarer en økning på over $20 \%$, og økningen vil være størst tidlig i perioden. ${ }^{144}$ Dersom studietilbøyeligheten holder seg stabil, viser framskrivninger av rene demografiske effekter at det vil være om lag 277000 studenter i Norge i 2025. Dette tilsvarer en økning på nærmere 63000 studenter fra 2008. Nasjonalt sett vil det være en stor utfordring å imøtekomme utdanningsbehovet for de voksende ungdomskullene. Dersom det satses på å øke kapasiteten ved ingeniørutdanningene, vil veksten i ungdomskullene kunne bidra til å øke tilgangen på ingeniørkompetanse i Norge.

Ingeniørorganisasjonen Tekna har vært kritisk til Statistisk sentralbyrås framskrivninger og fryktet at de undervurderer det framtidige behovet for ingeniørkompetanse. Selv om olje- og gassektoren i Norge etter hvert vil utfases, er det usikkerhet knyttet til prognoser. De fanger vanligvis ikke opp teknologidrevne strukturelle endringer, påpekte Tekna, som mener behovet for ingeniører i framtiden ville vokse, og viser blant annet til miljøutfordringene. ${ }^{145}$

Industrien peker på at Norge har hatt noe lettere tilgang på ingeniører i 2009. Den økonomiske krisen har dempet den innenlandske etterspørselen etter arbeidskraft, og samtidig gitt en flyt av ingeniører fra Gøtebog-området inn i Oslofjordområdet. Det svenske arbeidsmarkedet har over lengre tid fungert som en unik arbeidskraftreserve for Norge. Dette viser at det internasjonale arbeidsmarkedet er viktig for Norge, og indikerer at behovet for

\footnotetext{
${ }^{142}$ Intervju 18.08.2009.

${ }^{143}$ Forslag fra den nederlandske regjeringen om en talentordning, pressemelding datert 27.06.2008, Kabinet akkoord met nieuw toelatingsbeleid voor Nederland, http://www.regering.nl/

${ }^{144}$ St.meld. nr. 44 (2008-2009) Utdanningslinja, s. 66.

${ }^{145}$ Brev fra Tekna til statsråd Tora Aasland, Kunnskapsdepartementet, 2. september 2008.
} 
ingeniører fra tredjeland kan bli stort dersom den nødvendige kompetansen ikke er tilgjengelig på det nordiske eller europeiske arbeidsmarkedet.

\subsection{Nasjonale utfordringer i rekrutteringspolitikken}

\subsubsection{Regulering}

Norge vedtok i 2008 en ny utlendingslov, og har i den forbindelse foretatt endringer i regelverket for arbeidsinnvandring.

Regelverket som gjelder arbeidsinnvandring fra tredjeland stiller et generelt krav om at det skal foreligge tilbud om arbeid. Det stilles også et kompetansekrav som faglært eller spesialist, og et krav til arbeidsmarkedsvurdering. Spesialister defineres ut fra en lønnsterskel på NOK 500000 (ca EUR 55 000). En oppholdstillatelse til faglærte og spesialister gir etter tre år mulighet for å søke permanent oppholdstillatelse i Norge.

Som et unntak fra det generelle kravet til arbeidsmarkedsvurdering er det satt opp en kvote på 5000 tillatelser som kan gis uten at det foreligger en konkret arbeidsmarkedsvurdering. Innenfor kvoten stilles det krav til kompetanse som må være på nivå med fagutdanning eller spesialistkompetanse.

Regelverket åpner for at nyutdannede studenter fra tredjeland kan søke om oppholdstillatelse i inntil seks måneder for å søke arbeid som faglært eller spesialist i Norge.

\subsubsection{Strategier}

Lov- og regelverk som gjelder oppholds- og arbeidstillatelser i Norge har i alt vesentlig vært innrettet mot etterspørselsstyrt innvandring. Innvandring fra tredjeland har skjedd ved at arbeidsgiver har valgt ut og tilbudt jobb til utenlandske arbeidstakere, som så har søkt om oppholds og arbeidstillatelse. Myndighetene har gjennom de seneste års endringer forsøkt å legge enda bedre til rette for etterspørselsstyrt innvandring ved å forenkle prosedyrene som arbeidsgiver og arbeidssøker må forholde seg til.

Norske myndigheter har vurdert, men ikke ønsket, å foreslå mer tilbudsstyrte systemer som for eksempel Blue Card-ordninger. Et unntak fra dette er at regelverket for utenlandske studenter i Norge som ønsker å søke arbeid etter endt utdanning er blitt endret, slik at det er blitt mulig for studentene å bli og arbeide i Norge etter endt utdanning.

Partene på arbeidsmarkedet har stort sett vært tilfreds med reguleringen på området. Arbeidsgiverorganisasjonene har gitt uttrykk for at regelverket bør forenkles, og har støttet myndighetenes arbeid. Arbeidstakerorganisasjonene har også vært positive til den eksisterende reguleringen. Dels skyldes dette at lønns- og arbeidsvilkår i henhold til reguleringen skal holdes på nivå med tariffavtaler og praksis i bransjen, dels skyldes det trolig at den etterspørselsstyrte rekrutteringspolitikken har gitt en 
innvandring som har vært svært godt tilpasset virksomhetenes behov og dermed gitt mindre reelt press på lønninger.

I tråd med en etterspørselsstyrt rekrutteringspolitikk har myndighetene i liten grad drøftet tiltak for særskilte grupper som for eksempel ingeniører. Myndighetene har overlatt til virksomhetene og private aktører å legge til rette for arbeidsinnvandring, bortsett fra å tilby generelle offentlige tiltak rettet mot alle innvandrergrupper, som for eksempel kurs i norskopplæring. I stortingsmeldingen om arbeidsinnvandring la imidlertid regjeringen vekt på at informasjonen om det norske arbeidsmarkedet og søknadsprosessen burde forbedres, og at det burde utredes hvordan utenrikstjenesten kunne brukes for å markedsføre jobbmuligheter i Norge. ${ }^{146}$ Utlendingsdirektoratet fikk i 2009 utarbeidet en rapport om hvordan kommunikasjon kan brukes for å rekruttere høyt utdannet arbeidskraft til Norge. ${ }^{147}$

\subsubsection{Realiteter}

Vi har svært lite statistisk kunnskap om utenlandske ingeniører i Norge. UDI har ikke pålitelige tall for særskilte utdanningsgrupper. Norsk Industri gjør interne undersøkelser om behovet for arbeidskraft, herunder ingeniører, men har ingen oversikt over tallet på utenlandske ingeniører i sine medlemsvirksomheter. Foreliggende surveymateriale på bedriftsnivå antyder at det i industrien er mellom 10-15 \% av virksomhetene som benytter ingeniører fra tredjeland.

Det er grunn til å tro at språk er en viktig faktor som hemmer rekruttering av ingeniører til Norge. Et generelt lavt til moderat lønnsnivå for ingeniører i norske virksomheter kan også ha betydning for enkelte typer ingeniørgrupper og for volumet på innvandringen. For en rekke typer ingeniørtjenester vil imidlertid virksomhetene være villig til å betale den internasjonalt baserte markedslønnen, og lønnsnivået i Norge vil ha liten relevans for disse gruppene. Lønnsnivået kan likevel spille en betydning for rekrutteringen til ingeniørstillinger i offentlig sektor. Store og internasjonalt kjente virksomheter vil trolig ha en større tiltrekningskraft på utenlandsk arbeidskraft enn mer ukjente virksomheter. For Norges del fyller kjennskapet til olje- og gassektoren i utlandet en slik funksjon. Det er også olje- og gassektoren, sammen med leverandørindustrien, som etterspør flest ingeniører og som har kapasitet og betalingsevne til å hente inn det nødvendige antallet ingeniører til Norge, og internasjonalisere den norske delen av ingeniørstokken.

\footnotetext{
${ }^{146}$ Hovedinnhold i St.meld. nr. 18 (2007-2008) «Arbeidsinnvandring», s. 31.

${ }^{147}$ DIFI (2008).
} 


\section{Kilder og referanser}

Kvalitative intervjuer og samtaler er gjennomført med:

Steinar Simonsen, organisasjonssjef NITO

Håvard Lismoen, utreder NITO

Linda Ehnmark, politisk rådgiver Tekna

Madhukar Rohgati, tidligere direktør

Adecco

Carla A. M. Botten-Verboven, direktør Norsk Industri

Kari Hoff Okstad, fagsjef Norsk Industri

Referanser:

Chaloff and Lemaitre (2009) «Managing Highly-Skilled Labour Migration: A Comparative analysis of Migration Policies and Challenges in OECD Countries», OECD Social, Employment and Migration Working Papers $\mathrm{N}^{\circ} 79$.

DIFI (2008) «Utenlandsk arbeidskraft i sikte? Hvordan kommunikasjon kan brukes for å rekruttere flere kloke hoder til Norge», DIFI rapport 2008:11.
Eldring, Line (2009) Labour migration policies in good and bad times: Outlook from Norway. Peer Review on «Renewed procedures for employing migrant workers with the emphasis on favouring highly-qualified labour» Estonia, 11-12 June 2009.

Høring (2009) Forslag til regelverk for å følge opp forslag i St.meld. nr.18 (2007-2008) Arbeidsinnvandring og forslag til forskrifter til ny utlendingslovs kapittel 3 om arbeid og studier mv. http://www.regjeringen.no/ nb/dep/aid/dok/hoeringer/hoeringsdok /2009/horing---forslag-til-regelverkfor-a-fol/horing---forslag-tilregelverk-for-a-fol.html?id=559395 NOU 2004:20 «Ny utlendingslov». Seip, Åsmund Arup (2007) Jakten på kompetanse. Bruk av utenlandsk arbeidskraft i norsk industri. Oslo: Fafo-rapport 2007:12.

Stortingsmelding nr. 18 (2007-2008) Arbeidsinnvandring. 



\section{Sverige}

Sofia Murhem och Andreas Dahlkvist

\subsection{Nationell lagstiftning rörande arbetskraftsinvandring från tredje land}

\subsubsection{Gällande regelverk för arbetskraftsinvandring från tredje land}

Sveriges lagstiftning rörande arbetskraftsinvandring från tredje land är relativt ny. Den 15 december 2008 trädde de nya tillägg ${ }^{148}$ till utlänningslagen som behandlar arbetskraftsinvandring i kraft. Förändringen av reglerna följer en tydlig ambition att underlätta för personer från tredje land att arbeta i Sverige ${ }^{149}$ och flera förenklingar har gjorts i relation till tidigare lagstiftning. Även om ändringarna i regelverket inte primärt syftar till att främja invandring av högkvalificerad arbetskraft till Sverige innebär den nya lagstiftningen en förenkling också för denna grupp.

Generellt gäller att en person från tredje land som vill arbeta i Sverige behöver uppehålls- och arbetstillstånd innan inresa till landet. Den nya lagstiftningen medger dock vissa undantag när det gäller denna punkt och under vissa omständigheter är det är möjligt att söka uppehållstillstånd med syfte att arbeta även inifrån Sverige, exempelvis efter avslag på asylansökan, i samband med inresa för rekryteringssamtal med arbetsgivare, samt vid förnyelse av tidigare beviljat tillstånd. ${ }^{150}$

Uppehållstillstånd för arbete kan ges för maximalt två år med möjlighet till förlängning ytterligare två år så länge personen ifråga har en anställning i Sverige. Under de inledande två åren ska dock tillståndet vara knutet till både till en särskild arbetsgivare och till en viss typ av arbete. När tillståndet förlängs ska det $\mathrm{i}$ fortsättningen även vara knutet till en viss sorts arbete. ${ }^{151} \mathrm{Om}$ en person från tredje land under en femårsperiod haft uppehållstillstånd i syfte att arbete under fyra av dessa ska dock ett permanent uppehållstillstånd kunna utfärdas. ${ }^{152}$

Eftersom grundregeln förutsätter att en tredjelandsmedborgare har fått uppehållstillstånd med syfte att arbeta innan inresa till Sverige krävs det i de flesta fall att själva rekryteringen redan är klar och personen erbjudits

\footnotetext{
${ }^{148}$ SFS 2008:884.

${ }^{149}$ Proposition 2007/2008:147.

${ }^{150}$ SFS 2005:716, 5 kap 18 §.

${ }^{151}$ SFS 2005:716, 6 kap 2 §.

${ }^{152}$ SFS 2005:716, 5 kap 5 §.
} 
en anställning. Lagen slår även fast att uppehålls- och arbetstillstånd endast kan ges om anställningen gör det möjligt för personen i fråga att försörja sig och att lön, försäkrings- och övriga anställningsvillkor inte är sämre än de villkor som gäller på den svenska arbetsmarknaden. ${ }^{153}$ Dessutom kan uppehållstillstånd beviljas om en utlänning har sin försörjning garanterad på annat sätt än genom anställning. Om detta säkerställs genom egen näringsverksamhet ska dock vederbörande bedömas ha förmågan att driva denna på ett godtagbart sätt. ${ }^{154}$

Den nya lagstiftningen ger dock arbetsgivaren ett mycket stort ansvar, då det är upp till denne att göra en bedömning av behovet av arbetskraft och möjligheten att rekrytera kompetent personal i Sverige eller inom det övriga EU/EES-området. ${ }^{155}$ Enligt regelverket måste ett rekryteringsförfarande gällande arbetskraft från tredje land vara förenligt med Sveriges åtaganden inom EU, vilket innebär att arbetsgivaren är skyldig att på vederbörligt sätt utannonsera den aktuella tjänsten inom EU och EESländerna innan det kan bli aktuellt att rekrytera någon från tredje land. Handläggande myndighet, som är Migrationsverket, har det formella ansvaret för att se till att anställningen inte står i strid med svenska löner och villkor, även om lagstiftningen betonar att detta är något som i första hand ska diskuteras mellan arbetsgivaren och berörda arbetstagarorganisationer, samt att Sveriges åtagande gentemot EU efterlevs i samband med rekrytering av någon från tredje land. ${ }^{156}$

I praktiken innebär reglerna att en arbetsgivare ska göra det möjligt för personer bosatta i Sverige och EU/EES-området att söka den aktuella tjänsten, vilket i normalfallet ska göras genom utannonsering via Arbetsförmedlingen, och därmed också EURES, under minst tio dagar. När detta krav är tillgodosett ska arbetsgivaren upprätta ett s.k. anställningserbjudande, där uppgifter om den aktuella anställningen redovisas. Innan ett arbetstillstånd beviljas ska arbetsgivaren också begära in yttrande från berörda fackliga organisationer, något som normalt görs genom att arbetsgivaren låter den aktuella arbetstagarorganisationen komplettera anställningserbjudandet med ett yttrande om villkoren för anställningen. Slutligen bifogar berörd arbetstagare anställningserbjudandet till sin ansökan om uppehålls- och arbetstillstånd. ${ }^{157}$

Även om den nya lagstiftningen ger arbetsgivaren en central roll i bedömningen av behovet av arbetskraft finns vissa regler som underlättar anställning av arbetstagare inom särskilda bristområden. Dessa regler gäller möjligheten för arbetstagare som besöker en arbetsgivare i Sverige, för att göra en anställningsintervju eller liknande, att söka uppehålls- och arbetstillstånd efter inresa till landet. Ett krav för att göra detta är dock att det råder stor efterfrågan på arbetskraft inom det aktuella yrket. Med

\footnotetext{
${ }^{153}$ SFS 2005:716, 6 kap 2 §.

${ }^{154}$ SFS 2005:716, 5 kap 5 §.

${ }^{155}$ Se Proposition 2007/2008:147, s. 26.

${ }^{156}$ Proposition 2007/2008:147, s. 35 ff.

${ }^{157}$ www.migrationsverket.se.
} 
jämna mellanrum publicerar Migrationsverket också en förteckning över yrken där det råder brist på sin webbplats.

\subsubsection{Utveckling av regelverket för arbetskraftsinvandring}

Genom 2008 års omarbetning av utlänningslagen förändrades det svenska regelverket rörande invandring av arbetskraft från tredje land och blev betydligt liberalare. Den huvudsakliga motiveringen till denna liberalisering var att göra det svenska systemet mer flexibelt och därmed främja en mer omfattande arbetskraftsinvandring från tredje land. Den tydligaste förändringen var avskaffandet av den så kallade myndighetsbaserade arbetsmarknadsprövningen, inom vilken det gjordes en bedömning av bristen på arbetskraft. Denna prövning innebar även att Arbetsförmedlingen ansvarade för inhämtandet av uppgifter om lön, avtalsvillkor etc. från berörda arbetstagarorganisationer för att bedöma om den aktuella anställningen var förenlig med gällande villkor i Sverige. Dessutom var Arbetsförmedlingen tidigare ansvarig för att en anställning i första hand skulle gå till svenska eller EU-/EES-medborgare, d.v.s. att det så kallade gemenskapsföreträdet skulle tillgodoses. Även om tillståndet redan tidigare handlades av Migrationsverket, var Arbetsförmedlingen ansvarig myndighet för kontroll av villkoren för beviljandet. Istället är det nu arbetsgivarens bedömning av att det finns ett behov av rekrytering av arbetskraft utanför EU/EES som utgör grunden för uppehålls- och arbetstillstånd. I denna bemärkelse är alltså den tidigare myndighetsbaserade arbetsmarknadsprövningen avskaffad. ${ }^{158}$ Dessutom har tidigare formuleringar om att arbetstillstånd ska utfärdas inom yrken där det råder brist på arbetskraft strukits till förmån för mer generella villkor rörande möjligheten att försörja sig m.m. ${ }^{159}$ Dock är det värt att notera att vissa specialregler fortfarande gäller arbetssökande inom bristyrken, vilka under vissa omständigheter kan söka uppehålls- och arbetstillstånd efter inresa till Sverige.

Ett exempel på ytterligare en förändring är att den tidigare möjligheten att direkt bevilja permanent arbetstillstånd har tagits bort. Innan 2008 års lagändring var det möjligt för personer som erbjudits en anställning inom ett område, vilket genom den myndighetsbaserade arbetsmarknadsprövningen bedömts som ett bristyrke, att få beviljat ett permanenta uppehållstillstånd för arbete. I och med lagändringen ska istället tillfälliga arbetstillstånd beviljas inledningsvis, för sedan kunna bli permanent om en sökande under de kommande fem åren beviljats tillstånd för arbete under minst fyra av dessa. Regeringen motiverade denna förändring med att den var i linje med överförande av ansvaret för att bedöma behov utländsk arbetskraft från myndigheterna till arbetsgivarna, samt att målsättningen att kortare vistelser i landet för arbete inte ska ligga till grund för

\footnotetext{
${ }^{158}$ Se Proposition 2007/2008:147, s. 25 f.

${ }^{159}$ Proposition 2007/2008:147, s. 9.
} 
ett permanent uppehållstillstånd. Vidare påpekade regeringen att de personer som berörs av denna förändring inte förväntas ha några problem med att få permanent uppehållstillstånd enligt de nya reglerna om de så önskar. ${ }^{160}$

I samband med borttagandet av den myndighetsbaserade arbetsmarknadsprövningen föreslog regeringen även att det tidigare regelverket för säsongsarbetare skulle förändras och att dessa ärenden istället skulle behandlas enligt samma regler som de generella uppehålls- och arbetstillstånden. ${ }^{161}$ Ett borttagande av de speciella regler som gällt för denna grupp blev också resultatet av den nya lagstiftningen.

Vidare förordade regeringen att den bortre gränsen på 18 månader, med möjlighet till förlängning i ytterligare 6 månader, skulle förlängas till två år, med en möjlighet till en sammanlagd tillståndstid om totalt fyra år efter förnyelse av tillståndet. Ytterligare en förändring var införandet av kravet på att alla arbetstillstånd inledningsvis ska kopplas till en viss arbetsgivare och ett visst slag av arbete. ${ }^{162}$

Dessutom ändrades skrivningen rörande villkoren för att bevilja arbetstillstånd. I och med förändringen av utlänningslagen infördes i lagtexten att lön, anställningsvillkor och försäkringsskydd för den arbetssökande tredjelandsmedborgaren inte får vara sämre än de villkor som följer av svenska kollektivavtal eller praxis inom yrket eller branschen. Tidigare åvilade det arbetsmarknadsmyndigheterna att göra denna kontroll, vilket upphörde i och med den nya lagstiftningen. Precis som tidigare ska dock berörd arbetstagarorganisation ges möjlighet att yttra sig i ärendet, men detta ska inhämtas i första hand av arbetsgivaren, och om detta inte görs, av tillståndsmyndigheten Migrationsverket. ${ }^{163}$

I lagen infördes dock flera undantag från tidigare regler om att uppehålls- och arbetstillstånd skulle vara ordnat före inresan i Sverige - t.ex. har den som beviljats visering för att träffa en arbetsgivare i Sverige och som därigenom erbjuds en anställning inom en typ av arbete där det råder stor brist på arbetskraft möjlighet att söka tillstånd i Sverige. ${ }^{164}$ Dessutom öppnade den nya lagen möjligheten för asylsökande, som fått avslag på sin ansökan och haft anställning i Sverige i minst sex månader under asylprocessen, att söka uppehålls- och arbetstillstånd utan att lämna landet. ${ }^{165}$

En ändring av regelverket rörande arbetskraftsinvandring från tredje land har diskuterats i Sverige under flera år. Frågan om en liberalisering av arbetskraftsinvandringen debatterades flitigt redan under valrörelsen 2002. Då avvisade socialdemokraterna och LO tanken på en friare arbetskraftsinvandring, medan de borgerliga partierna stödde idén och Folkpartiet rent av gjorde den till en huvudfråga i valet. Valet vanns dock av

\footnotetext{
${ }^{160}$ Proposition 2007/2008:147, s. 33 f.

${ }^{161}$ Proposition 2007/2008:147, s. $34 \mathrm{f}$.

${ }^{162}$ Proposition 2007/2008:147, s. $30 \mathrm{f}$.

${ }^{163}$ Se Proposition 2007/2008:147, s. 35 ff.

${ }^{164}$ Se SFS 2005:716, 5 kap 18 §.

165 SFS 2008:884, 15, 18 §§.
} 
socialdemokraterna, som bildade egen regering, men med stöd av Vänsterpartiet och Miljöpartiet. Genom att miljöpartiet stödde tanken på ökad arbetskraftsinvandring fanns dock majoritet i kammaren för frågan. Socialdemokraterna tillsatte en utredning som resulterade i socialförsäkringsutskottets betänkande 2002/03:SfU8 Migration och asylpolitik (skr. 2002/03:28). Betänkandet innehöll bara smärre justeringar av den dåvarande regleringen arbetskraftsinvandringen. Mot betänkandet reserverade sig de borgerliga och miljöpartiet, och följaktligen avvisade riksdagen också betänkandet. På riksdagens begäran tillsattes en ny utredning. Samtidigt öppnade socialdemokraterna i olika uttalanden upp för ökad arbetskraftsinvandring inom vissa bristyrken. ${ }^{166}$

Den process som föregick den aktuella lagändringen tog sin början 2004 genom utnämnandet av en parlamentarisk kommitté, vilken fick i uppdrag att se över det regelverk som styrde arbetskraftsinvandring. Syftet med utnämningen var att ta fram en lagstiftning som medgav vidgad arbetskraftsinvandring från länder utanför EU/EES och Schweiz. I direktivet klargjordes att kommittén, som antog namnet Kommittén för arbetskraftsinvandring (KAKI), utöver att se över och föreslå förändringar i rådande regelverk rörande arbetskraftsinvandring, även skulle utreda behovet av arbetskraftsinvandring samt bedöma vilka konsekvenser detta kunde få för svensk arbetsmarknad. ${ }^{167}$ Kommittén redovisade delbetänkandet "Arbetskraftsinvandring till Sverige - befolkningsutveckling, arbetsmarknad i förändring, internationell utblick"168 2005 och lade i oktober 2006 fram slutbetänkandet "Arbetskraftsinvandring till Sverige förslag och konsekvenser" ${ }^{169}$. Efter valet 2006 var de borgerliga partierna i Allians för Sverige eniga om att införa öppen arbetskraftsinvandring från länder utanför EU/EES om arbetsgivaren såg behov av sådan arbetskraft. Folkpartiet hade tidigare ansett att behovet av arbetskraft skulle bedömas av Arbetsmarknadsstyrelsen (AMS), men lämnade den uppfattningen. ${ }^{170}$ Slutbetänkandet låg, tillsammans med de ytterligare förslag som under 2007 presenterades i en promemoria från Justitiedepartementet ${ }^{171}$, till grund för den proposition som regeringen (Moderaterna, Folkpartiet, Centerpartiet och Kristdemokraterna) tillsammans med Miljöpartiet lade fram. Dock avvek propositionen i vissa stycken från KAKI:s slutsatser. Dessutom presenterade remissinstanserna i vissa fall ståndpunkter som gick emot regeringens förslag.

Exempelvis föreslog KAKI i sitt slutbetänkande att den myndighetsbaserade arbetsmarknadsprövningen skulle vara kvar. Såväl propositionen som de flesta remissinstanser förespråkade dock en borttagning av prövningen och en förändring av Arbetsförmedlingens roll. Två av ar-

${ }^{166}$ Riksdagens snabbprotokoll 2002/03:109 2003-05-22.

${ }^{167}$ Direktiv 2004:21.

${ }^{168}$ SOU 2005:50.

${ }^{169}$ SOU 2006:87.

${ }^{170}$ Ekot, Sveriges Radio Alliansen enig om arbetskraftsinvandring 2006-10-11.

${ }^{171}$ Ds 2007:27. 
betsmarknadens parter, Landsorganisationen (LO) och Tjänstemännens centralorganisation (TCO), kritiserade emellertid lagförslaget på denna punkt. Båda organisationerna betonade att det borde ses som orimligt att ge enskilda arbetsgivare så pass stort manöverutrymme som lagändringen skulle innebära och att Arbetsförmedlingens upparbetade kompetens på det aktuella området riskerade att gå förlorad. LO och TCO ansåg vidare att reglerna runt arbetstagarorganisationernas roll borde göras tydligare och LO betonade även att arbetsmarknadens parter borde få yttra sig i själva bristfrågan då de besitter stora kunskaper om arbetsmarknadsläget. ${ }^{172}$ SACO ställde sig dock bakom regeringens principiella resonemang om att avskaffa arbetsmarknadsprövningen, då detta skulle underlätta arbetskraftsinvandring. Dock ansåg organisationen att reglerna runt arbetstagarorganisationernas inblandning i tillståndsprocessen skulle göras tydligare och att de fackliga organisationerna skulle ges tillräckligt med tid för att bidra med information till den aktuella processen. ${ }^{173} \mathrm{Re}-$ geringen motiverade dock sitt ställningstagande med att det är den enskilde arbetsgivaren som har bäst kunskap om vilka rekryteringsbehov som finns och att beslutet därför bör ligga hos dessa.

När det gällde hanteringen av gemenskapsföreträdet gentemot EU/EESländerna och kontrollen av anställningsvillkor föreslog regeringen att tillsynen inom dessa områden skulle falla på Migrationsverket. I propositionen betonas det dock att arbetsgivaren ska ge sammanslutningar av arbetstagare tillfälle att yttra sig över arbetsvillkoren. Om så inte sker ska det, enligt det regeringsförslag som senare antogs, falla på Migrationsverket att fullgöra denna uppgift. ${ }^{174}$ Ett förtydligande av denna ambition gjordes även senare i Utlänningsförordningen, där det dock fastslås att Migrationsverket under vissa omständigheter kan bortse från kravet att inhämta information från berörda arbetstagarorganisationer. ${ }^{175}$

Kommitténs slutbetänkande och propositionen var dock eniga om att tydligare villkor för arbetstillstånd skulle skrivas in i lagtexten, vilket många remissinstanser också var positiva till. När det gällde kravet på att tillfälliga arbetstillstånd ska kopplas till en viss arbetsgivare och ett visst arbete rådde bred enighet mellan utredning, regering och de fackliga centralorganisationerna om att så skulle vara fallet under de två första åren, för att därefter endast kopplas till visst arbete. Svenskt Näringsliv ansåg däremot att detta minskade rörligheten på arbetsmarknaden och att sådana regler inte borde införas. ${ }^{176}$

När det gällde förslaget att öppna upp möjligheterna för före detta asylsökande att söka uppehållstillstånd för arbete förhöll sig flera remissinstanser kritiska. Flera statliga myndigheter, däribland Migrationsverket, påpekade att det aktuella förslaget riskerade att luckra upp separationen

\footnotetext{
172 Ju2007/6628/EMA (LO), Ju2007/6628/EMA (TCO).

173 Ju2007/6628/EMA (SACO).

${ }^{174}$ Se Proposition 2007/2008:147, samt Ds 2007:27.

${ }^{175}$ Se SFS 2008:895.

${ }^{176}$ Ju2007/6628/EMA (Svenskt Näringsliv).
} 
mellan asyl- och arbetskraftsinvandring, samt att det även öppnade upp för missbruk av asylsystemet. ${ }^{177}$ Även de centrala arbetsmarknadsorganisationerna uppmärksammade risken att den föreslagna lagstiftningen skulle kunna urholka asylsystemet. LO och SACO tog också tydligt avstånd från regeringens förslag och motsatte sig de nya reglerna. ${ }^{178}$ Svenskt Näringsliv stödde dock regeringsförslaget om ett öppnande för "spårbyte" mellan asylansökan och arbetskraftsinvandring, vilket senare antogs av riksdagen. ${ }^{179}$

Det fanns även en hel del politiskt motstånd mot vissa delar av regerings förslag. Medlemmar av såväl Socialdemokraterna som Vänsterpartiet kritiserade regeringens proposition och lade fram egna motioner. ${ }^{180}$ Både Socialdemokraterna och Vänsterpartiet var exempelvis kritiska mot borttagandet av den myndighetsbaserade arbetsmarknadsprövningen och yrkade på att Arbetsförmedlingens roll i kontrollen av löner, villkor etc. skulle bibehållas. Dessutom motsatte sig oppositionen de nya reglerna rörande före detta asylsökande med motiveringen att förändringen riskerade att urholka asylrätten. Både dessa motioners förslag avstyrkes dock av den svenska riksdagens socialförsäkringsutskott, vilket i sitt betänkande stödde regeringens förslag. ${ }^{181}$

\subsubsection{EU:s regelverk i relation till den svenska regleringen av arbetskraftsinvandring}

Såväl före som efter förändringen av den svenska lagstiftningen om arbetskraftsinvandring har Sveriges förpliktelser gentemot omvärlden spelat en stor roll för behandlingen av utländska arbetssökande. Genom medlemskapet i EU har Sverige också förbundit sig att se till att lediga anställningar om möjligt ska fyllas med arbetssökande från EU/EES-området innan någon från tredje land kan komma ifråga. Den övervägande skillnaden mellan det nya regelverket och tidigare lagstiftning är dock att avskaffandet av den myndighetsbaserade arbetsmarknadsprövningen har underlättat för arbetsgivare att rekrytera arbetskraft från tredje land, då bedömningen om det finns behov att rekrytera utanför EU/EES-området numera ligger i deras händer. Trots dessa förändringar lever alltså gemenskapsföreträdet kvar som en viktig del i processen runt arbetskraftsinvandring från tredje land.

Även om den svenska regeringen hänvisade till det europeiska regelverket i den proposition som föregick 2008 års lagstiftningsförändring saknas direkta hänvisningar till den europeiska arbetsmarknadsregleringen i relation till lagtexten, bortsätt från diskussioner om att gemenskapsföreträdet ska respekteras. ${ }^{182}$ I det slutbetänkande som presenterades av

${ }^{177}$ Ju2007/6628/EMA (Migrationsverket).

${ }^{178}$ Ju2007/6628/EMA (LO), Ju2007/6628/EMA (SACO).

${ }^{179}$ Ju2007/6628/EMA (Svenskt Näringsliv).

${ }^{180}$ Motion 2007/2008:Sf27 och Motion 2007/2008:Sf28.

${ }^{181}$ Betänkande 2008/2009:SfU3.

${ }^{182}$ Proposition 2007/2008:147. 
KAKI förkom dock en diskussion om betydelsen av EU:s regelverk för den svenska arbetsmarknaden och i en bilaga till utredningen presenterades även förändringar i den europeiska lagstiftningen med betydelse för kommitténs arbete. ${ }^{183}$

När det gäller det EU-direktiv ${ }^{184}$ som behandlar villkoren för tredjelandsmedborgare som är aktuella för högkvalificerade anställningar, vilket inkluderar regler rörande utfärdande av så kallade "EU-blåkort”, finns inga tydliga referenser till något av de preliminära förslag som föregick det slutgiltiga direktivet i den svenska lagstiftningen. Vissa delar av den nya lagstiftningen har dock tydliga likheter med bestämmelserna i direktivet, till exempel reglerna om att ett tidbegränsat arbetstillstånd i inledningsskedet ska vara kopplat till en bestämd arbetsgivare och ett bestämt yrke, vilket tyder på att de tidiga direktivförslagen hade en viss inverkan på den svenska lagstiftningens utformning. ${ }^{185}$ I juli 2009 tillsatte regeringen också en parlamentarisk kommitté ${ }^{186}$, vars uppdrag har en tydlig koppling till det aktuella direktivet. "Kommittén för cirkulär migration och utveckling", vilket var det namn som kommittén gavs, har till sitt uppdrag att kartlägga och analysera den cirkulära migrationen ur ett svenskt perspektiv, lämna förslag till författningsändringar och presentera ett underlag för framtagandet av en svensk politik på detta område. I kommittédirektivet framhävs även vikten av att pågående arbete inom EU ska beaktas. Ett exempel på detta arbete är direktivet rörande EU-blåkort, i vilket underlättandet av cirkulär migration beskrivs som ett viktigt område att arbeta vidare med. Kommittén ska även avlägga sin slutrapport två månader innan det aktuella direktivet ska vara implementerat i medlemsländerna.

I konkreta termer är det samarbete som sker inom EURES (European Employment Service) det tydligaste exemplet på hur det europeiska regelverket påverkat det praktiska arbetsmarknadsarbetet i Sverige. Genom inträdet i EU förband sig Sverige att delta i detta nätvärk för samordning av medlemsstaternas arbetsmarknader. En viktig funktion hos EURES i relation till den nya lagstiftningen är dessutom att nätverket ska ses som ett sätt att utannonsera lediga tjänster inom EU/EES-området innan rekrytering från tredje land kan komma i fråga. EURES är också det tydligaste exemplet på samordning mellan Arbetsförmedlingen och andra myndigheter i relation till arbetskraftsinvandring. Särskilt gäller detta de så kallade "cross border-organisationer" som finns i Skåne och Norrbotten, inom vilka det finns ett samarbete mellan olika myndigheter i Sverige och utomlands. ${ }^{187}$

\footnotetext{
${ }^{183}$ SOU 2006:87.

${ }^{184}$ Direktiv 2009/50/EG.

${ }^{185}$ Se Direktiv 2009/50/EG, Artikel 12.1, samt Proposition 2007/2008:147, s. 30 f.

${ }^{186}$ Dir. 2009:53.

${ }^{187}$ Intervju - Arbetsförmedlingen.
} 


\subsubsection{Arbetsmarknadens parter och arbetskraftsinvandringen}

Den roll som arbetsmarknadens parter vill ha i relation till arbetskraftsinvandringen från tredje land varierar stort. Under det remissförförande som föregick 2008 års lagstiftning gavs de fackliga centralorganisationerna och deras motsvarighet på arbetsgivarsidan, Svenskt Näringsliv, möjlighet att presentera sina ståndpunkter i denna fråga.

LO, som är huvudorganisation för Sveriges löntagare, är den av de fackliga centralorganisationerna som tydligast ser en roll inom arbetskraftsinvandringen och i remissförfarandet propagerade organisationen för att parterna borde vara med och avgöra ett eventuellt behov av arbetskraftsrekrytering från tredje land. I presentationen av organisationens utgångspunkter betonades att arbetskraftsinvandring för att råda bot på "flaskhalsar" på arbetsmarknaden är positivt, men att konkurrenssituationer mellan utländsk och inhemsk arbetskraft riskerar att leda till ökad arbetslöshet. I linje med detta resonemang menade LO att arbetskraftsinvandring principiellt bör tillåtas endast då det finns en brist att fylla. Dessutom betonade organisationen att den arbetskraftsbrist som råder $\mathrm{i}$ lågproduktiva branscher inte bör ses som ett resultat av att inhemsk arbetskraft inte är beredd att utföra dessa arbetsuppgifter utan snarare som ett resultat av att löner, likväl som arbetsförhållanden, ligger på en oacceptabel nivå. Därtill påpekade LO i sitt remissvar att sänkta lönekostnader genom import av lågavlönad arbetskraft kommer att försämra omvandlingstrycket i ekonomin, vilket är negativt för hela samhället. ${ }^{188}$

Precis som LO uttryckte TCO, som är centralorganisation för en rad tjänstemannaförbund, stöd för att arbetskraftsinvandring ska tillåtas om behovet av arbetskraft inte kan tillgodoses på annat sätt. I organisationens remiss påpekades dessutom att det är än viktigare att den arbetskraft som finns inom landet utnyttjas, vilket sades vara något som inte sker idag. Även om TCO inte avfärdade förslaget om avskaffadet av den myndighetsbeprövade arbetsmarknadsprövningen i dess helhet, vilket var fallet med LO, indikerade deras kommentarer att behovsprövningen borde kvarstå, om än i andra former. ${ }^{189}$

En mer liberal hållning återfinns i SACO:s remissvar. I de utgångspunkter som organisationen presenterade fastslogs att det är nödvändigt att säkerställa en större öppenhet gällande invandring från tredje land, i synnerhet rörande kvalificerad arbetskraft. Dessutom efterfrågade SACO en större öppenhet vad det gäller definitionen av det yrke som arbetstillståndet ska knytas till - en mer flexibel lösning skulle, enligt organisationen, kunna vara att koppla tillståndet till branschspecifik kompetens. När det gäller avskaffandet av arbetsmarknadsprövningen hade organisationen inte heller några principiella invändningar. Dock påpekades att arbetstagarorganisationernas roll i processen bör säkerställas och tydliggö-

\footnotetext{
${ }^{188}$ Ju2007/6628/EMA (LO).

${ }^{189}$ Ju2007/6628/EMA (TCO).
} 
ras. ${ }^{190}$ SACO:s principiella inställning delas även av Sveriges Ingenjörer, som är ett av organisationens medlemsförbund. Organisationen är principiellt för en öppen arbetsmarknad och emot inskränkningar av arbetskraftens rörlighet och har sedan länge sett som sin främsta roll att se till att arbetskraftsinvandringen inte leder till direkt lönedumpning eller försämring av anställningsvillkor. Dock är förbundet mycket angeläget om att inte få en myndighetsroll, utan anser att granskningen i övrigt ska skötas av ansvarig myndighet, d.v.s. Migrationsverket. ${ }^{191}$

Huvudorganisationen på arbetsgivarsidan, Svenskt Näringsliv, anser att de viktigaste egenskaperna i ett regelverk rörande arbetskraftsinvandring bör vara tydlighet och flexibilitet. Eftersom Sverige är ett litet och i hög grad internationellt beroende land är det även viktigt att systemet för arbetskraftsinvandring är öppet. Enligt Svenskt Näringsliv är det även nödvändigt att Sverige på ett aktivt sätt möter en globaliserad värld där nationalitet spelar en allt mindre roll för affärsrelationer och kontakter. Dessutom anser organisationen att arbetskraftsinvandringen har en viktig roll att fylla för att möta de demografiska utmaningar som man inom Sverige och den övriga industrialiserade världen står inför. Att Sverige blir ett attraktivt land är något som är nödvändigt om man ska gå segrande ur "the war for talent". I linje med dessa resonemang tillstyrkte organisationen också förslaget om avskaffandet av den myndighetsbaserade arbetsmarknadsprövningen. Vidare kritiserade man kopplingen av arbetstillstånden till en viss arbetsgivare och ett särskilt yrke, vilket ansågs hämma rörligheten på arbetsmarknaden. ${ }^{192}$

Sammanfattningsvis kan sägas att de organisationer, Sveriges Ingenjörer/SACO och Svenskt Näringsliv, som berörs av arbetskraftsinvandring av högkvalificerad arbetskraft, i det här fallet ingenjörer, båda förespråkar en svagt reglerad marknad, medan de som företräder mindre kvalificerad arbetskraft, i synnerhet LO, önskar betydligt starkare reglering.

\subsection{Invandring och rekrytering av ingenjörer från tredje land}

\subsubsection{Arbetskraftsinvandring till Sverige från tredje land ${ }^{193}$}

Det totala antalet personer från tredje land som beviljats uppehållstillstånd i Sverige av arbetsmarknadsskäl under de senaste åren presenteras i Tabell 8. Siffrorna visar på en tydlig uppgång under de senaste åren med en särskilt kraftig utveckling mellan 2006 och 2009. I statistiken ingår dock för 2008 och 2009 en stor grupp säsongsanställda. För att kunna

\footnotetext{
${ }^{190} \mathrm{Ju} / 2007 / 6628 / \mathrm{EMA}$ (SACO).

${ }^{191}$ Intervju - Sveriges Ingenjörer.

192 Ju/2007/6628/EMA (Svenskt Näringsliv), Intervju - Svenskt Näringsliv.

${ }^{193}$ Statistiken för 2009 är än så länge preliminär. Officiella uppgifter publiceras i februari 2010.
} 
jämföra statistiken med tidigare år har de som tidigare räknades som säsongsanställda, och därför inte ingick i statistiken, borträknats. De utgör den enskilt största gruppen arbetstagare, och är bärplockare från företrädelsevis Thailand. Även om dessa borträknas är det emellertid tydligt att det sker en viss ökning mellan 2008 och 2009, den dåliga konjunkturen till trots. Ökningen kan antas bero på förändringen av regelverket.

Tabell 8. Beviljade förstagångstillstånd av arbetsmarknadsskäl för tredjelandsmedborgare

\begin{tabular}{lrrrrr}
\hline År & 2005 & 2006 & 2007 & 2008 & 2009 \\
\hline Antal tillstånd & 5865 & 6094 & 9859 & $14513^{\star}(11513)$ & $17955^{\star}(11955)$ \\
\hline
\end{tabular}

* Säsongsanställda ingår (siffran inom parantes är en uppskattning av antalet utan säsonsanställda)

Källa: Migrationsverket

\subsubsection{Invandring av ingenjörer från tredje land}

I Figur 5 presenteras antalet arbetstillstånd för ingenjörer under tidsperioden 1994-2009. Även denna utveckling visar en tydlig uppgång efter 2006, vartefter antalet arbetstillstånd som beviljats till ingenjörer har flerdubblats. Jämfört med det totala antalet uppehållstillstånd för arbete som beviljats för tredjelandsmedborgare har andelen ingenjörer ökat under de senaste åren, från 7,8 \% 2007, över $11 \% 2008$, till.8,7 \% 2009. ${ }^{194}$ Det finns med andra ord fog för Migrationsverkets uppfattning att den typiska arbetskraftsinvandraren, förutom säsongsanställda, är en IT-specialist från Indien som arbetar i Stockholm. ${ }^{195}$ Statistik rörande fördelningen utefter olika yrkeskategorier finns endast för de senaste åren och tyvärr är denna bristfällig. Räknas de olika civilingenjörskategorierna samman kan dock en uppskattning göras över hur kvalifikationsgraden hos de som får arbetstillstånd utvecklas. Under 2007 beviljades 769 tillstånd för olika kategorier av ingenjörer och civilingenjörer. Av dessa uppgavs 174 vara civilingenjörer, vilket motsvarar ca $23 \%$. 2008 var det 446 civilingenjörer av totalt 1272 utfärdade tillstånd, motsvarande ca 35 \%. År 2009 beviljades 502 civilingenjörer tillstånd, av total 1044 beviljade tillstånd, vilket ger en andel om ca $48 \%$. Det tycks, med viss reservation för att beräkningen grundar sig på uppgivena yrkesbeteckningar, som om kvalifikationsgraden är tydligt ökande.

Att såväl antalet ingenjörer som beviljats tillstånd, som andelen ingenjörer, sjunker är förmodligen konjunkturrelaterat, men intressant är dock att nedgången är jämförelsevis liten. Siffrorna för 2009 ligger fortfarande betydligt över antalet som beviljades tillstånd 2007, trots att detta år i Sverige var högkonjunktur, och vi kan därför anta att liberaliseringen av reglerna kring arbetskraftsinvandringen bidragit till att hålla uppe antalet trots den dåliga konjunkturen.

\footnotetext{
${ }^{194}$ För jämförbarhet är procentsatsen beräknad på tptalt beviljade tillstånd utan säsongsanställda.

${ }^{195}$ Migrationsverket (2009) s. 6.
} 


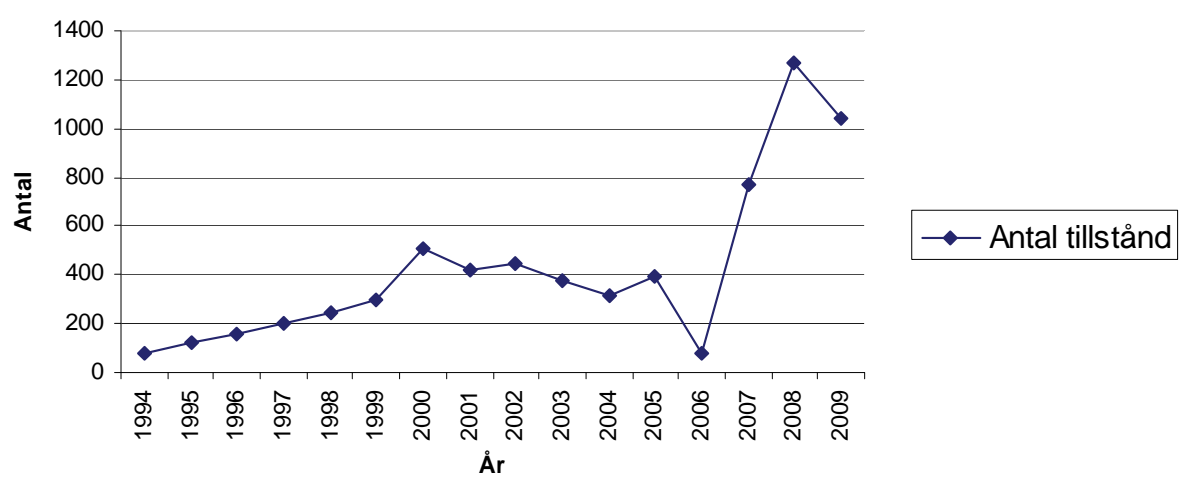

Källa: Migrationsverket

Figur 5. Beviljade arbetstillstånd för ingenjörer från tredje land 1994-2009

\subsubsection{Invandrade ingenjörers ursprung}

Det finns dock stora skillnader när det gäller ursprunget för de ingenjörer från tredje land som invandrat till Sverige under de senaste årtiondena och skillnaderna mellan olika regioner och länder har dessutom ökat. Fram till och med 2003 är det Europa och Asien som är de två största världsdelarna vad gäller arbetstillstånd för ingenjörer från tredje land. Europas andel minskar därefter, men detta beror förmodligen på den stora utvidgningen av EU, då ett antal länder gick från att vara tredje land till medlemsstater. Den mest anmärkningsvärda förändringen är annars den kraftiga numerära ökningen för asiatiska arbetstagare från 2007 och framåt.

I Tabell 9 redovisas utvecklingen 1994-2009 för de länder varifrån flest ingenjörer invandrat till Sverige 2009 visas de tio största ursprungsländerna för ingenjörer från tredje land som beviljats arbetstillstånd. Här syns tydligt att det stora asiatiska uppsvinget främst rör Kina och Indien, men att även andra asiatiska länder som Malaysia och Singapore ökat kraftigt under 2009. Även om de asiatiska länderna dominerar återfinns länder som USA och Australien och Kanada bland de länder varifrån flest ingenjörer invandrar till Sverige. De stora skillnaderna mellan dessa länder och de stora asiatiska ursprungsländerna Indien och Kina indikerar att det finns flera olika orsaker bakom beslutet att som ingenjör söka sig till Sverige. 
Tabell 9. Beviljade arbetstillstånd för ingenjörer från tredje land 1994-2009 efter de tio största länderna 2009

\begin{tabular}{|c|c|c|c|c|c|c|c|c|c|c|c|c|c|c|c|c|}
\hline Land/År & ஓ్ & 욕 & $\stackrel{\circ}{\stackrel{్}{-}}$ & §ิ & $\stackrel{\infty}{\stackrel{్}{్}}$ & ஓ & ઠ̊ํ․ & ¿্் & ণั่ & ஜ్̊․ & ర্ & 오ํ & ஜ & ڤ્̀ & : & : \\
\hline Kina & 4 & 23 & 8 & 20 & 16 & 9 & 44 & 45 & 30 & 34 & 40 & 59 & 3 & 166 & 318 & 232 \\
\hline Indien & 1 & 11 & 22 & 11 & 18 & 21 & 25 & 25 & 38 & 59 & 26 & 50 & 9 & 152 & 319 & 320 \\
\hline Malaysia & & & 2 & 3 & 8 & 4 & 11 & 7 & 9 & 5 & 1 & 1 & & 6 & 5 & 62 \\
\hline Singapore & & 2 & & & 13 & 12 & 4 & 1 & 3 & 1 & & & 3 & 6 & 14 & 48 \\
\hline USA & 49 & 15 & 31 & 45 & 31 & 49 & 70 & 50 & 41 & 33 & 23 & 38 & 12 & 77 & 103 & 45 \\
\hline Kroatien & - & 5 & 4 & 9 & 9 & 6 & 9 & 6 & 10 & 13 & 12 & 29 & 3 & 61 & 33 & 34 \\
\hline Japan & 10 & 15 & 19 & 24 & 25 & 30 & 33 & 31 & 20 & 24 & 31 & 44 & 9 & 38 & 66 & 32 \\
\hline Ryssland & - & 3 & 5 & 7 & 6 & 10 & 20 & 36 & 26 & 21 & 18 & 12 & 6 & 27 & 40 & 32 \\
\hline Australien & 4 & 7 & 9 & 5 & 11 & 10 & 22 & 22 & 25 & 25 & 14 & 15 & 6 & 32 & 49 & 30 \\
\hline Kanada & 4 & 8 & 15 & 18 & 15 & 21 & 28 & 12 & 28 & 7 & 11 & 12 & 3 & 20 & 27 & 25 \\
\hline
\end{tabular}

Källa: Migrationsverket

\subsubsection{Den nya lagstiftningen}

Den 15 december 2008 införde Sverige nya regler för arbetskraftsinvandring. Det statistiska underlaget för en analys av lagstiftningens betydelse för arbetskraftsinvandringen är bristfälligt, beroende på den korta tid som gått sedan reformen, kombinerad med den ekonomiska lågkonjunktur som sammanfallit med reformens genomförande. Statistik finns dock för 2009. Materialet redovisar de arbetsmarknadsärenden (exklusive ansökningar som rör artister, idrottsutövare, gästforskare och egna företagare) som avgjorts inom ramen för den nya lagstiftningen och innehåller således nya kategorier, exempelvis arbetstagare som tidigare varit asylsökande.

När det gäller de nya regler som tillåter tidigare asylsökande att söka om arbetstillstånd beviljades endast 452 ansökningar, vilket utgör ca $3 \%$ av det totala antalet beviljade tillstånd som är inkluderade i det presenterade materialet. En anledning till att det är relativt få tidigare asylsökande som fått avslag som sökt tillstånd för arbete kan vara att för att få arbetstillstånd krävs ett giltigt pass, något som många asylsökande saknar.

I en av Migrationsverkets rapporter till regeringen avseende arbetet med de nya reglerna berörs även handläggningstiden. Enligt verkets egna siffror har den genomsnittliga totala handläggningstiden varit 29 dagar och $97 \%$ av ansökningarna hade avgjorts inom tre månader. Det fanns dock en betydande skillnad i handläggningstid mellan de ansökningar som skickats in elektroniskt jämfört med dem som inkommit i pappersform och verket har därför som ambition att ökad andelen elektroniska ansökningar och förenkla processen. Ytterligare en faktor som förlänger handläggningstiden är om Migrationsverket i efterhand tvingas inhämta uppgifter om villkoren för den anställning som ligger till grund för ansökan. I de fall (ca 15 \% av ansökningarna) verket begärt in yttranden från berörda arbetsmarknadsorganisationer har tiden förlängts med i genomsnitt 20 dagar. ${ }^{196}$

\footnotetext{
${ }^{196}$ Migrationsverket (2009).
} 
När det gäller arbetsmarknadsparternas syn på utfallet av den nya lagstiftningen finns det vissa skillnader. Svenskt Näringslivs uppfattning är att det nya systemet har fungerat relativt väl, även om det finns ytterligare åtgärder som skulle kunna bidra till en mer omfattande arbetskraftsinvandring. Eftersom antalet som invandrat till Sverige från tredje land i syfte att arbeta är relativt litet menar organisationen att det även krävs andra åtgärder, exempelvis en mer aktiv marknadsföring av Sverige utomlands. ${ }^{197}$ Från arbetstagarhåll är man mer kritisk. Även om Sveriges Ingenjörer ser det som sin uppgift att bevaka kollektivavtalens efterföljande betraktar organisationen den "myndighetsroll" som det nya regelverket tilldelat berörda fackförbund som problematisk. I och med att Arbetsförmedlingen kopplats bort från tillståndsprocessen har arbetstagarorganisationerna fått lägga alltmer tid på att kontrollera löne- och anställningsvillkor vid rekrytering av arbetskraft från tredje land, vilket är ett resurskrävande arbete. ${ }^{198}$

\subsubsection{Rekrytering av arbetskraft från tredje land}

Arbetsförmedlingens inblandning i rekryteringen av utländsk arbetskraft till Sverige är framförallt inriktad på det arbete som bedrivs inom ramen för EURES-samarbetet på europeisk nivå. Kärnan i detta arbete är de så kallade EURES-rådgivarna, vilka tillhandahåller information, ger vägledning och förmedlar arbeten inom Europa. Bortsätt från att arbetsförmedlingen medverkar vid rekrytering av enskilda anställda deltar de även i speciella rekryteringsdagar i olika medlemsländer. Dock är detta arbete i huvudsak begränsat till EU/EES-området, då Arbetsförmedlingen inte har något uppdrag att förmedla arbete till sökande utanför EU/EES och det inte finns något upparbetat nätverk i de länder som ligger utanför denna region. ${ }^{199}$

Några direkta rekryteringsinitiativ från officiellt svenskt håll finns inte, motsvarande det danska. Ett initiativ kan dock sägas ha tagits i och med att ett arbetsmarknadsråd i Peking utsågs 2009. Förutom detta finns också ett svenskt arbetsmarknadsråd i Bryssel. Tidigare fanns också arbetsmarknadsråd i Berlin och Washington, men dessa avskaffades 2005. Till arbetsmarknadsrådets uppgifter hör potentiell arbetskraftsmigration och att undersöka var kompetens finns, med arbetsmarknadsministerns ord " proaktivt arbete för att locka intresserade kvalificerade arbetstagare till Sverige. Det kan ske genom kontakter och utbyte med universitet och forskarmiljöer, lokalt informationsarbete, deltagande på olika mässor m.m”. ${ }^{200}$ I detta samband nämndes särskilt ingenjörer. Eftersom tjänstetillsättningen inföll vid samma tidpunkt som den ekonomiska krisen har detta inte fått någon större omfattning. Samtidigt poängteras också att en

\footnotetext{
${ }^{197}$ Intervju - Svensk Näringsliv.

${ }^{198}$ Intervju - Sveriges Ingenjörer.

${ }^{199}$ Intervju - Arbetsförmedlingen.

${ }^{200}$ Littorin, S-O. (2008)
} 
rekrytering av kinesiska ingenjörer inte alltid är problemfri då det finns brister i utbildningssystemet och det kan vara svårt för svenska företag att få tag på kinesisk arbetskraft som passar in i organisationen, både i Kina och i andra länder. Här har SKF skapat ett program för att komma tillrätta med både risken för att de kinesiska arbetstagarna snabbt byter arbetsgivare (så kallad job hopping) och den upplevda bristen på soft skills. Programmet går ut på att man rekryterar kinesiska studenter som läser vid europeiska universitet, kontrakterar dessa och låter dem först arbeta på något europeiskt dotterbolag $\mathrm{i}$ två år efter examen innan de anställs vid koncernens kinesiska dotterbolag. ${ }^{201}$

Att Sverige inte har några officiella rekryteringskontor kan förklaras av att det svenska näringslivet domineras av mycket stora företag, vilka sköter sitt eget rekryteringsbehov av utländsk arbetskraft via sina lokala bolag i det aktuella landet. För Ericssons del sker till exempel rekryteringen genom att personer anställs via företagets lokalkontor, t ex i Gurgaon, Indien. Ericsson har i dagsläget (2009) cirka 4000 anställda på 24 kontor inom sitt asiatiska affärsområde. Från dessa lokalkontor kan de senare rekryteras till tjänster och uppdrag utomlands, till exempel i Sverige. ${ }^{202}$

För små och medelstora företag kan detta innebära att det inte finns så många kanaler. Som ett led i förändringen av regelverket för arbetskraftsinvandring fick Svenska institutet, som är en myndighet vars huvudsakliga uppgift är att främja intresset för Sverige utomlands och stödja relationer med andra länder, uppdraget att samordna arbetet med att marknadsföra Sverige hos utländska arbetssökande. ${ }^{203}$ Inför budgetåret 2009 tilldelades även institutet särskilda medel för at skapa en internetbaserad informationssida för arbetssökande tredjelandsmedborgare och samordna informationsarbetet på detta område. ${ }^{204}$ Under rubriken "Working in Sweden" på Svenska institutets webbplats finns information som är riktad till tredjelandsmedborgare. Här beskrivs hur man söker arbetstillstånd i Sverige och det finns länkar till EURES-portalen, samt en lista över de bristyrken, för vilka ett förenklat tillståndsförfarande tillämpas. ${ }^{205}$ Denna webbplats är dock inriktad på att individer själva söker jobb. I länder som Kina kan det institutionella ramverket stå i konflikt med ett sådan förfarande, då arbetsförmedling där huvudsakligen sker via agenturer. För stora företag med egna dotterbolag innebär detta inget problem, men för mindre företag och enskilda arbetssökande kan det vara problematiskt. ${ }^{206}$

Deltagandet i rekryteringsinitiativ har varit begränsat även från arbetsmarknadens parters sida. Sveriges Ingenjörer har inte varit involverade i konkret rekrytering på central nivå och arbetet med arbetskraftsinvandring är begränsat till att förmedla information och ge rekommenda-

${ }^{201}$ Intervju Oscar Berger 2009-12-19.

${ }^{202}$ Intervju Ericsson Press Office 2009-12-10.

${ }^{203}$ SFS 2007:1224, 2 §.

${ }^{204}$ Regeringsbeslut 2008-12-18.

${ }^{205}$ www.sweden.se.

${ }^{206}$ Intervju Oscar Berger 2009-12-19. 
tioner till Migrationsverket vid behandling av enskilda ärenden. ${ }^{207}$ Inte heller Svenskt Näringsliv, eller någon av organisationens medlemsföretag, har varit direkt involverad i rekrytering av arbetskraft utomlands. Organisationens inblandning i frågor som rör detta område är snarare begränsat till att ge information om gällande regelverk och bidra med stöd i speciella fall som är av principiell natur. ${ }^{208}$

Det mesta tyder på att det huvudsakliga arbetet med att rekrytera arbetskraft från tredje land sker på företagsnivå. Såväl Sveriges Ingenjörer som Svenskt Näringsliv ser också detta som det naturliga arbetssättet. ${ }^{209}$ För fackförbundshåll betraktar man även rekryteringen av arbetskraft från utlandet som en del i företagens globaliseringsprocess, där omflyttning av personal mellan företagets olika delar är ett naturligt inslag, snarare än ett resultat av brist inom vissa yrkeskategorier. ${ }^{210}$ Denna bild stöds även av dem som arbetar med rekrytering av utländsk arbetskraft på arbetsförmedlingen, vilka uppfattar det som att många arbetsgivare har bestämt sig att de vill ha personal från en viss region och rekryterar därefter. ${ }^{211}$ Enligt arbetsmarknadens parter spelar även specialiserade rekryteringsföretag en viss roll vid rekrytering av arbetskraft utomlands. Några formella och återkommande kontakter med dessa finns dock inte på arbetstagar- eller arbetsgivarsidan. ${ }^{212}$

Såväl myndigheter som arbetsmarknadens parter påpekar även att rekryteringen av arbetskraft från utlandet kantas av en rad problem. Från Arbetsförmedlingens sida nämns bristande språkkunskaper, vissa svårigheter att validera kunskaper/examina, samt ett bristande förberedelsearbete från arbetsgivares sida, som de mest framträdande problemen. Ett exempel på det sistnämnda är att många utländska arbetstagare har dåliga kunskaper om det svenska trygghetssystemet, vilket kan medföra stora problem vid arbetslöshet etc. Det bästa sättet att lösa problemen sades vara att förmedla information i dessa frågor, vilket Arbetsförmedlingen arbetar aktivt med. ${ }^{213}$ Även Svenskt Näringsliv ser språket som ett av de problem som finns när det gäller att locka utländsk arbetskraft till Sverige - även om engelska ofta är arbetsspråket för högkvalificerad arbetskraft är svenskan viktig för det sociala livet. När de gäller högkvalificerad arbetskraft menar Svenskt Näringsliv att det svenska skattesystemet motverkar arbetskraftsinvandring, vilket kan påverka landet negativt i en eventuell framtida kamp om högutbildad arbetskraft. ${ }^{214}$

\footnotetext{
${ }^{207}$ Intervju - Sveriges Ingenjörer.

${ }^{208}$ Intervju - Svenskt Näringsliv.

${ }^{209}$ Intervjuer - Sveriges Ingenjörer och Svenskt Näringsliv.

${ }^{210}$ Intervju Sveriges Ingenjörer.

${ }^{211}$ Intervju - Arbetsförmedlingen.

${ }^{212}$ Intervjuer - Sveriges Ingenjörer och Svenskt Näringsliv.

${ }^{213}$ Intervju - Arbetsförmedlingen.

${ }^{214}$ Intervju - Svenskt Näringsliv.
} 


\subsubsection{Framtida behov av ingenjörer}

Den svenska industrin utmärks av en hög koncentrationsgrad när det gäller företagsstrukturen. Ett fåtal stora företag har stått för en relativt stor del av den totala produktionen under 1900-talet, och flertalet av dessa är grundade före eller strax efter sekelskiftet 1900. Jämförs storleksfördelningen av industriföretag mellan västeuropeiska länder, finner vi att Sverige har störst andel stora företag per invånare och också störst andel stora företag överlag. ${ }^{215}$

Traditionellt har det svenska näringslivet dominerats av en stor exportorienterad tillverkningsindustri, baserad på bland annat god tillgång på inhemska råvaror som järn och trä. Dels finns järn- och stålindustrin med anor från 1600-talets järnbruk. Svensk stålindustri består idag av specialiserade företag, av vilka många är världsledande. I Sverige finns också ett flertal stora trä- och pappersindustrier, såsom SCA och Stora Enso. Till dessa tillkommer verkstadsindustrin, som till stor del grundlades under det sena 1800-talet och tidiga 1900-talet och baserades på de så kallade snilleindustrierna, dvs. industrier som bygger på tekniska uppfinningar och innovationer. Exempel på företag som grundades under denna period är Ericsson (telefoner), Atlas Copco (borrar, gruvutrustning), AGA (gasfyrar) och SKF (kullager). Till dessa har kommit några senare storföretag, också de teknik- och innovationsbaserade, såsom Electrolux och biltillverkarna Volvo och Saab. Även dessa företag har ofta haft sin bas inom den äldre verkstadsindustrin. Volvo växte exempelvis fram som en del inom SKF, Saab skapades genom Bofors och Svenska Järnverksverkstäderna och Electrolux bildades ursprungligen som en del av AGA. Till dessa ska läggas ett fåtal nyare storföretag, inom bland annat handeln, som Tetrapak, H \& M och IKEA. ${ }^{216}$

Det svenska näringslivet, framför allt vad gäller tillverkningsindustri och tjänstesektor, består till stor del av verksamheter med högt kunskapsinnehåll. Michael Porter har hänfört detta till den sammanpressade lönestrukturen i Sverige, som gjort kvalificerad arbetskraft relativt billig och mindre kvalificerad dyr. Det svenska näringslivet är därför beroende av ett relativt stort antal välutbildade personer, inte minst ingenjörer. ${ }^{217} \mathrm{Jäm}$ fört med andra länder kan vi därför förvänta oss en relativt hög efterfrågan på ingenjörer.

Den goda arbetsmarknaden för ingenjörer i Sverige visare sig också i den låga arbetslösheten för yrkesgruppen. Sveriges Ingenjörer presenterar regelbundet statistik som baseras på uppgifter om hur stor andel av förbundets medlemmar som uppbär ersättning från arbetslöshetskassa. Dessa siffror visar att visar att andelen arbetslösa av Sveriges Ingenjörers medlemmar uppgick till ungefär 1,5 \% i augusti 2009, vilket dock var en tydlig ökning jämfört med samma tidpunk under föregående år då siffran

\footnotetext{
${ }^{215}$ Henrekson \& Jakobsson (2001).

${ }^{216}$ Magnusson (1997).

${ }^{217}$ Sölvell, Zander \& Porter (1999).
} 
låg under 1 \%. I jämförelse med 2004 års toppnotering på nära 3,5 \% ter sig denna nivå emellertid låg. Dessutom visar denna statistik att det finns tydliga skillnader mellan olika undergrupper, både mellan civil- och högskoleingenjörer och mellan olika inriktningar inom dessa båda grupper. Exempelvis var andelen av Sveriges Ingenjörers medlemmar som fick ersättning från arbetslöshetskassen under $1 \%$ för vissa civilingenjörsinriktningar och så hög som 3 \% för högskoleingenjörer med inriktning mot maskinteknik. ${ }^{218}$

Generellt sett kan efterfrågan på ingenjörer tillgodoses på två olika sätt, antingen genom inhemskt utbildade ingenjörer, eller genom utländskt utbildade ingenjörer. Den förstnämnda består av personer med hemvist i Sverige eller utländska studenter. Denna grupp kan antas vara den grupp som ur anställningssynpunkt medför lägst transaktionskostnader. Dock har ingenjörsutbildningarna vid landets högskolor har under flera år brottats med tomma platser. Från 2010 räknar högskoleverket med att bristen på civilingenjörer och ingenjörer på svensk arbetsmarknad kommer att uppgå till drygt 1000 personer per år, på grund av att för få påbörjar utbildningen. ${ }^{219}$ Enligt Statistiska centralbyråns (SCB) prognoser att kommer det dock att råda ett generellt överskott på civilingenjörer vid samma tidpunkt. Emellertid förutspår SCB brist på vissa typer av civilingenjörer och inom yrkesgruppen högskole- och gymnasieingenjörer, där det är ett stort underskott inom vissa inriktningar. ${ }^{220}$ Ökat antal sökande till högskoleutbildningar som ett resultat av den ekonomiska krisen kan dock påverka antalet examinerade ingenjörer i framtiden. Någon färsk sammanställning av statistik för vilka utbildningar som sökts under det senaste året saknas dock. Förslag som syftar till förlängda tekniska utbildningar på gymnasienivå kan även påverka balansen mellan tillgång och efterfrågan för vissa ingenjörsgrupper.

Den efterfrågan som inte kan täckas med inhemskt utbildade ingenjörer, eller där de inhemska ingenjörerna inte motsvarar de efterfrågade kvalifikationerna, kan täckas med ingenjörer från annat land, antingen från EU/EES-området eller från tredje land. Det finns naturligtvis även andra möjligheter, som att svenska ingenjörer fortsätter att arbeta efter uppnådd pensionsålder, men dessa kan inte antas täcka hela efterfrågan. I likhet med majoriteten av EU:s länder har Sverige också en demografisk utveckling i riktning mot en åldrande befolkning. Detta bör också leda till en ökad efterfrågan på kvalificerad arbetskraft från länder utanför EU, en efterfrågan som i ökande grad också kan mötas genom förenklat och liberaliserat regelverk för arbetskraftsinvandring.

När det gäller arbetskraftsinvandring som ett sätt att möta underskottet på ingenjörer menar arbetsmarknadens parter att invandring av personer med kompens inom det aktuella området kan ses som en del av lösningen.

\footnotetext{
${ }^{218}$ Sveriges Ingenjörer (2009).

${ }^{219}$ Högskoleverket (2008).

${ }^{220}$ Statistiska centralbyrån (2009).
} 
Från Svenskt Näringsliv påpekas att arbetskraftsinvandring är ett av flera sätt att möta behovet av ingenjörer på den svenska arbetsmarknaden, men att det bör ses som minst lika viktigt att svenska ingenjörer kan ges möjlighet att åka utomlands för att arbeta. ${ }^{221}$ Trots att man inom Sveriges Ingenjörer ser kopplingen mellan arbetskraftsinvandring och arbetsmarknaden för vissa yrkesgrupper i Sverige framhävs att mycket av den arbetskraftsinvandring som sker inte kan kopplas till direkta bristyrken utan till enskilda företags "globaliseringsprocess". 222 Arbetsförmedlingens arbete inom ramen för EURES-samarbetet, vilket har som ett delmål att sätta in speciella insatser när det gäller olika bristområden, har dock blottlagt problemet med att det kan uppstå konkurrens mellan olika EU-länder om den kvalificerade arbetskraften. ${ }^{223}$ En eventuell konkurrens mellan olika medlemsländer är även en fråga som diskuterats inom forskningen $^{224}$ och som kan påverka möjligheten att locka ingenjörer från tredje land till Sverige. Forskningen om arbetskraftens globala rörlighet ${ }^{225}$ visar också att förhållandena i mottagarländerna är en viktig faktor bakom flödet av människor mellan olika länder och regioner.

\subsection{Nationella utmaningar för rekryteringspolitiken}

\subsubsection{Reglering}

Den 15 december 2008 infördes en ny lagstiftning rörande arbetskraftsinvandring från tredje land till Sverige. Det nya regelverket medförde en förenkling av tillståndshanteringen för arbetskraftsinvandrare från tredje land genom att Migrationsverket inte längre skulle samråda med Arbetsförmedlingen före beslut. Dessutom innebar den nya lagstiftningen en tydlig liberalisering jämfört med tidigare bestämmelser, bland annat som ett resultat av att bedömningen om det finns behov av att rekrytera arbetskraft från tredje land fördes över till enskilda arbetsgivare och genom borttagandet av tidigare skrivelser som fokuserade på rådande brist som ett villkor för arbetstillstånd. Ytterligare en förändring var även öppnandet av möjligheten för asylsökande som fått avslag på sin ansökan att söka uppehållstillstånd för arbete utan att lämna Sverige, vilket var en rättighet som även utsträcktes till personer som fått tillstånd att resa till Sverige för att söka arbete inom yrken där ett stort behov av arbetskraft föreligger. Jämfört med tidigare lagstiftning innebär de nya reglerna också en förenkling, då vissa specialtillstånd, exempelvis för säsongsarbete, har tagits bort. Dessa ärenden ska numera hanteras inom den ordinarie tillståndsgivningen för tillfälligt uppehållstillstånd för arbete.

\footnotetext{
${ }^{221}$ Intervju - Svenskt Näringsliv.

${ }^{222}$ Intervju - Sveriges Ingenjörer.

${ }^{223}$ Intervju - Arbetsförmedlingen.

${ }^{224}$ Se t.ex. Castles (2006).

${ }^{225}$ Se t.ex. Freeman (2006).
} 


\subsubsection{Strategier}

En tydlig ambition bakom lagstiftningsförändringen var att göra det enklare för människor från tredje land att komma till Sverige för att arbeta. Skapandet av ett effektivare och mer flexibelt system för arbetskraftsinvandring i syfte att underlätta rekrytering från tredje land var även viktig del i regeringens motivering för de genomförda förändringarna. Dock verkar de svenska myndigheterna inte har vidtagit några direkta rekryteringsåtgärder med särskild inriktning på kvalificerad arbetskraft från tredje land. Arbetsföremedlingen arbetar aktivt med förmedling av arbete inom EU/EES-området, men när det gäller arbetstagare från tredje land finns ingen liknande åtgärder. Svenska institutet har dock ålagts ansvaret för att samordna arbetet med att marknadsföra Sverige gentemot utländska arbetssökande och inför budgetåret 2009 tilldelades institutet medel specifikt för detta ändamål. På institutets hemsida finns också information som är riktad speciellt till tredjelandsmedborgare som vill arbeta $\mathrm{i}$ Sverige. Arbetsmarknadens parter har inte heller varit direkt involverade i rekrytering av arbetskraft från tredje land. Dylika aktiviteter verkar i stället vara något som hanteras på företagsnivån, antingen genom direkt rekrytering eller via speciella konsultföretag.

\subsubsection{Utveckling}

Även om det står klart att arbetskraftsinvandring från tredje land, generellt såväl som när det gäller ingenjörer, har ökat under de senaste åren är det svårt att uttala sig om vilken inverkan de senaste lagstiftningsförändringarna har haft. Det nya regelverket rörande arbetskraftsinvandring till Sverige infördes för lite över ett år sedan och det är alltför tidigt för att bedöma vilken varaktig inverkan lagstiftningen har haft på arbetskraftsinvandringen från tredje land. Även om det finns statistik att tillgå är det är svårt att uttala sig om konkreta effekter då införandet av de nya reglerna sammanföll med en lågkonjunktur. Dock tycks det som om regelverket haft viss effekt. När det gäller handläggningen är den genomsnittliga tiden 29 dagar och Migrationsverket arbetar aktivt med att öka andelen elektroniska ansökningar, vilket har stor effekt på handläggningstiden. Uppfattningen på arbetsgivarsidan är också att den nya lagstiftningen fungerar bra och att denna bör ses som en positiv förändring. Vissa arbetstagarorganisationer ställer sig dock kritiska till att de fått ta på sig en "myndighetsroll" i den kontrollprocess som genomförs i samband med tillståndsgivningen. Vidare är det uppenbart att det finns flera faktorer som motverkar en större arbetskraftsinvandring. För det första är språket ett problem. Trots att utländsk arbetskraft som arbetar inom högkvalificerade områden inte nödvändigtvis begränsas i det konkreta arbetet kan bristande kunskaper i det svenska språket påverka den sociala situationen. Vidare finns det problem som kan kopplas till det svenska trygghetssystemet, då många invandrare inte känner till vilka rättigheter och 
skyldigheter de har. Från arbetsgivarhåll lyfter man dessutom fram det höga skattetrycket som exempel på en negativ faktor när det gäller invandring av högkvalificerad arbetskraft. Därtill framhålls att det borde göras mer för att marknadsföra Sverige utomlands i syfte att locka utländsk arbetskraft till landet. När det gäller behovet av ingenjörer tyder aktuella prognoser på att det alltjämt kommer att finnas ett stort underskott på kvalificerad arbetskraft inom vissa områden och branscher. Dock kan den senaste ökningen av antalet ansökningar till högskoleutbildningar, tillsammans med föreslagna förändringar av utbildningen på gymnasienivå, möjligen bidra till att minska denna brist på utbildade ingenjörer. Det är även troligt att arbetskraftsinvandring kan komma att spela en viss roll för att möte behovet av personal i svenska företag.

\section{Referenser}

Betänkande 2002/03:SFU8, Socialförsäkringsutskottets betänkande - Migration och asylpolitik.

Betänkande 2008/2009:SfU3, Socialförsäkringsutskottets betänkande - Nya regler för arbetskraftsinvandring.

Castles (2006), ”Back to the Future? Can Europe meet its Labour Needs through Temporary Migration?” Oxford: IMI Working Paper No. 1.

Direktiv 2009/50/EG, av den 25 maj 2009, om villkor för tredjelandsmedborgares inresa och vistelse för högkvalificerad anställning.

Dir 2004:21, Kommittédirektiv - Översyn av regelverket för arbetskraftsinvandring.

Dir 2009:53, Kommittédirektiv - Cirkulär migration och utveckling.

Ds 2007:27, Ett effektivt och flexibelt system för arbetskraftsinvandring.

Ekot, Sveriges Radio Alliansen enig om arbetskraftsinvandring 2006-10-11.

Freeman (2006), "People Flows in Globalization", i The Journal of Economic Perspectives, vol. 20, nr. 2. S. 145-170.

Henrekson \& Jakobsson (2001), ”The Transformation of Ownership Policy and Structure in Sweden: Convergence towards the Anglo-Saxon Model?” Konferenspapper "Small States in World Markets - Fifteen Years Later". Göteborg 27-29 september 2001.

Högskoleverket (2008), ”Högskoleutbildningarna och arbetsmarknaden. Ett planeringsunderlag inför läsåret 2008/09”. Rapport 2008:2 R.

Intervju - Arbetsförmedlingen, Dieter Zippert (EURES-rådgivare).
Intervju - Arbetsmarknadsråd Oscar Berger 2009-12-19.

Intervju - Ericsson Press Office 2009-12-10.

Intervju - Svenskt Näringsliv, Karin Ekenger (ansvarig för arbetskraftsinvandring) 2009-10-19.

Intervju - Sveriges Ingenjörer, Magnus Skagerfält (utredare utvecklingsenheten) 2009-10-12.

Ju/2007/6628/EMA, Remissvar.

Littorin, S-O. (2008) Svenska regeringen jagar spetskompetens i Kina, ”Dagens Nyheter 2008-06-15.

Magnusson (1997), ”Sveriges ekonomiska historia”, Stockholm: Prisma.

Migrationsverket (2009), "Redovisning av arbetet med nya regler för arbetskraftsinvandring” (http://www.migrationsverket.se/download/18.adab6481250c08aec9 80002491/112-2009-19600_inkl_ bilagor.pdf.

Migrationsverket (2009) Delårsrapport.

Motion 2007/2008:Sf27, av Kalle Larsson m.fl. (v).

Motion 2007/2008:Sf28, av Veronica Palm m.fl. (s).

Proposition 2007/2008:147, Nya regler för arbetskraftsinvandring.

Regeringsbeslut 2008-12-18, Regleringsbrev för budgetåret 2009 avseende Svenska institutet.

Riksdagens snabbprotokoll 2002/03:109 2003-05-22.

SFS 2005:716, Utlänningslagen.

SFS 2007:1224, Förordning med instruktion för Svenska institutet.

SFS 2008:884, Lag om ändring i utlänningslagen (2005:716). 
SFS 2008:895, Förordning om ändring i utlänningsförordningen (2006:97).

SOU 2005:50, ”Arbetskraftsinvandring till Sverige - befolkningsutveckling, arbetsmarknad i förändring, internationell utblick".

SOU 2006:87, "Arbetskraftsinvandring till Sverige - förslag och konsekvenser" Statistiska centralbyrån (2009), Trender och prognoser 2008 - befolkningen, ut- bildningen, arbetsmarknaden med sikte på 2030.

Sveriges Ingenjörer (2009), Arbetsmarknadsinformation - Augusti 2009.

Sölvell, Zander \& Porter (1999), ”Advantage Sweden”. Stockholm: Norstedts juridik. www.sweden.se, Svenska institutets informationssida på Internet. 


\title{
7. Nordiske udfordringer i arbejdsindvandringspolitikken for kvalificeret arbejdskraft
}

\author{
Nana Wesley Hansen og Søren Kaj Andersen
}

I de forudgående kapitler er de sidste 10 års arbejdsindvandringspolitik for kvalificeret arbejdskraft fra tredjelande blevet gennemgået i forhold til Danmark, Sverige, Norge, Finland og Island med særlig henblik på rekruttering af ingeniører. I dette afsluttende kapitel vender vi os nu mod den komparative analyse. De vigtigste ligheder og forskelle mellem de nordiske lande analyseres i forhold til både regler, strategi og realiteter i rekrutteringen af kvalificeret arbejdskraft fra tredjelande til Norden. Udgangspunktet er således de gældende regler. Strategi omhandler institutioner og andre typer af initiativer, der er bygget op i relation til reguleringen og realiteterne af den faktiske indvandring af højtkvalificeret arbejdskraft fra tredjelande. For hvert afsnit peges der afslutningsvis på særlige udfordringer for arbejdsindvandringspolitikken i de nordiske lande, og koordinerings- og samarbejdsmuligheder mellem de nordiske lande diskuteres. Endelig er der tilføjet et afsnit, der diskuterer andre perspektiver på arbejdsindvandringspolitik, som ikke direkte vedrører regler eller politisk strategi. Samlet kan dette kapitel forhåbentligt danne baggrund for videre diskussion om behovet for rekruttering af arbejdskraft fra tredjelande til Norden og måden, hvorpå rekrutteringen kan blive et positivt bidrag til de nationale arbejdsmarkeder.

\subsection{Regler}

Reglerne for opholds- og arbejdstilladelse i de forskellige nordiske lande for kvalificeret arbejdskraft fra tredjelande har mange fællestræk. ${ }^{226}$ Samtlige landes lovgivning balancerer mellem 1) at facilitere arbejdsgiveres efterspørgsel efter arbejdskraft og 2) at beskytte det nationale og europæiske arbejdsmarked mod dumping af løn og arbejdsvilkår. Man

\footnotetext{
${ }^{226}$ Ministeriet for Flygtninge, Indvandrere og Integration, Erhvervsenheden (2009), Faktuel rapport om de nordiske landes udlændingeretlige regler vedrørende arbejdskraftsindvandring med fokus på højt kvalificeret udenlandsk arbejdskraft, udarbejdet af arbejdsgruppen om arbejdskraftsindvandring for Den Nordiske Samrådsgruppe på Højt Niveau for Flygtningespørgsmål. 10. juni 2009
} 
kan således sige, at alle landene bedriver en eller anden form for kontrolleret åbning af egne arbejdsmarkeder i forhold til international arbejdskraft. ${ }^{227}$ Forskellene derimod ligger i, hvordan man sikrer brug af den nationale arbejdskraft eller arbejdskraft fra EU/EØS, hvorvidt adgang gives til et særskilt job, en branche eller til hele arbejdsmarkedet på én gang og i forståelsen af, hvad kvalificeret arbejdskraft er.

Oversigtsboks: Forskelle i metode til at kontrollere åbning af de nationale arbejdsmarkeder i Norden for arbejdskraft fra tredjelande

\begin{tabular}{|c|c|c|c|}
\hline Land & $\begin{array}{l}\text { Sikring af beskæftigelsen for } \\
\text { national/EU/EøS-arbejdskraft }\end{array}$ & $\begin{array}{l}\text { Afgrænsning af adgang til } \\
\text { arbejdsmarkedet }\end{array}$ & $\begin{array}{l}\text { Afgrænsning af gruppe, som } \\
\text { kan få særlig nem adgang }\end{array}$ \\
\hline Danmark & $\begin{array}{l}\text { Administrativt via arbejds- } \\
\text { markedsbalancemodellen } \\
\text { Trepartsdrøftelser }\end{array}$ & $\begin{array}{l}\text { Adgang til konkret jobtilbud } \\
\text { Adgang til hele arbejds- } \\
\text { markedet som jobsøger }\end{array}$ & $\begin{array}{l}\text { Kvalificeret arbejdskraft - } \\
\text { bestemmes på baggrund } \\
\text { af efterspørgsel/fleksibel } \\
\text { justering af regler }\end{array}$ \\
\hline Sverige & $\begin{array}{l}\text { Arbejdsmarkedsprøvning } \\
\text { ved arbejdsgiver, som dog } \\
\text { skal sikre annoncering af } \\
\text { job nationalt og via Eures }\end{array}$ & Adgang til konkret jobtilbud & $\begin{array}{l}\text { Arbejdskraft - alt efter efter- } \\
\text { spørgsel fra arbejdsgiver }\end{array}$ \\
\hline Norge & $\begin{array}{l}\text { Arbejdsmarkedsprøvning } \\
\text { ved myndighed - dog } \\
\text { særlig kvote på } 5000 \\
\text { specialister/faglærte uden } \\
\text { arbejdsmarkedsprøvning }\end{array}$ & Adgang til konkret jobtilbud & $\begin{array}{l}\text { Kvalificeret arbejdskraft - } \\
\text { bestemmes på baggrund } \\
\text { af efterspørgsel/fleksibel } \\
\text { justering af regler }\end{array}$ \\
\hline Finland & $\begin{array}{l}\text { Til og med } 2010 \text { arbejds- } \\
\text { markedsprøvning ved } \\
\text { myndighed - undtaget } \\
\text { særlige grupper af speciali- } \\
\text { ster og ledere. Fra } 2011 \\
\text { forslag om arbejdsmarkeds- } \\
\text { prøvning ved arbejdsgiver. }\end{array}$ & $\begin{array}{l}\text { Adgang til konkret jobtilbud } \\
\text { Adgang til at skifte job } \\
\text { inden for samme branche }\end{array}$ & $\begin{array}{l}\text { Frem til og med } 2010 \text { lettere } \\
\text { adgang for få særlige grup- } \\
\text { per. Fra } 2011 \text { forslag om } \\
\text { samme adgang for arbejds- } \\
\text { kraft - alt efter efterspørgsel } \\
\text { fra arbejdsgiver. }\end{array}$ \\
\hline Island & $\begin{array}{l}\text { Arbejdsmarkedsprøvning } \\
\text { ved myndighed og } \\
\text { fagforeninger }\end{array}$ & $\begin{array}{l}\text { Adgang til konkret jobtilbud - } \\
\text { kun ved afgrænset opgave }\end{array}$ & $\begin{array}{l}\text { Lettere adgang for få særlige } \\
\text { grupper af specialister }\end{array}$ \\
\hline
\end{tabular}

Alle de nordiske landes regelværk efterkommer det grundlæggende princip, at den udenlandske arbejdskraft udelukkende skal supplere den nationale eller EU/EØS-arbejdskraften, når der er behov for det. I Norge, Finland, Island og Sverige har man til at sikre dette egentlig arbejdsmarkedsprøvning, der dels består i, at man inden der rekrutteres arbejdskraft fra tredjeland sikrer, at den relevante nationale eller EU/EØS-arbejdskraft ikke er tilgængelig og dels at løn og arbejdsvilkår svarer til nationale forhold. I den forbindelse høres ofte arbejdsmarkedsorganisationerne. I Norge er der tale om en myndighedsbaseret arbejdsmarkedsprøvning via arbejdsformidlingssystemerne. Den norske „fast track“-ordning for faglærte og specialister tillader dog en kvote på maksimalt 5000 rekrutteringer, hvor man ikke behøver at arbejdsmarkedsprøve. I Island skal alle ansøgninger arbejdsmarkedsprøves, og derudover høres også de faglige organisationer på det pågældende fagområde. I Sverige derimod er man gået helt bort fra den myndighedsbaserede arbejdsmarkedsprøvning i 2008, og i stedet er det nu arbejdsgivernes vurdering af rekrutteringsbe-

\footnotetext{
${ }^{227}$ Lowell (2005)
} 
hov, som ligger til grund for tildeling af opholds- og arbejdstilladelse. ${ }^{228}$ Finland har haft tradition for myndighedsbaseret arbejdsmarkedsprøvning som i Norge, men et nyt lovforslag, som kan træde i kraft i 2011, hvis det vedtages, vil efter svensk forbillede overlade arbejdsmarkedsprøvningen til arbejdsgiverne. Herefter er det således arbejdsgiverne, som skal sikre, at national og EU/EØS-arbejdskraft rekrutteres før udenlandsk arbejdskraft, og dokumentere, at ordnede løn- og arbejdsforhold er gældende i et konkret arbejdstilbud til udenlandsk arbejdskraft. I Danmark derimod har man udviklet arbejdsmarkedsbalancemodellen, der ved at samkøre en lang række data, blandt andet om virksomhedernes rekrutteringsbehov, giver viden om, hvor der er særlig mangel på arbejdskraft, hvorefter særlig nem adgang kan gives i den udstrækning, modellen vurderer, at der er behov for det. Samtidig høres arbejdsmarkedets parter i forhold til justering af visse andre af adgangskriterierne og om løn og arbejdsforhold i enkelte sager. I forhold til metode til sikring af den nationale/EU/EØSbeskæftigelse må Sverige altså siges at være det land, som er gået længst i forhold til en forenkling af reglerne vedrørende arbejdsmarkedsprøvning. Her overlades ansvaret for styringen af rekrutteringen af udenlandsk arbejdskraft primært til virksomhederne. Finland bevæger sig i samme retning på dette område. Også Norge og Danmark har indført praksis, der sætter virksomhedernes efterspørgsel i centrum for rekrutteringen, dog er Danmark gået længere end Norge i forhold til at forenkle metoder til at vurdere arbejdskraftbehovet. I Norge har man fortsat arbejdsmarkedsprøvning ved myndighed på nær den særlige kvote på 5000 specialister og faglærte.

Vender man blikket mod den måde, hvorpå de nordiske lande afgrænser adgangen til deres nationale arbejdsmarkeder, giver langt de fleste af landene kun ansøgere fra tredjelande adgang til ét bestemt job. Kun i Finland og Danmark gives der bredere adgang til henholdsvis en given branche eller til hele arbejdsmarkedet som sådan. Danmark er således det land, der som det eneste har åbnet til hele arbejdsmarkedet ved at indføre Greencard-ordningen, der giver mulighed for, at arbejdskraft fra tredjelande kan tilbyde deres arbejdskraft på det danske arbejdsmarked uafhængigt af et konkret jobtilbud. Adgangskriterier via denne ordning sikrer stadig en skarp kontrol med kvalifikationer og uddannelsesniveau. Imidlertid medfører denne ordning nogle nye udfordringer for et andet grundliggende adgangskrav, som alle de nordiske lande har til fælles, nemlig at løn og arbejdsforhold skal være normale i forhold til regler og overenskomster på det nationale arbejdsmarked. Ved kun at give adgang til arbejdskraft fra tredjelande til et konkret jobtilbud, som skal dukumenteres over for myndigheder og faglige organisationer, sikrer man en relativ nem kontrol med løn og arbejdsforhold. Så snart man åbner bredere

${ }^{228}$ Arbejdsgiverne er dog stadig forpligtede til at annoncere et job nationalt og via Eures i min. 10 dage ved nyrekrutteringer, inden arbejdskraft fra tredjelande kan rekrutteres. Endvidere bør arbejdsgiveren indhente tilkendegivelse fra lønmodtagerorganisationerne om arbejdsvilkår. Hvis de ikke gør dette, er det Migrationsverkets opgave. 
for hele eller dele af arbejdsmarkedet, overlades denne sikring af løn og arbejdsvilkår imidlertid til den almindelige arbejdsmarkedskontrol ved myndighed eller arbejdsmarkedets parter, alt efter hvordan det nationale arbejdsmarked er indrettet. Selvom man i Sverige udelukkende giver adgang på baggrund af et konkret jobtilbud, har det været diskuteret om arbejdsmarkedsprøvningen ved virksomhederne er tilstrækkeligt til at sikre, at fagforeninger høres omkring konkrete løn- og arbejdsvilkår. Endelig skal det også tilføjes at opholds- og arbejdstilladelser til udenlandsk arbejdskraft fra tredjelande altid i udgangspunktet er tidsbegrænset i alle de nordiske lande. Så selvom man får adgang til hele eller dele af arbejdsmarkedet er der altså altid en begrænsning i tidsrum for ophold. ${ }^{229}$

I alle de nordiske lande har man gennemført en eller anden form for lempelse i forhold til særlig kvalificeret arbejdskraft i perioden fra 2006-2008. Disse lempelser går primært på at lette ansøgningsmulighederne, således at bestemte grupper kan få særlig nem adgang. I Danmark har man indført „fast track“-ordninger såsom positivlisten og beløbsordningen, der fleksibelt kan justeres til at åbne op for særlige grupper af kvalificeret arbejdskraft. I nogle perioder kan det være arbejdskraft med minimum bachelorniveau i uddannelse inden for særlige arbejdsområder, mens det i andre perioder kan justeres i forhold til forandringer i arbejdskraftbehovet. Justeringerne kræver ikke lovændringer, og det er arbejdsgivernes efterspørgsel efter arbejdskraft, der primært driver justeringerne. I Norge vil man ved ikrafttrædelsen af den nye lovgivning i 2010 via egen „fast track“-ordning lette adgangen for både faglærte og specialister, og som sådan er forståelsen af kvalificeret arbejdskraft noget bredere end i Danmark. Opholdstilladelse til specialister er som den danske beløbsordning baseret på et konkret jobtilbud med et vist lønniveau, og på samme måde som i Danmark vil man kunne justere ordningerne fleksibelt uden lovændring. I Finland har man ikke bestemmelser omkring uddannelsesniveau, men derimod har man haft særlige adgangsbestemmelser for meget få specifikke grupper såsom forskere og ledergrupper, samt en særlig specialistarbejdstilladelse, som man også har det i Island, til at udføre en afgrænset opgave. Dette ændres dog muligvis, såfremt den ovenfor nævnte justering af adgangsreglerne efter svensk forbillede vedtages, hvorefter al udenlandsk arbejdskraft fra tredjelande, der kommer til Finland for at arbejde, skal søge om samme type opholdstilladelse på baggrund af et konkret jobtilbud. Sveriges regelværk fra slutningen af 2008 har hidtil adskilt sig væsentligt fra de andre nordiske lande. I Sverige har man gennemført en forenkling af reglerne og valgt ikke at lave særlige adgangsordninger for kvalificeret arbejdskraft. Derimod skal reglerne sikre nem adgang for den arbejdskraft, virksomhederne ønsker at rekruttere. I forhold til de forskellige landes evne til at facilitere arbejdsgivernes efterspørgsel efter arbejdskraft må man sige, at reglerne i samtlige lande i en vis udstrækning giver mulighed for tilpasning hertil. Komparativt er det dog Sverige, Danmark og Norge, der i

\footnotetext{
${ }^{229}$ Der kan som regel søges om forlængelse og efter en årrække også om permanent ophold, såfremt visse kriterier er opfyldt, procedurerne herfor varierer - se de enkelte landekapitler for mere information.
} 
forhold til adgangsbestemmelser hidtil mest entydigt kan karakteriseres ved en efterspørgselsdrevet rekrutteringspolitik, der favoriserer virksomhedernes formulerede behov for arbejdskraft. Finland lader dog til at være ved at bevæge sig i samme retning, såfremt det seneste forslag til regelforenkling vedtages.

Det er væsentligt at nævne, at de forskellige former for arbejdsmarkedsprøvning og de forskellige former for kontrol af uddannelsesniveau ved ansøgning $\mathrm{i}$ alle de nordiske lande har voldt problemer i forhold til at sikre en kort sagsbehandlingstid. I Danmark, hvor uddannelsesbaggrund i visse af de særlige adgangsordninger for udenlandsk arbejdskraft fra tredjelande spiller en stor rolle, har det vist sig tidskrævende at få sagerne ordentlig oplyst og materialet verificeret således, at man kan behandle de enkelte sager. I Norge har man oplevet nogle af de samme problemer med at sikre dokumentation og overholde servicemål for sagsbehandlingen, når man får mange ansøgninger. Metoden til arbejdsmarkedsprøvning kan også volde problemer, som det har været tilfældet i Finland og Island, hvor arbejdsgivere har ment, at behandlingen ved arbejds- og beskæftigelsesformidlingerne og fagforeningernes høring forlængede sagsbehandlingstiden unødvendigt. At sikre en rimelig smidig sagsbehandling samtidig med, at man sikrer, 1) at den nationale arbejdskraft bruges først, 2) at den udenlandske arbejdskraft får reelle løn- og arbejdsvilkår og 3) at ansøgernes kvalifikationer er de efterspurgte, er således en af arbejdsindvandringspolitikkens helt store udfordringer.

\subsection{Strategi}

Når man sammenligner regler og lovgivning, beskriver man indirekte politiske målsætninger og strategier. En egentlig sammenligning af den politiske rekrutteringsstrategi må dog inkludere mere end et fokus på det adgangsgivende regelværk. Her må man også betragte, hvilke aktører der er involveret i rekruttering, om der afsættes ressourcer, og om der foregår særlig institutionsbygning i form af for eksempel arbejdsformidlingsbureauer, professionalisering og rådgivning til rekruttering og i så fald, hvordan denne er udformet. Alle de nordiske lande har som sagt foretaget justeringer i deres regler med henblik på at lempe adgangen for kvalificeret udenlandsk arbejdskraft fra tredjelande til deres arbejdsmarkeder, og udviklingen har primært været efterspørgselsdrevet. Forstået på den måde, at det primært er arbejdsgivernes behov, der driver, hvilke migranter der søges selekteret via den nationale lovgivning om opholds- og arbejdstilladelse. Der er dog noget større forskelle at finde i institutionsbygningen til rekruttering mellem de forskellige nordiske lande.

Alle landene indgår i det fælleseuropæiske EURES-samarbejde og deltager hermed i den aktive formidling af international arbejdskraft internt i EU og EØS. EURES er samtidig det mest institutionaliserede sam- 
arbejde mellem de forskellige nordiske lande. Imidlertid har man i Danmark foretaget en yderligere institutionsbygning til at understøtte rekrutteringsprocessen omkring arbejdskraft fra tredjelande. De danske Work in Denmark-centre rummer således EURES, men har også til opgave at formidle anden udenlandsk arbejdskraft fra tredjelande og bistå virksomheder i forskellige rekrutteringsaktiviteter. Udviklingen i rekrutteringsstrategi i Danmark skiller sig i det hele taget noget ud fra de andre nordiske lande.

Danmark har som det eneste land hidtil udviklet en egentlig strategi i praksis omkring aktiv rekruttering og markedsføring af Danmark i udlandet og blandt andet oprettet et Work in Denmark-center i Indien. De nye tiltag, hvoraf de fleste er kommet til i 2008, har langt hen ad vejen været drevet af ønsker fra arbejdsmarkedsorganisationerne. Særligt har der været en alliance mellem arbejdsgiverorganisationerne og enkelte akademikerorganisationer såsom den danske ingeniørforening, mens LO-forbundene har været mere skeptiske i forhold til rekrutteringsstrategien. Lignende konstellationer mellem organisationer har forekommet i Sverige, Norge og Finland, ${ }^{230}$ hvor særligt arbejdsgiverorganisationerne har leveret støtte til reformer af arbejdsindvandringspolitikken. Imidlertid har aktiviteten i Danmark været større blandt organisationerne, og de har afsat egne midler til rekrutteringsinitiativer og -projekter. I Sverige, Norge og Finland har langt det meste af rekrutteringen derimod foregået på virksomhedsniveau. Det skal dog understreges, at myndighederne i Finland har udtalt, at de fremover ønsker at markedsføre Finland som et attraktivt arbejdsmarked i udlandet via de finske ambassader, og Sverige er også så småt på vej til at udvikle en mere aktiv rekrutteringsstrategi. I 2009 er den statslige myndighed Svenska Institutet således påbegyndt arbejdet med at udvikle en markedsføringsstrategi af Sverige over for udenlandsk arbejdskraft. ${ }^{231}$

En mulig forklaring på den hidtidige forskellighed i organisationernes investering i rekruttering kan være forskellige traditioner for ansvarsfordeling mellem virksomheds- og organisationsniveau i de nordiske lande. En anden mulig forklaring er, at denne forskellighed kan være forbundet med forskelle i erhvervsstruktur landene imellem, hvor Danmark er kendetegnet ved mange små og mellemstore virksomheder, som måske selv kan have svært ved at markedsføre sig over for udenlandsk arbejdskraft. Her skal det dog bemærkes, at Norge også har mange små og mellemstore virksomheder, uden at organisationerne dog har været lige så aktive som i Danmark, mens Sverige og Finland, som er kendetegnet ved store virksomheder, som sagt er påbegyndt udvikling af en mere aktiv rekrutteringsstrategi på myndighedsniveau.

\footnotetext{
${ }^{230}$ Dette kan sandsynligvis forklares med, at der generelt set har været mangel på ingeniører i de forskellige nordiske lande, og konkurrencen i forhold til den nationale arbejdskraft har været minimal. Se også Cerna (2009)

${ }^{231}$ I december 2009 præsenteredes webportalen www.workinginsweden.se, som er udviklet af Svenska Institutet
} 
Et andet element, som kan have spillet en rolle for den særlige udvikling i Danmark, er det politiske klima omkring indvandring generelt, der i Danmark siden 2001 har efterladt relativt begrænsede muligheder for at lette adgangen til det danske arbejdsmarked for tredjelandsborgere. Dette kan også have haft indflydelse på, at Danmark har fulgt en noget anden politisk strategi end for eksempel Sverige, der i højere grad har valgt at liberalisere adgangsreglerne. Dog er det bemærkelsesværdigt, at man alene i Danmark har indført en Greencard-ordning, som jo netop giver adgang uden konkret jobtilbud. Det skal nu igen understreges, at ordningen er temmelig restriktiv og stiller store krav til kvalifikationer. Hele rationalet for at kunne åbne op for udenlandsk arbejdskraft fra tredjelande i Danmark er, at der skal være tale om særlig kvalificerede grupper eller særlige løngrupper. I Sverige derimod har den politiske diskussion omkring arbejdskraft fra tredjelande haft fokus på regelforenkling og derved at kunne skabe et mere effektivt og fleksibelt system for arbejdsindvandring. Et særtræk ved Sveriges lovgivning er, at den gør det muligt for asylansøgere, som har fået afslag, at skifte spor til at søge om opholds- og arbejdstilladelse uden at forlade landet, såfremt de har haft fast ansættelse i Sverige i mindst seks måneder. Finland bevæger sig i visse henseender i samme retning som Sverige, ved at ønske regelforenkling og afvikling af den myndighedsbaserede arbejdsmarkedsprøvning, dog uden samme fleksibilitet vedrørende asylpolitik. I Norge har man en strategi, som både har fokus på at sikre særlig kvalificeret arbejdskraft samtidig med, at man forsøger at forenkle ansøgningsprocedurerne, således at rekrutteringen bliver nemmere for arbejdsgivere. I Norge har virksomhederne igennem de seneste år i høj grad benyttet sig af faglært og ufaglært arbejdskraft fra andre EU-lande. Denne erfaring har givetvis medført en mere positiv indstilling i forhold til at inkludere den faglærte arbejdskraft i ordningerne, som letter adgangen til det norske arbejdsmarked.

Set i lyset af den fælles platform omkring efterspørgselsdrevet rekrutteringspolitik og den generelle enighed om, at der vil være behov for at rekruttere arbejdskraft i udlandet fremover, kunne man forestille sig, at der netop omkring markedsføring af de nordiske arbejdsmarkeder vil være mulighed for et fælles nordisk eller europæisk samarbejde. Og myndighederne i Norden har lavet en række fælles samarbejder for at koordinere og styrke rekrutteringen af udenlandsk arbejdskraft. De danske myndigheder har fx. oplevet, at myndighederne i Norge har været meget offensive og målrettede $\mathrm{i}$ deres rekruttering og dermed ganske dygtige til at få fat i udenlandske arbejdstagere. Den danske Arbejdsmarkedsstyrelse har på den baggrund været på studiebesøg i Norge, ligesom Norge har besøgt Danmark. Det primære fokus har været at undersøge, hvordan Norge har indrettet deres EURES-system. I Norge er indsatsen spredt ud til alle de lokale arbejdsmarkedsformidlinger, hvilket de har oplevet som sårbart, fordi $1 / 2-1$ medarbejder sidder alene med opgaven om udenlandsk arbejdskraft, hvorfor det er svært at målrette indsatsen. 
Blandt andet på baggrund af disse erfaringer besluttede man i Danmark at danne de tre større Work in Denmark-enheder i København, Århus og Odense og dermed koncentrere den opsamlede viden og indsats. Et andet myndighedssamarbejde går igennem „Den Nordiske Samrådsgruppe på Højt Niveau for Flygtningespørgsmål“, hvor integrationsministrene fra de forskellige nordiske lande mødes. For nylig har man udarbejdet en fælles nordisk faktuel rapport, der klarlægger og sammenligner de udlændingeretlige regler for arbejdskraftindvandring med fokus på kvalificeret arbejdskraft. ${ }^{232}$ Danmark og Sverige har også et igangværende samarbejde i form af CrossBorder-Øresund, der er et EURES-samarbejde i Øresundsregionen. I forhold til rekruttering har der været tale om en fælles markedsføring af arbejdspladser i den skandinaviske sundhedssektor, men ideen er efterfølgende blevet droppet igen. Man oplevede, at der på trods af mange ligheder var for mange forskelle, når man i samme kampagne skulle brande en lille by i Sverige og hovedstaden København. Projektet var tiltænkt alle nationaliteter og altså ikke kun tredjelandsborgere. Endeligt har man mellem de skandinaviske og baltiske lande opbygget en online Toolbox med information til arbejdstagere fra tredjelande. Toolbox’en skal gøres tilgængelig på EU’s EURES-portal.

Nordisk samarbejde omkring rekruttering af kvalificeret arbejdskraft opfattes generelt positivt af myndigheder og arbejdsmarkedets parter. Da den samlede mængde kvalificeret arbejdskraft, der skal bruges i Danmark, Norge, Sverige, Finland og Island er begrænset, giver det ikke meget mening at tale om et egentligt konkurrenceforhold mellem de nordiske lande. I de fleste nordiske lande - og her særligt blandt arbejdsgivere - har man imidlertid større fokus på et styrket fælleseuropæisk samarbejde frem for et nordisk. Dette kan både skyldes et ønske om at harmonisere regler i forhold til at lette arbejdskraftens mobilitet internt i EU og et ønske om at være en del af en samlet markedsføring af Europa frem for Norden i forhold til udenlandsk arbejdskraft fra tredjelande. Det skal dog bemærkes, at særligt Norge har tilkendegivet, at man ikke umiddelbart er interesseret i ordninger a la det danske Greencard eller det europæiske Blue Card, da man anser dette for at være for fokuseret på udbud frem for efterspørgsel. I Danmark har man blandt arbejdsmarkedsorganisationerne heller ikke været begejstret for måden, Blue Card-ordningen er skruet sammen på, da den ikke stemmer godt overens med det danske arbejdsmarkedssystem, hvor løn reguleres ved overenskomst. Dette vidner om stærke nationale traditioner for regulering af arbejdsmarkederne, som vanskeliggør udviklingen af fælles strategier i forhold til at rekruttere udenlandsk arbejdskraft fra tredjelande.

\footnotetext{
${ }^{232}$ Ministeriet for Flygtninge, Indvandrere og Integration, Erhvervsenheden (2009), Faktuel rapport om de nordiske landes udlændingeretlige regler vedrørende arbejdskraftsindvandring med fokus på højt kvalificeret udenlandsk arbejdskraft, udarbejdet af arbejdsgruppen om arbejdskraftsindvandring for Den Nordiske Samrådsgruppe på Højt Niveau for Flygtningespørgsmål. 10. juni 2009
} 


\subsection{Realiteter}

Betragter man tilgangen af udenlandsk arbejdskraft til Danmark, Sverige, Norge og Finland uafhængigt af oprindelsesland, adgangstype og kvalifikationer, har stort set alle lande oplevet en væsentlig tilgang af arbejdskraft siden 2003. En tendens, der også er gældende for arbejdskraft alene fra tredjelande, og som er fortsat ind i 2009. Ifølge tilgangstallene i Island for 2008 og 2009 er dette det eneste nordiske land, som har oplevet en egentlig nedgang i tilgangen af udenlandsk arbejdskraft i 2008 som følge af de særlige samfundsøkonomiske udfordringer, som Island har stået over for i forbindelse med finanskrisen.

Norge har oplevet den største tilgang af udenlandsk arbejdskraft, og også tilgangen fra tredjelande er steget væsentlig fra omkring 2.800 udstedte arbejdstilladelser i år 2000 til 12.300 i 2008. I Danmark har man også oplevet en stigning i tilgangen, men samlet set udstedte man langt færre opholds- og arbejdstilladelser til borgere fra tredjelande end i Norge. Derimod har tilgangen været relativ stor til Sverige. I 2008 udstedte man således 14.513 opholdstilladelser til personer fra tredjelande i Sverige. ${ }^{233}$ For alle lande gælder det, at en langt mindre del af de udstedte opholds- og arbejdstilladelser er gået til særlig kvalificeret arbejdskraft fra tredjelande. Langt størstedelen af den kvalificerede arbejdskraft kommer fra Asien og her primært Indien eller Kina. I Norge modtager man også en stor del af den kvalificerede arbejdskraft fra Rusland, mens Finland modtager en del fra Ukraine. I 2008 fik 3.384 personer adgang via faglært/specialist-kategorien i Norge, mens man i Danmark udstedte 2.624 opholds- og arbejdstilladelser til særligt kvalificerede, som fik adgang via de nye „fast track“-ordninger for kvalificeret arbejdskraft. Og tilgangen på disse ordninger er stigende. ${ }^{234}$

En anden måde at sammenligne på er ved at se på adgangstal udelukkende for ingeniører. Da der i flere af landene ikke findes registrering af tilgang af arbejdskraft fra tredjelande fordelt på kompetencebaggrund, er det kun muligt at sammenligne Danmark og Sverige. Ved sammenligning af tal fra disse to lande fremgår det dog klart, at Sverige har givet opholds- og arbejdstilladelse til langt flere ingeniører igennem 2008 (se nedenstående oversigtsboks med tal over antal rekrutterede ingeniører til de nordiske lande).

\footnotetext{
${ }^{233}$ Disse tal er ikke direkte komparative, og man skal være opmærksom på, at der i Sverige opgøres på opholdstilladelser, mens tallene for Danmark og Norge er både opholds- og arbejdstilladelser. Tallene for Norge og Sverige inkluderer også personer, som ikke nødvendigvis er ankommet som arbejdskraft, men som dog har opnået opholdstilladelse på baggrund af deres arbejdsmarkedstilknytning. Se landekapitlerne for kilder til de enkelte tal.

${ }^{234}$ Se landekapitlerne for kilder til de enkelte tal.
} 
Oversigtsboks over antal rekrutterede ingeniører

\begin{tabular}{lr}
\hline Land & Tilgang af ingeniører fra tredjelande $\mathbf{~} \mathbf{~ 2 0 0 8}^{235}$ \\
\hline Danmark & 337 \\
Sverige & 1272 \\
Norge & - \\
Finland & - \\
Island & 53 \\
\hline
\end{tabular}

En tidligere sammenligning af tilgangen af kvalificeret arbejdskraft fra udlandet til henholdsvis Danmark og Sverige viste, at landene allerede tilbage i 1999 adskilte sig i deres evne til at tiltrække kvalificeret arbejdskraft - også set i forhold til arbejdsstyrkens størrelse. Sverige har således i en længere periode relativt set været bedre til at tiltrække veluddannet arbejdskraft fra tredjelande. ${ }^{236}$ Hvorvidt Sverige vil øge forspringet yderligere på baggrund af de seneste forandringer i adgangsregler, vil det dog tage en række år, før man reelt kan evaluere.

Oversigtsboks over den generelle ledighed i de nordiske lande ${ }^{237}$

\begin{tabular}{lrr}
\hline Land & $\mathbf{2 0 0 8}$ & 2009 (3. kvartal) \\
\hline Danmark & $3,3 \%$ & $6,0 \%$ \\
Sverige & $6,2 \%$ & $8,3 \%$ \\
Norge & $2,5 \%$ & $3,1 \%$ \\
Finland & $6,4 \%$ & $8,2 \%$ \\
Island & $3 \%$ & $7,2 \%$ \\
\hline
\end{tabular}

Ledigheden har i løbet af højkonjunkturen ligget meget lavt i Norge, Island og Danmark, men som følge af den internationale finanskrise har alle de nordiske lande fra slutningen af 2008 og frem oplevet, at den generelle ledighed er stigende og arbejdskraftbehovet faldende. Ser man isoleret på ledigheden blandt ingeniører, har denne generelt været meget lav på tværs af de nordiske lande. I gennemsnit lå ledigheden i 2008 blandt ingeniører på 2 \% eller derunder i stort set alle de nordiske lande undtagen Finland, hvor ledigheden blandt ingeniører fra de polytekniske højskoler nåede op på 3,4 \%. Særligt i Norge, Danmark og Island har man under højkonjunkturen manglet ingeniører inden for visse brancher. Den finansielle krise har på kort sigt ændret noget på dette, således at ingen lande længere melder om generel arbejdskraftmangel. Ledigheden blandt ingeniører er også steget $\mathrm{i}$ alle de nordiske lande. I Sverige og Norge lå ledigheden blandt ingeniører stadig under 2 \% i sommeren 2009, mens den i Danmark og Finland ligger på gennemsnitlig mellem 4-5\% varierende for, hvilke grupper af ingeniører man betragter. I Island har man oplevet endnu mere markante

\footnotetext{
${ }^{235}$ For data se de enkelte landekapitler i denne rapport. Det har ikke været muligt at skaffe tal for tilgang af ingeniører i 2008 til Norge og Finland.

${ }^{236}$ Nyt fra Rockwool Fondens Forskningsenhed Juni 2009

${ }^{237}$ Kilde: OECD, The OECD Main Economic Indicators. Harmonized Unemployment rate (HUR)
} 
stigninger i ledigheden blandt ingeniører. I 2009 har ledigheden for civilingeniører for eksempel ligget et sted mellem 5,2-6,7 \%. ${ }^{238}$

På længere sigt - og her regnes der ca. 5-10 år ud i fremtiden - vurderer alle de nordiske lande dog, at man vil opleve en vis mangel på ingeniørarbejdskraft - en mangel, som sandsynligvis kun vil øges med tiden som følge af den demografiske udfordring i forhold til en aldrende befolkning. ${ }^{239}$ Hvor stor denne mangel reelt vil blive, og hvordan manglen kan imødekommes, er der dog temmelig forskellige bud på.

Grundet omfanget af den aktuelle økonomiske krise i Island er tidshorisonten på en øget efterspørgsel efter ingeniører sandsynligvis noget længere end i de andre nordiske lande. I Sverige vurderer Högskolaverket (den nationale styrelse for højere uddannelse), at fra og med år 2010 vil manglen på ingeniører stige med omkring 1000 personer pr. år, da for få unge starter på uddannelsen. Andre aktører har peget på, at denne mangel ikke vil inkludere civilingeniører, som derimod vil være i overskud, mens ingeniører vil mangle på en række specialområder. I Norge, som i Danmark og Finland, er man ligeledes opmærksomme på, at manglen på ingeniører ikke handler om volumen, men snarere om at kunne uddanne eller tiltrække særlige specialister. Af diskussionerne i Sverige, Norge og Finland fremgår det, at man mener, at en del af behovet vil kunne løses ved at uddanne flere ingeniører nationalt og forbedre ingeniøruddannelserne. Hvor stor en del er det dog svært at vurdere. I Norge ser man også rekruttering af udenlandske ph.d.-studerende som en del af løsningen. Anderledes har Ingeniørforeningen i Danmark længe haft manglen på ingeniører som en af sine mærkesager, og der er sat tal på fremtidens behov, men her er åbning af det danske arbejdsmarked mere i fokus. Allerede i 2015 forventer ingeniørforeningen således, at Danmark vil mangle 7600 ingeniører. ${ }^{240}$ At sikre normering, antallet af studerende på ingeniøruddannelserne og forbedre uddannelseskvalitet ligger også den danske ingeniørorganisation på sinde, men rekruttering af udenlandsk arbejdskraft anses også som en nødvendighed for at kunne imødekomme den fremtidige mangel på ingeniører samt for at få adgang til højt specialiserede kompetencer, der kan fremtidssikre dansk erhvervsliv.

Vurderinger af arbejdskraftbehov er altid forbundet med en vis usikkerhed. Udviklingen i den internationale økonomi, teknologi, in- og outsourcing, off-shoring, erhvervsmønstre, uddannelsesstruktur mv. vil påvirke arbejdskraftbehovet. Fælles for de nordiske lande er dog, at den

\footnotetext{
${ }^{238}$ Kilder: Danmark: Nøgletal fra Ingeniørernes Arbejdsløshedskasse (IAK) www.iak.dk, oktober 2009, Norge: Arbeids- og velfærdsdirectoratet, statistik og utredning. Månedsstatistik august 2009, Sverige: Tal for Sveriges Ingeniørs medlemmer af Akademikernas Erkända Arbetslöshetskassa august 2009. Finland: Statistik fra TEK, baseret på data fra Arbejds- og Erhvervsministeriet: Det skal bemærkes, at gruppen af civilingeniører og arkitekter havde en lavere ledighed på henholdsvis 2 \% i 2008 og 2,9 \% i november 2009. Island: Tal for perioden januar 2008 til november 2009 fra det islandske Arbejdsdirektorat og fra Forbundet for Civilingenioørernes (SV) og Forbundet for Højskoleingeniørernes (TFÍ) medlemsregistre. I Island har civilingeniører haft en noget højere arbejdsløshed end højskoleingeniører begge år - dog på maksimalt 6,7 \% i 2009.

${ }^{239}$ EU Commission (2007)

${ }^{240}$ IDA, juni 2009
} 
teknologiske udvikling i ingeniørbranchen går mod en stadig større specialisering, og at der således på længere sigt sandsynligvis vil være behov for særlige kompetencer, som man måske ikke uddanner til i de enkelte nordiske lande. Hvordan man vælger at løse denne udfordring, kræver dels, at man vurderer, hvilke kompetencer man mangler, og hvorvidt man nationalt er i stand til at uddanne den fornødne arbejdskraft, dels, at man forholder sig til, hvem der skal bære investeringerne i en eventuel rekruttering af arbejdskraft fra udlandet. I Sverige er investeringerne i international rekruttering lagt ud til de enkelte virksomheder, som jo også kan gøre brug af professionelle rekrutteringsvirksomheder. I Danmark derimod bæres i dag en større og større del af investeringerne af det offentlige i kraft af den institutionsbygning, som er foretaget til at understøtte den aktive rekrutteringsstrategi. Denne forskel mellem Danmark og Sverige kan ses i sammenhæng med forskellene i erhvervsstruktur; det vil sige en dansk tilgang, hvor man forsøger at skabe rekrutteringsmuligheder for mindre og mellemstore virksomheder, der kan have vanskeligt ved på egen hånd at gennemføre en systematisk international rekruttering og en svensk tilgang, hvor man har større tradition for store internationaliserede virksomheder, der kan skabe opmærksomhed om svensk arbejdsmarked.i udlandet og gennemføre international rekruttering.

\subsection{Regler, strategier og realiteter - en opsummering}

Opsummerende skal det understreges, at trods udvidelsen af EU og dermed adgangen for nordiske virksomheder til at rekruttere også kvalificeret arbejdskraft i Østeuropa, så har alle de nordiske lande vedtaget ny lovgivning og dermed iværksat nye strategier, der lemper adgangen for kvalificeret arbejdskraft fra tredjelande. De forventede demografiske ændringer og den deraf følgende mangel på (kvalificeret) arbejdskraft er en af hovedforklaringerne bag denne udvikling. Paradoksalt nok er dette sket lige op til finanskrisens udbrud og den efterfølgende stigende ledighed. Det ændrer dog ikke ved de udfordringer, de demografiske forandringer skaber på sigt.

Reglerne for opholds- og arbejdstilladelse er indrettet forskelligt i de enkelte nordiske lande. Det er sket på baggrund af forskellige strategiske overvejelser og forskellige reguleringstraditioner. Dog bygger reguleringen på tværs af de nordiske grænser på de samme grundlæggende principper. Lovgivningen på området i de forskellige lande balancerer således alle mellem 1) at facilitere arbejdsgivernes efterspørgsel efter arbejdskraft og 2) at beskytte det nationale og europæiske arbejdsmarked mod dumping af løn og arbejdsvilkår.

Af væsentlige forskelle skal nævnes, at man i Sverige har haft fokus på regelforenkling. Det er nu virksomhederne, der har hovedansvaret for at bedømme, om der er mangel på arbejdskraft på et givent område, og om 
der skal rekrutteres udenlandsk arbejdskraft til en given stilling. Finland er efter svensk forbillede ligeledes ved at afskaffe den myndighedsbaserede arbejdsmarkedsprøvning, såfremt de nye regler vedtages og træder i kraft i 2011. I Danmark har man derimod valgt at lave en række scrordninger, der via lønniveau eller særlige kompetencer giver adgang til det danske jobmarked. Umiddelbart kunne det se ud som om, Sverige er gået længst i liberaliseringen af adgangen for udenlandsk arbejdskraft, men ser man på Danmarks Greencard-ordning, som giver adgang for jobsøgere til hele det danske arbejdsmarked uden et konkret jobtilbud, må man sige, at Danmark også har taget skridt i retning af en form for liberalisering. I Norge er man derimod ikke interesseret i ordninger a la det danske Greencard, da man ikke mener, at ordningen er efterspørgselsorienteret nok. Norges regler giver således - ligesom de svenske - udelukkende adgang for arbejdskraft fra tredjelande med et konkret jobtilbud, men med udgangspunkt i de gode erfaringer, Norge har haft med udenlandsk arbejdskraft primært fra EU, er forståelsen af kvalificeret arbejdskraft noget bredere end i Danmark og inkluderer også grupper af faglærte.

De valgte strategier i forhold til at implementere reguleringen vedrørende højtuddannede fra tredjelande afhænger af en række forhold, hvor bl.a. den nationale erhvervsstruktur fremstår som betydningsfuld. De statslige myndigheder er tilsyneladende i højere grad involveret i iværksættelse og varetagelse af rekrutteringen i Danmark, end hvad vi finder i de øvrige nordiske lande. Manglen på store koncerner med vidtforgrenede internationale aktiviteter og kontakter kan delvist forklare det mere omfattende myndighedsengagement i Danmark. Reelt foretages en del af den aktive rekruttering imidlertid stadig på virksomhedsniveau også i Danmark, men tiden vil vise, om myndighedsinitiativerne får den ønskede effekt på længere sigt. Det er muligt, at mindre og mellemstore virksomheder i de øvrige nordiske lande fortsat kan lukrere på de store virksomheders markedsføringseffekt i udlandet, men også i Sverige og Finland er man påbegyndt markedsføringstiltag til at støtte op om rekruttering i tredjelande på myndighedsniveau.

Ser vi på, hvor mange højtkvalificerede personer der er kommet til de nordiske lande fra tredjelande - realiteterne - er tallene stigende, men stadig forholdsvis beskedne. De, som er kommet, er primært kommet fra Asien og her særligt Kina og Indien. Det ligger i sagens natur, at de nye regler tager sigte på de kommende års mangel på kvalificeret arbejdskraft. Spørgsmålet er, om det på sigt vil lykkes at tiltrække den relevante arbejdskraft. Herunder bliver det ikke mindst en udfordring at tilpasse arbejdsindvandringen i forhold til de specifikke behov; visse arbejdskraftbehov kan forudses, men nye forskydninger i den globale arbejdsdeling, teknologiske nybrud og pludselige økonomiske kriser er alle forhold, der i et vist omfang gør det umuligt at forudse det fremtidige arbejdskraftbehov. 


\subsection{Andre perspektiver på arbejdsindvandringspolitik}

Analysen af regler, strategier og realiteter giver et billede af formelle og faktiske ligheder og forskelle i regulering og tiltag over for kvalificeret arbejdskraft fra tredjelande. Vi får også delvist sammenlignelige tal på, hvor mange der er kommet til de nordiske lande. Men den komparative analyse kan ikke entydigt pege på, om bestemte politikker eller reguleringer i de enkelte nordiske lande har resulteret i, at flere eller færre personer med særlige kvalifikationer er ankommet fra tredjelande. Der er to umiddelbare forklaringer. For det første er tidshorisonten for nogle af de lempelser, som er foretaget med særligt henblik på kvalificeret arbejdskraft fra tredjelande, meget kort, og man har endnu ikke set gennemslagskraften af tiltagene. For det andet er der store forskelle i vurderingen af, hvad der kendetegner kvalificeret arbejdskraft, og hvordan adgangsreglerne er indrettet, og som følge heraf er registreringen forskellig og til tider mangelfuld. Dette gør det svært at sammenligne data for tilgangen af udenlandsk arbejdskraft landene imellem. På længere sigt har man også brug for komparative bestandstal for at kunne sige noget om, hvilke lande der er i stand til over tid at fastholde den kvalificerede arbejdskraft. Derudover er der også en række andre væsentlige faktorer for arbejdsindvandring såsom personlige netværk, økonomiske incitamentsforskelle og sprog, som endnu ikke er blevet behandlet i denne rapport. Som tidligere forskning har vist, har makrostrukturer stor indflydelse på, hvilket land en arbejdstager vælger at søge til.

Danmark og Norge har i særdeleshed haft stor succes med at tiltrække arbejdskraft fra andre EU-lande, hvilket ofte tilskrives den økonomiske opsvingsperiode frem til slutningen af 2008, hvor der i højere grad i disse to lande end i Sverige har været en stærk efterspørgsel efter arbejdskraft. ${ }^{241}$ Der var særligt tale om arbejdstagere fra Østeuropa, som altså først og fremmest søgte til Norge og Danmark på trods af, at Sverige ikke havde særlige overgangsregler for østeuropæiske arbejdsmigranter, sådan som det var tilfældet i Norge og Danmark. Dette kan tolkes som udtryk for, at det i højere grad er efterspørgslen efter arbejdskraft end den specifikke regulering på området, der er afgørende for, hvor mange udlændinge der søger arbejde. Set i relation til kvalificeret arbejdskraft fra tredjelande peger denne erfaring på, at reguleringen i de enkelte nordiske lande nok ikke vil have den store betydning for, hvor mange der kommer - virksomhedernes efterspørgsel efter arbejdskraft vil i højere grad bestemme dette. Reguleringen vil derimod have stor betydning for, hvor hurtigt/langsomt og mere eller mindre problemfyldt de administrative og praktiske processer forløber vedrørende godkendelse/afvisning af ansøgning om arbejdstilladelse. Omvendt kan det ikke afvises, at hvis mange udlændinge oplever, at det er vanskeligere at få de relevante tilladelser på plads i et nordisk land frem for et andet, så vil det også påvirke landevalg og dermed antal.

\footnotetext{
${ }^{241}$ Dølvik \& Eldring (2008)
} 
Oversigtsboks over skattebyrde og årlig bruttoindkomst $\mathrm{i}$ industri og service

\begin{tabular}{|c|c|c|}
\hline Land & Skattebyrde i \% - 2008 ${ }^{242}$ & $\begin{array}{r}\text { Årlig bruttoindkomst i industri og service } \\
\text { euro }-2006^{243}\end{array}$ \\
\hline Danmark & $38,9 \%$ & 48307,3 \\
\hline Sverige & $42,5 \%$ & 35084,0 \\
\hline Norge & $34,3 \%$ & 47221,4 \\
\hline Finland & $38,3 \%$ & 34080,0 \\
\hline Island & $23,7 \%$ & - \\
\hline
\end{tabular}

Sammenligner man lønniveau og skattebyrde, placerer Danmark og Norge sig relativt bedre end Sverige. Lav skat eller fleksibel skat er også faktorer, som ofte fremføres som vigtige økonomiske incitamenter til at øge arbejdsmigration. Tidligere studier har imidlertid konstateret, at skattetryk godt nok har en signifikant effekt på mobiliteten i arbejdskraften, men at effekten er relativt lille og ikke kan ses isoleret. Gode sociale forhold (børnepasning, sygesikring mv.), velfungerende infrastruktur ( $\mathrm{fx}$. lokal transport) spiller for eksempel også en rolle i den større sammenhæng, og her har alle de nordiske lande noget at byde på. ${ }^{244}$ Endvidere har sprog også en særlig betydning, hvor alle de nordiske lande jo repræsenterer små sprogområder og som sådan har lignende udfordringer i forhold til rekruttering af udenlandsk arbejdskraft.

Bemærkelsesværdigt er det dog som tidligere nævnt, at Sverige har været langt bedre til at tiltrække arbejdskraft fra tredjelande end Danmark. Ser man på lønniveauet i henholdsvis Sverige og Danmark, må det siges at være relativt bedre i Danmark. Dette har måske nok haft effekt på tiltrækningen af arbejdskraft fra andre EU-lande, men synes altså ikke at have effekt på tiltrækningen af udenlandsk arbejdskraft fra tredjelande. En umiddelbar forklaring herpå kan være den stramning af regelværket for adgang til Danmark fra tredjelande, som blev gennemført i 2002. Dette kan have fungeret som en barriere også for den kvalificerede arbejdskraft. Som tidligere nævnt har forskellen i tilgang af arbejdskraft fra tredjeland mellem de to lande dog gjort sig gældende i længere tid, end Danmark har ført en stram udlændingepolitik. På den baggrund er det relevant at overveje andre faktorer såsom sociale netværk, som tidligere international migrationsforskning har påpeget også har stor indflydelse på tendensen til arbejdsmigration. ${ }^{245}$

Den lille andel af rekrutteringer af arbejdskraft fra tredjelande til Danmark betyder, at nye grupper af arbejdstagere fra tredjelande sandsynligvis i mindre grad vil have netværk i Danmark inden ankomst. Hvorimod den større andel af udenlandske arbejdstagere fra tredjelande i Norge og Sverige naturligt vil betyde, at flere nye arbejdssøgere har netværk i disse lande. Sandsynligheden for gode netværk har tendens til at

\footnotetext{
${ }^{242}$ Kilde: Eurostat, Tax wedge on labour costs: The tax wedge on the labour cost measures the relative tax burden for an employed person with low earnings.

${ }^{243}$ Kilde: Eurostat, Average gross annual earnings in industry and services, by gender; Total (Of fulltime employees in enterprises with 10 or more employees (ECU/EUR)

${ }^{244}$ Liebig \& Sousa-Poza (2005)

${ }^{245}$ Massey (1987)
} 
øge nye arbejdstageres incitament til at søge til et givent land. Dette kan måske forklare en del af tendensen til, at Danmark hidtil har modtaget så relativt få kvalificerede personer fra tredjelande, selvom Danmark har klaret sig relativt godt i forhold til at tiltrække arbejdskraft fra EU-lande. I hvilken grad et land allerede har et etableret netværk for givne grupper af kvalificerede arbejdstagere fra tredjelande, kan således også være en af de store udfordringer, som de nordiske lande står over for i forhold til den politiske målsætning om at styre arbejdsmigrationen alt efter efterspørgslen efter arbejdskraft. Sagt med andre ord har migrationsprocesser en tendens til at få deres egne sociale dynamikker uafhængigt af formel lovgivning og regulering. ${ }^{246}$

Endelig er der en række problemstillinger, der i praksis har vist sig relevante i forbindelse med kvalificeret udenlandsk arbejdskraft, men som sjældent berøres i diskussioner af arbejdsindvandringspolitik målrettet $k v a-$ lificeret arbejdskraft. Igennem de seneste 30 år har det været bredt anerkendt, at immigration kan føre til segmentering af de nationale arbejdsmarkeder, hvor migrantgrupper primært ender i mindre prestigefyldte job med ringere løn og arbejdsvilkår. ${ }^{247}$ Et fænomen, som også kan gøre sig gældende i forhold til højtkvalificerede migrantgrupper. ${ }^{248}$ For det første som en konsekvens af, at det kan være svært at tilpasse lovgivning dynamisk i forhold til efterspørgslen efter arbejdskraft over tid - her bliver de forskellige nordiske metoder til bestemmelse af arbejdsmarkedsbehov særlig interessante at følge fremover. For det andet som en konsekvens af, at kompetencer ikke nødvendigvis anerkendes. ${ }^{249}$ I alle de nordiske landes regelværk skelnes der mellem adgang for asylansøgere og adgang for arbejdstagere fra tredjelande. Som nævnt er det kun i Sverige, at en asylansøger har mulighed for at skifte spor og søge om ophold som arbejdstager. Forskelssætningen mellem arbejdskraft og anden immigration kan imidlertid gøre det svært at anerkende faglige kompetencer blandt grupper, som ikke ankommer via de særlige ordninger for kvalificeret arbejdskraft. En tredje faktor, som man bør være opmærksom på, er, at opholdslængden ved opholdstilladelse altid som udgangspunkt er begrænset til en vis periode i alle de nordiske landes regelværk. Man kan hævde, at denne form for regulering i højere grad lægger op til arbejdskraftsmobilitet frem for egentlig migration. ${ }^{250}$ Den fleksibilitet, som arbejdskraftsmobilitet giver, kan tænkes at forebygge tidligere tiders integrationsproblemer og er måske også et udtryk for en ny måde at tænke integration, hvor det primært handler om at tilbyde sin professionelle kompetence i en periode frem for kulturel tilpasning eller assimilation. For at den udenlandske arbejdskraft kan klare sig godt på de nationale arbejdsmarkeder, må man dog klæde dem på til at kunne begå sig i regler og traditioner, og det kan være ressourcekrævende

\footnotetext{
${ }^{246}$ Ibid.

${ }^{247}$ Piore (1980), Massey et al. (1993), Reitz (2002)

${ }^{248}$ Lowell (2005)

${ }^{249}$ Peixoto (1999)

${ }^{250}$ Lowell (2005), OECD (2009) International Migration Outlook: Sopemi 2009
} 
for virksomheder og offentlige myndigheder. Et nyt fænomen i dansk arbejdsindvandringspolitik er således, at man i dag har fokus på, at myndigheder og virksomheder i samarbejde kan støtte op om og forbedre den sociale integration af den udenlandske arbejdskraft og medfølgende familie. Der er dog et iboende paradoks i, at det på den ene side er et mål i sig selv at forsøge at få den kvalificerede arbejdskraft til at blive i længere tid, samtidig med at adgangsordningerne giver tidsbegrænset arbejds- og opholdstilladelse. En vej ud af dette paradoks er at sikre en smidig og effektiv sagsbehandling, hvilket vil være en fortsat udfordring for myndigheder i de nordiske lande.

\section{Referencer}

Cerna, L. (2009): „The Varieties of highskilled immigration policies: coalitions and policy outputs in advanced industrial countries“ in Journal of European Public Policy 16(1): pp. 144-161

Dølvik, Jon Erik \& Line Eldring (2008): „Arbeidsmobilitet fra de nye EUlandene til Norden - Utviklingstrekk og konsekvenser“, Nordisk Ministerråd, 2008:502.

EU Commission (2007) „Europe’s Demographic Future: Facts and figures on Challenges and opportunities“, October

Eurostat (2008), Tax wedge on labour costs: The tax wedge on the labour cost measures the relative tax burden for an employed person with low earnings.

Eurostat (2006), Average gross annual earnings in industry and services, by gender; Total (Of full-time employees in enterprises with 10 or more employees (ECU/EUR)

IDA (2009): "Prognose for ingeniørmangel”, IDA Analyse juni 2009

Ministeriet for Flygtninge, Indvandrere og Integration, Erhvervsenheden (2009), Faktuel rapport om de nordiske landes udlændingeretlige regler vedrørende arbejdskraftsindvandring med fokus på højt kvalificeret udenlandsk arbejdskraft, udarbejdet af arbejdsgruppen om arbejdskraftsindvandring for Den Nordiske Samrådsgruppe på Højt Niveau for Flygtningespørgsmål. 10. juni 2009

Liebig, Thomas \& Alfonso Sousa-Poza (2005), Taxation, Ethnic Ties and the Location Choice of Highly Skilled Immigrants. OECD Social, employment grants. OECD Social, employment and Migration Working Papers 2005(3)

Lowell, B. Lindsay (2005) „Policies and Regulations for Managing Skilled International Migration for Work“ Paper presented for United Nations Expert Group Meeting on International Migration and Development, New York 6-8 july 2005, UN/POP/MIG/2005/03

Massey, Douglas S. (1987) „Understanding Mexican Migration to the United States“ American Journal of Sociology, 92(6), pp. 1372-1403

Massey, Douglas S, Joaquín Arango, Graeme Hugo, Ali Kouaouci, Adele Pellegrino and J. Edward Taylor (1993) „Theories of International Migration: A Review and Appraisal“. Population and Development Review. 19(3): 431-466

Nyt fra Rockwool Fondens Forskningsenhed Juni 2009

OECD (2008), The OECD Main Economic Indicators. Harmonized Unemployment rate (HUR)

OECD (2009) International Migration Outlook: Sopemi 2009

Peixoto, João (1999) „International Firms, National Managers: The Obstacles to Migration of Highly Skilled Labour in Trannational Corporations“.Paper presented to ESRI, Sept.21-24 1999, Copenhagen, Denmark

Piore, Michael J. (1980) „Birds of Passage: Migrant Labor and Industrial Societies“. Cambridge: Cambridge University

Pres 